U.S. GEOLOGICAL SURVEY

THE ORPHAN LODE MINE, GRAND CANYON, ARIZONA

A CASE HISTORY OF A MINERALIZED, COLLAPSE-BRECCIA PIPE

BY

WILLIAM L. CHENOWETH ${ }^{1}$

Open-File Report $86-510$

This report is preliminary and has not been reviewed for conformity with U.S. Geological Survey editorial standards and stratigraphic nomencalture. (Any use of trade names is for descriptive purposes only and does not imply endorsement by the USGS.)

$I_{\text {Grand Junction, Colorado }}$ 
ABSTRACT......................... 1

INTRODUCTION........................ 4

Previous work..................... 7

Scope and purpose................... 7

Acknowledgements.................... 7

PRODUCTION HISTORY.................... 9

1893-1952, Early years.................. 10

1953-1957, Initial mining............... 13

1958-1961, Development years.............. 23

1962-1966, Productive years.............. 36

1967-1969, Final years.................. 40

Epilog........................... 42

Production summary.................... 43

MINING METHODS....................... 45

URANIUM GEOLOGY...................... 48

The breccia pipe.................... 48

Ore deposits......................... 50

Mineralogy ........................... 58

Origin of the pipe.................... 68

Summary............................ 71

REFERENCES CITED....................... 73 a

APPENDIX............................. 91 


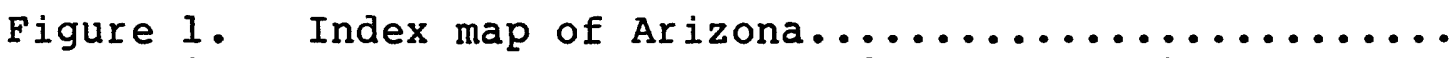

2. Geologic section, Grand Canyon, Arizona.......

3. Oblique aerial photo of the orphan claim......

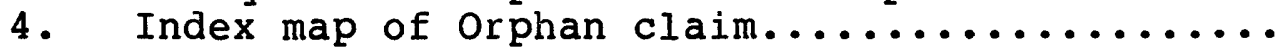

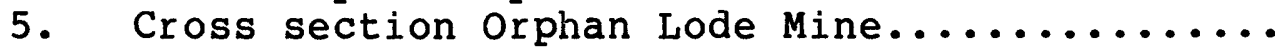

6. Isometric drawing of Orphan Lode Mine,

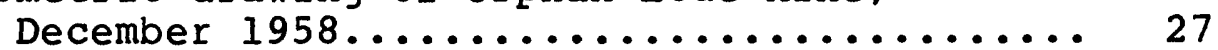

7. Uranium production, Orphan Lode........... 29

8. Plan map of mine workings adit level........ 74

9. Plan map of mine workings 100 level.......... 75

10. Plan map of mine workings 140 level.......... 74

11. Plan map of mine workings 175 level......... 77

12. Plan map of mine workings 190 level.......... 78

13. Plan map of mine workings 225 level.......... 74

14. Plan map of mine workings 245 level......... 80

15. Plan map of mine workings 265 level......... 81

16. Plan map of mine workings 285-290 levels..... 82

17. Plan map of mine workings $310-320$ levels..... 83

18. Plan map of mine workings 335-350-365 levels.. 84

19. Plan map of mine workings 375-400 levels......

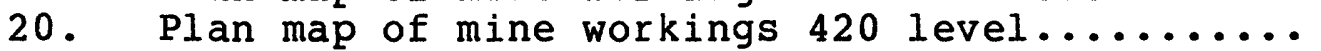

21. Plan map of mine workings 430 level...........

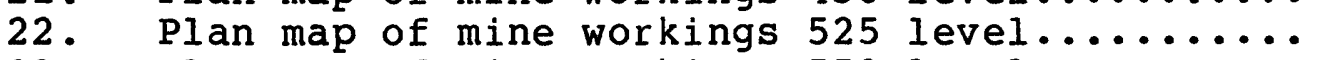

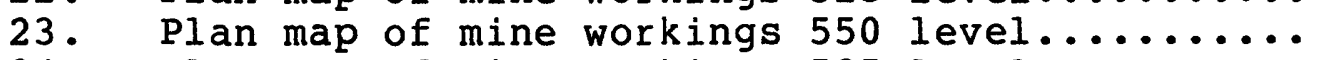

24. Plan map of mine workings 585 level...........

25. Uranium grade distributions from ore shipments and longhole drilling,

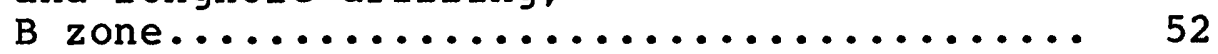

26. Uranium grade distributions from ore shipments and longhole drilling,

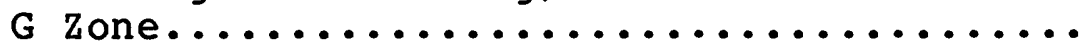

27. Index map showing the location of Figure 28...

28. Vertical cross section, annular ring, looking

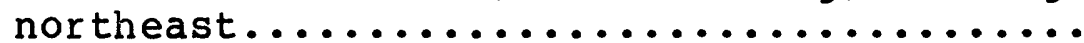

29. Map of 245 level showing production grades in

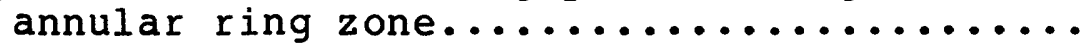

30. Color photo of mineralized fossil plant material in the Esplanade Sandstone,

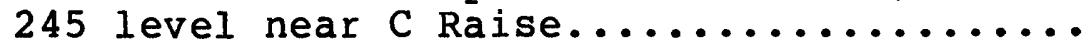

85

86

87

88

89

90

53

55

56

59

60

31. Map of annular ring zone on 310 level showing average uranium production grades, and

referred ore blocks from longhole drilling.

32. Color photo of limonite stained fracture, annular ring, 365 level, note hammer for

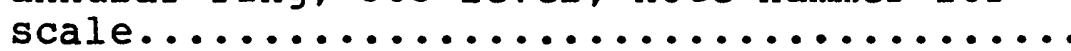

33.

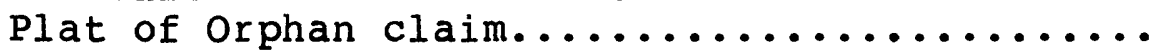

34 .

35 .

36 .

37 .

38 .

Photo of the collapsed ore bin at the Orphan

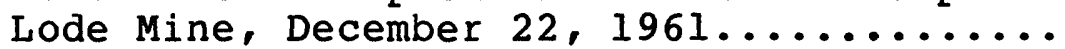

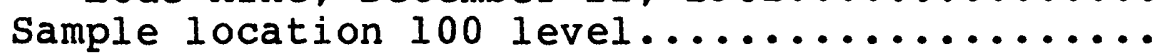

A-7

$A-31$

$\begin{array}{ll}\text { Sample locations } 175 \text { level } \ldots \ldots \ldots \ldots \ldots \ldots \ldots \ldots \ldots & A-32 \\ \text { Sample location } 225 \text { level } \ldots \ldots \ldots \ldots \ldots \ldots \ldots & A-33\end{array}$

Sample location 245 level................. A-34

39 .

A-35 
1. Uranium grades and thicknesses in cores from

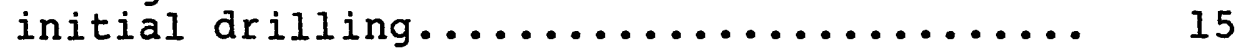

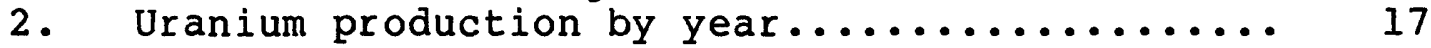

3. Summary of exploration core holes with alphabetic prefixes, Orphan Lode Mine...... 20

4. Vanadium, calcium carbonate, and copper content of early shipments.............. 24

5. Uranium production, Park Service ground....... 39

6. Comparison of production statistics........... 44

7. Analyses of a composite 350 lb. sample from the adit level, Orphan Lode Mine.......... 62

8. Chemical analysis of composite ore samples, representing monthly shipments, Orphan Lode Mine........................ 
THE ORPHAN LODE MINE, GRAND CANYON, ARIZONA, A CASE HISTORY OF A HINERALIZED COLLAPSE-BRECCIA PIPE

William L. Chenoweth

\section{ABSTRACT}

The Orphan is a single, patented lode mining claim within Grand Canyon National Park. The claim was located for copper in 1893, on the escarpment below Maricopa Point on the south rim. Three short adits were driven in mineralized outcrops near the north end line of the claim and a few sacks of copper ore were reportedly brought out of the canyon. It was patented in 1906 before the surrounding area was protected by Federal law. Uranium was noted in the old workings by the USGS in 1951. The claim was leased in 1953 for uranium exploration, and initial drilling in the old adit ( 0 level) determined that the ore-bearing structure was a pipe. On the basis of favorable geology and high grade uranium values (greater than 1.00 percent $\mathrm{U}_{3} \mathrm{O}_{8}$ ) penetrated in a few drill holes, an aerial tram was constructed and production from the Orphan Lode Mine commenced in April 1956. Early ore production was about 1,000 tons-per-month averaging 1.00 percent $\mathrm{U}_{3} \mathrm{O}_{8}$

Continued exploration indicated that ore continued downward to at least the 400 level, and that a large ore body was present off the claim within the National Park. A 1,500 foot deep shaft from the rim of the canyon and a 1,200 foot crosscut to the 400 level of the pipe, completed in 1959, replaced the aerial tram, and production from the orphan Lode greatly increased. 
Public Law 87-457, enacted in May 1962, permitted underground mining adjacent to the claim in the National Park, in exchange for title to the orphan claim in 25 years (1987). Drilling from within the mine located additional ore below the 400 level. When mining ceased in 1969, mine workings and drilling had explored the upper 585 feet of the pipe. During the period 1956-1969, the Orphan Lode Mine produced 495,107 tons of ore averaging 0.42 percent uranium oxide, and containing 4.26 million pounds of uranium oxide. In addition to the uranium, 6.68 million pounds of copper, 107,000 ounces of silver and 3,400 pounds of vanadium oxide were recovered from the ore.

Mining methods at the Orphan Lode varied depending on the location of the ore bodies in and around the pipe, and how the broken ore was transported from the mine to the rim.

The collapse-breccia pipe containing the orphan Lode ore deposit crops out on the south wall of the Grand Canyon near the contact between the Coconino Sandstone and the Hermit Shale of Permian age. It continues downward through the supai Group of Permian-Pennsylvanian age, and bottoms near the middle of the Redwall Limestone of Mississippian age. The pipe is vertical and nearly circular, varying in diameter from about 200 feet to over 500 feet, depending on the lithology of the surrounding sediments. The Orphan Lode breccia pipe has a minimum vertical extent of 1,660 feet.

Ore bodies occurred in the breccia within the pipe, and in the sedimentary rocks surrounding it (annular ring). Sand fill sediments derived from both the Coconino and Esplanade Sandstones, 
were important host rocks within the pipe. The majority of the ore was produced from sandstone units of the Esplanade Sandstone in the annular ring. Sandstones of the Wescogame Formation also were ore-bearing in the annular ring lower part of the mine. Uraninite is the dominant uranium mineral; chalcocite, chalcopyrite, tennantite, and galena are locally present, especially in the annular ring. Pyrite is present throughout the pipe. Within the annular ring, high grade uranium (greater than 1.00 percent $\mathrm{U}_{3} \mathrm{O}_{8}$ ) and copper (greater than 1 percent $\mathrm{Cu}$ ) seemed to be zoned. A calcified zone surrounded the ore in the annular ring. oxidation in the form limonite staining is present throughout the mine, especially in the annular ring. In the adit level, secondary yellow uranium minerals predominate.

A large amount of low grade material, averaging 0.02 percent uranium oxide, is estimated to occur in the lower levels of the pipe. 
Page 4

\section{INTRODUCTION}

The Orphan is a single, patented, lode mining claim within Grand Canyon National Park, about $2 \frac{1}{2}$ miles west of Grand Canyon Village, Coconino County, Arizona (Figure 1). The surface buildings and headframe are only a few hundred yards from the west Rim Drive, between Maricopa and Powell Points. The claim was patented for copper in 1893, before the surrounding area was protected by the National Park Service. It is described as Lot No. 2004, embracing a portion of Section 14, T.31N.,R.2E. of the Gila and Salt River Baseline and Meridian. Public Law 87-457 transfers complete ownership of the claim to the Federal Government in 1987 .

The ore-bearing structure on the claim is a circular, nearly vertical, collapse-breccia pipe which penetrates the Permian and Pennslyvanian strata of the Grand Canyon. The top of the pipe crops out at the Coconino Sandstone-Hermit shale contact; the overlying strata having been removed by erosion. It seemingly bottoms out in the Redwall Limestone (Figure 2). The pipe has a minimum vertical extent of 1,660 feet.

During the mid-1950's the Orphan Lode Mine was developed on the claim and it soon became one of the leading uranium producers on the Colorado Plateau. At depth, the ore extended off the claim into the National Park. A special Act of Congress was necessary to mine this ore. 


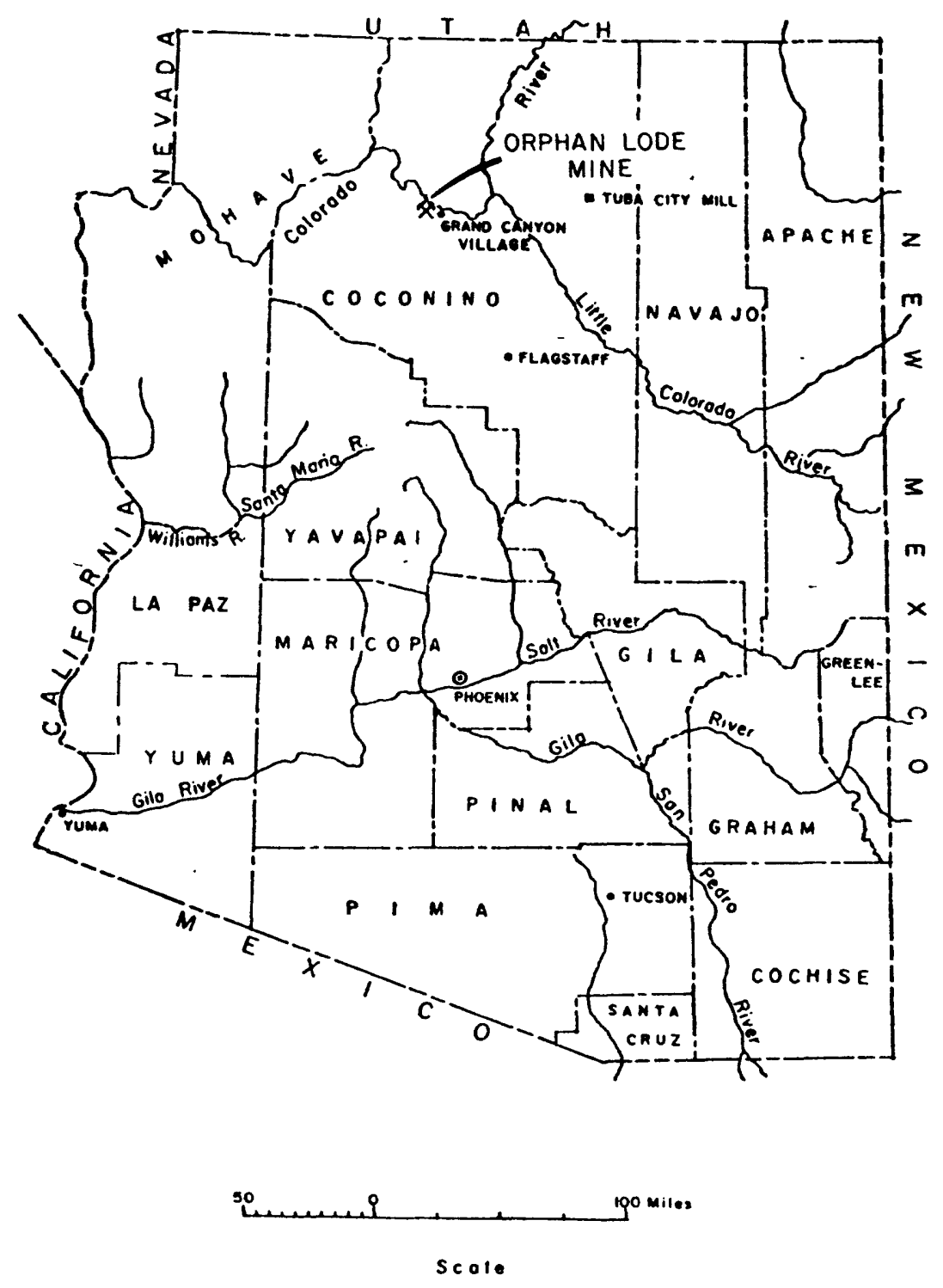

Figure 1. Index map of Arizona showing location of Orphan Lode Mine 


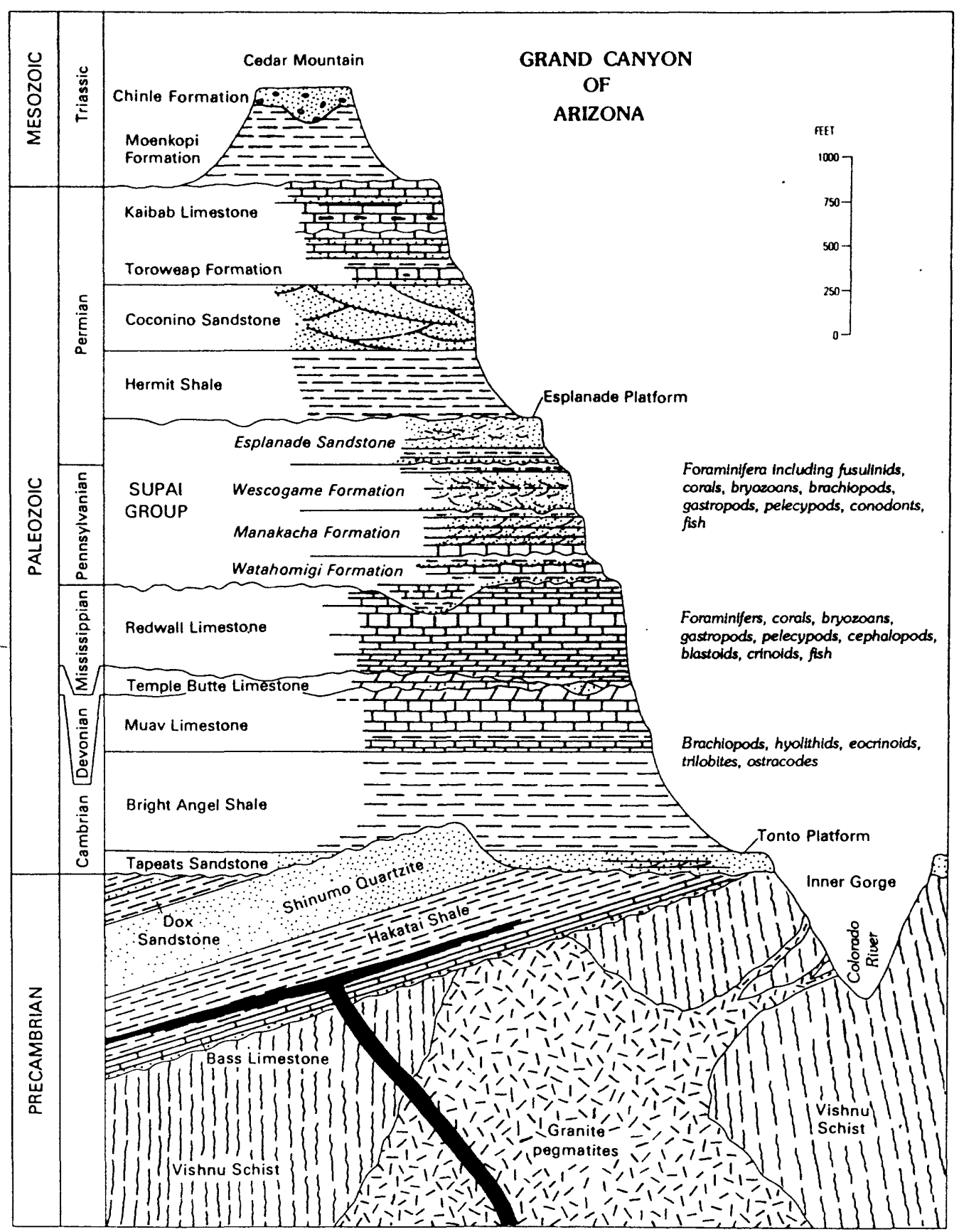

Figure 2. Geologic section Grana Canyon, Arizona (From McKee, 1982) 
Previous Work

Considerable information has been published and/or open filed on the geology of the Orphan Lode. These include reports by Ashwill (1957), Granger and Raup (1962), Gornitz and Kerr (1970), Kofford (1969), Magleby (1961), and Scarborough (1981). Mining activities have been described by the Mining World (1959) and the U.S. Atomic Energy Commission (1959a, 1959b). Historical summaries, glamorized for the lay reader, have been published by Brundy (1977) and Dodge and McKlveen (1970).

\section{Scope And Purpose}

While I was a geologist with the U. S. Atomic Energy Commission (AEC), considerable time in the late 1950's and 1960's was spent examining the Orphan Lode Mine for ore reserve calculations and production capability studies. This report is a summary of my observations during that time.

My field notes and internal AEC trip reports have been drawn upon heavily to complete this summary.

\section{Acknowledgements}

Several organizations have been extremely helpful in locating information on the Orphan Lode. The assistance of Larry D. Fellows, and Robert B. Scarborough, Arizona Bureau of Geology and Mineral Technology, Ken A. Phillips, Arizona Department of Mines and Mineral Resources, W. A. Girdley, Ersel Reid, and Larry M. Fukui, Bendix Field Engineering Corporation, and Merle E. Crew, U.S. Department of Energy is gratefully acknowledged.

Discussions with Erik W. Bruner, Cotter Corporation, and long time mine geologist at the Orphan Lode, were exceedingly helpful in confirming my poorly recorded observations. A critical review 
of the manuscript by Karen J. Wenrich and Harry C. Granger greatly improved it.

Financial support for this research project was supplied by Karen J. Wenrich of the U.S. Geological Survey, with funds from the Bureau of Indian Affairs for her project on breccia pipes of northern Arizona. 
Page 9

\section{PRODUCTION HISTORY}

The Orphan Lode Mine has had a long and interesting history. A summary of the following narrative is given in the Appendix (page $A-1)$.

\section{3 - 1952 Early Activities}

Daniel L. Hogan began prospecting in the Grand Canyon about 1890. On February 8, 1893, he and his partner, Henry Ward, located the Orphan claim between Powell and Maricopa Points on the south $\mathrm{rim}$ of the Grand Canyon (Figure 3). The single claim covered an outcrop of copper minerals that occurred some 1100 feet below the rim of the canyon. Thinking that the deposit occurred as a vein, the claim was located with the outcrops near the north end line; most of the claimed land extended to the southwest, including a few acres on the rim.

Hogan and Ward built a crude trail consisting of ropes, ladders, and rock steps down the rim to the copper showings and did a small amount of mining. Three short adits were driven into the mineralized outcrops. A few sacks of copper ore were reportedly brought out of the canyon.

After serving as a Rough Rider in the Spanish-American War, Hogan returned to prospecting. Ward sold his interest in the Orphan to Charles J. Babbitt, a northern Arizona merchant, who 


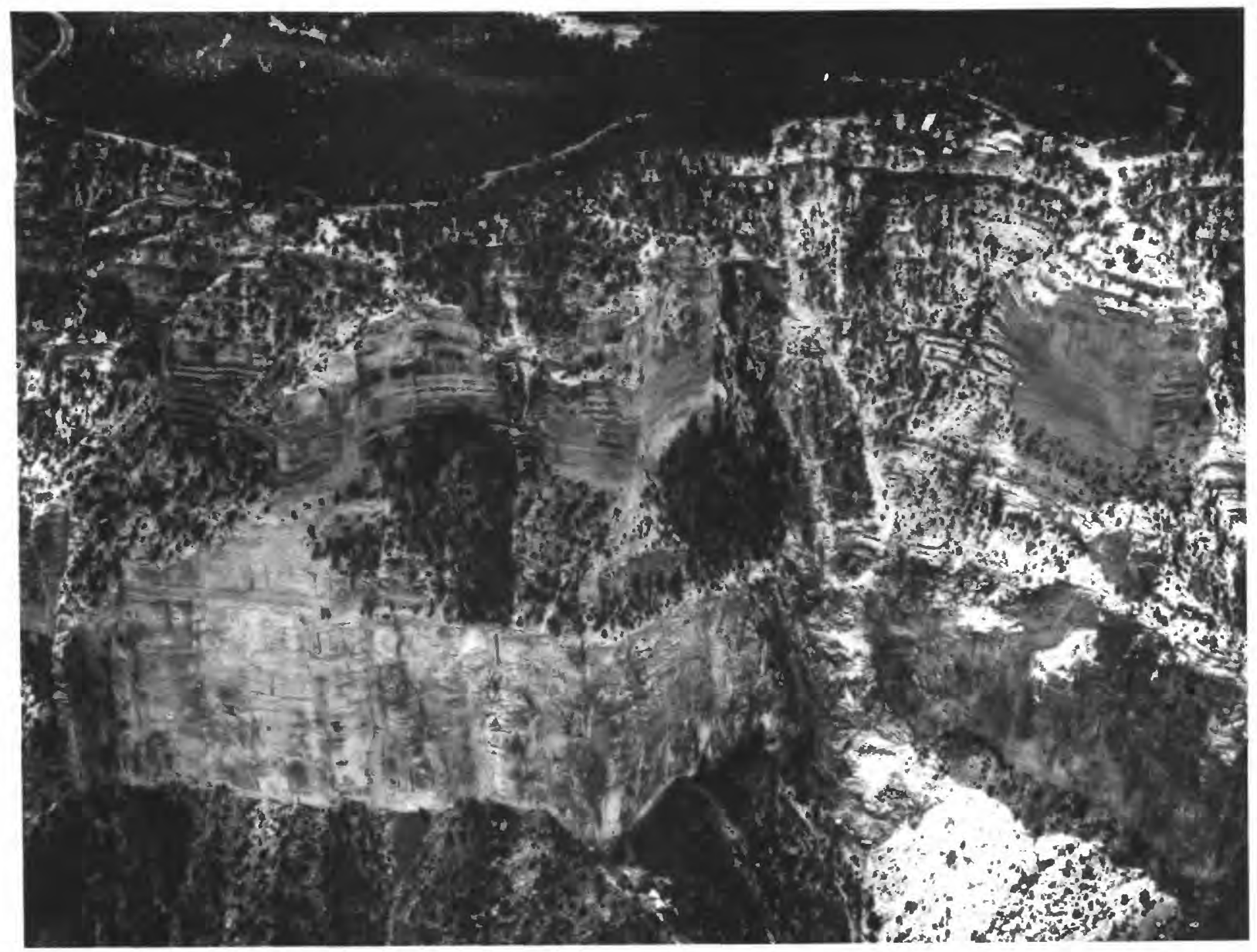

Figure 3, Oblique aerial photo of the south rim of the Grand Canyon showing Maricopa point (center) and Powell Point (right). The Orphan claim is located between the two points. Vertical cliff in lower part of photo is the Coconino Sandstone. Top of the Orphan Lode pipe is at the Coconino and underlying Hermit shale contact. zig-zag scar on canyon wall is a trail that was built during the installation of the aerial tram. Photo by George Hood (AEC). 
reportedly grubstaked Hogan. The Orphan claim was surveyed (Mineral Survey No. 2004) on January 18-20, 1905 and was found to contain 20.26 acres (see Figure 33 , p. A-5). It was patented (Patent No. 43506) on March 23, 1906 with C. J. Babbitt listed as a coowner with Hogan (Brown, 1955). The patent was reportedly signed by President Theodore Roosevelt, Hogan's old commandant (Dodge and McKlveen, 1970). Although the official name of the claim was the Orphan, Hogan referred to it as the orphan Lode, and the Little Orphan Girl (Dodge and McKlveen, 1970).

On November 28, 1906, President Theodore Roosevelt signed a bill proclaiming the Grand Canyon Game Reserve. To further protect the area, President Roosevelt established the Grand Canyon National Monument on January 11, 1908. The primary effect of this legislation was to forbid prospecting and mining on all lands in the Grand Canyon which were not already covered by valid claims (Billingsley, 1974).

On February 16, 1919, President Woodrow Wilson proclaimed the Grand Canyon as a National Park. Congress revised the boundaries of Grand Canyon National Park in 1927. A new Grand Canyon National Monument was established by President Herbert $C$. Hoover on December 22,1932 (Billingsley, 1974).

Hogan acquired full interest in the claim on April 18, 1912 when C. J. Babbitt quit-claimed Hogan his interest (Brown, 1955). Being unsuccessful in making a copper mine of the claim, Hogan built a tourist lodge on the rim portion in 1935. This structure was originally known as the Grand Canyon Trading Post, but would later be called the Kachina Lodge and Grand Canyon Inn. 
Because it was located on privately-owned land within the National Park, the lodge was considered a nuisance and eyesore by the Park Service. All water for the facility had to be hauled in from outside the park. Due to the lack of tourists during world War II, and continuing problems with the Park Service, Hogan sold his Orphan claim to Mrs. Bertha Madeleine Jacobs on August 1 , 1946 for $\$ 55,000$ (Brown, 1955). On June 1, 1951, Jacobs sold the surface rights to David and James Barrington for $\$ 125,000$ (Brown, 1955).

Early in 1951, amateur prospectors discovered anomalous radioactivity on the rim of Grand Canyon, just east of the Grand Canyon Inn (Kofford, 1969). The area of the discovery was near the head of Hogan's old trail, and was where he had stockpiled his copper ore. The existence of the radioactivity became known to the employees of the Inn and to Mrs. Jacobs.

During the early 1950s, Harry C. Granger of the U. S Geological Survey (USGS) examined all of the known and reported occurrences of uranium in Arizona and looked for other based on geologic evidence. At the urging of Charles Anderson, of the USGS, Granger contacted Mrs. Jacobs of Prescott, Arizona, regarding a copper prospect in the Grand Canyon. Copper deposits in sedimentary rocks were known to contain uranium at many localities on the Colorado Plateau. Samples in Mrs. Jacobs' possession were checked by Granger using his geiger counter but were found to be so low in radioactivity that a special trip to the Grand Canyon could not be justified (H.C. Granger, oral communication, 1985). Interested in seeing a property in the Grand Canyon, Granger made 
a weekend trip to the canyon and examined the old Hogan workings on April 22, 1951. His geiger counter readings and chemical analysis of samples confirmed that outcrops at the portal of the lower adit contained high-grade uranium (Grand Junction Office, AEC and USGS, 1970, p. 110). Granger's initial observation was that the ore occurred in a slump block of Coconino Sandstone in the Hermit Shale (Granger, 1951).

After learning that the claim had high-grade uranium on it, Mrs. Jacobs leased the mineral rights to a few small mining companies. Lack of capital and inaccessability hindered development of the deposit for a few years.

\section{3 - 1957 Initial Mining}

Through the efforts of Arthur R. Still, a consulting geologist in Prescott, Arizona, Golden Crown Mining Company, a subsidiary of Western Gold and Uranium, Inc., leased the mineral rights to the Orphan on September 29, 1953. The lease carried a 10 percent royalty with an option to purchase the mineral rights for $\$ 20,000$ (Brown, 1955). A dispute with the surface owner was resolved when Golden Crown completed the lease and option. In 1956, Golden Crown acquired complete ownership of the claim including the Grand Canyon Inn.

In order to test the amenability of the ore at the orphan claim to conventional uranium milling circuits, Golden Crown submitted a 350 pound sample to the AEC's Grand Junction Office in the summer of 1954. This was a composite sample collected in the old Hogan adit (see Figure 8). Analysis by the National Lead Company's Raw Materials Development Laboratory at Winchester, 
Massachusetts indicated the sample contained 0.217 percent $\mathrm{U}_{3} \mathrm{O}_{8}, 1.45$ percent $\mathrm{V}_{2} \mathrm{O}_{5}, 0.81$ percent $\mathrm{Cu}$, and 3.6 ounces of silver per ton (Lynch and Viklund, 1956). The sample was found to be amenable to both acid or alkaline leaching.

Geologic mapping of the old Hogan adit commenced, and exploration diamond drilling began in october 1955. On December 14, 1955 Golden Crown issued a letter to its stockholders announcing that a major uranium deposit had been located on the orphan claim. The deposit was purported to contain not less than 100,000 tons of ore or might contain as much as 300,000 tons averaging 0.45 percent $\mathrm{U}_{3} \mathrm{O}_{8}$. The ore-bearing structure was stated to be a pipe (see Appendix, p. A-6).

On February 16, 1956 the company released the core analyses from the first 14 holes (Table 1). On the basis of the drilling results and favorable geology, construction of a three tower aerial tram from the rim to the north end of the claim was begun in March 1956 (Figure 4). The initial shipment of ore from the Orphan Lode to the Atomic Energy Commission's (AEC) buying station near Tuba City, Arizona was made on April 25, 1956. This shipment consisted of 20.89 tons of ore that averaged 0.53 percent $\mathrm{U}_{3} \mathrm{O}_{8}$ (Table 2). This shipment, and all following shipments were identified to the AEC as the Orphan Lode Mine, hence the name used in this report. 


\section{TABLE 1}

Uranium grades and thicknesses in cores from initial drilling, Orphan Lode, Coconino County, Arizona.

\begin{tabular}{cccc} 
HOLE NO. & GRADE $\left(8 \mathrm{U}_{3} \mathrm{O}_{8}\right.$ & Depth or Thickness (Feet) \\
\cline { 1 - 1 } $\begin{array}{c}0.378 \\
2\end{array}$ & 0.464 & & 11.0 \\
3 & 0.284 & & 11.5 \\
4 & 0.233 & & 17.5 \\
$5 *$ & 1.112 & & 30.0 \\
6 & 0.224 & & 21.5 \\
$7 * *$ & 1.002 & 31.5 \\
8 & 0.152 & 53.0 \\
$9 \& 10$ & Creviced - not completed & 3.0 \\
11 & 0.087 & & \\
12 & 0.042 & & 217.0 \\
13 & 0.043 & & 130.0 \\
14 & 0.051 & & 40.0 \\
& &
\end{tabular}

* In hole 5, 3.5 feet averaged $3.138 \mathrm{U}_{3} \mathrm{O}_{8}$

** In hole $7,21.7$ feet averaged $1.718 \mathrm{U}_{3} \mathrm{O}_{8}$

Source: Golden Crown Mining Co. press release dated February 16, 1956. 


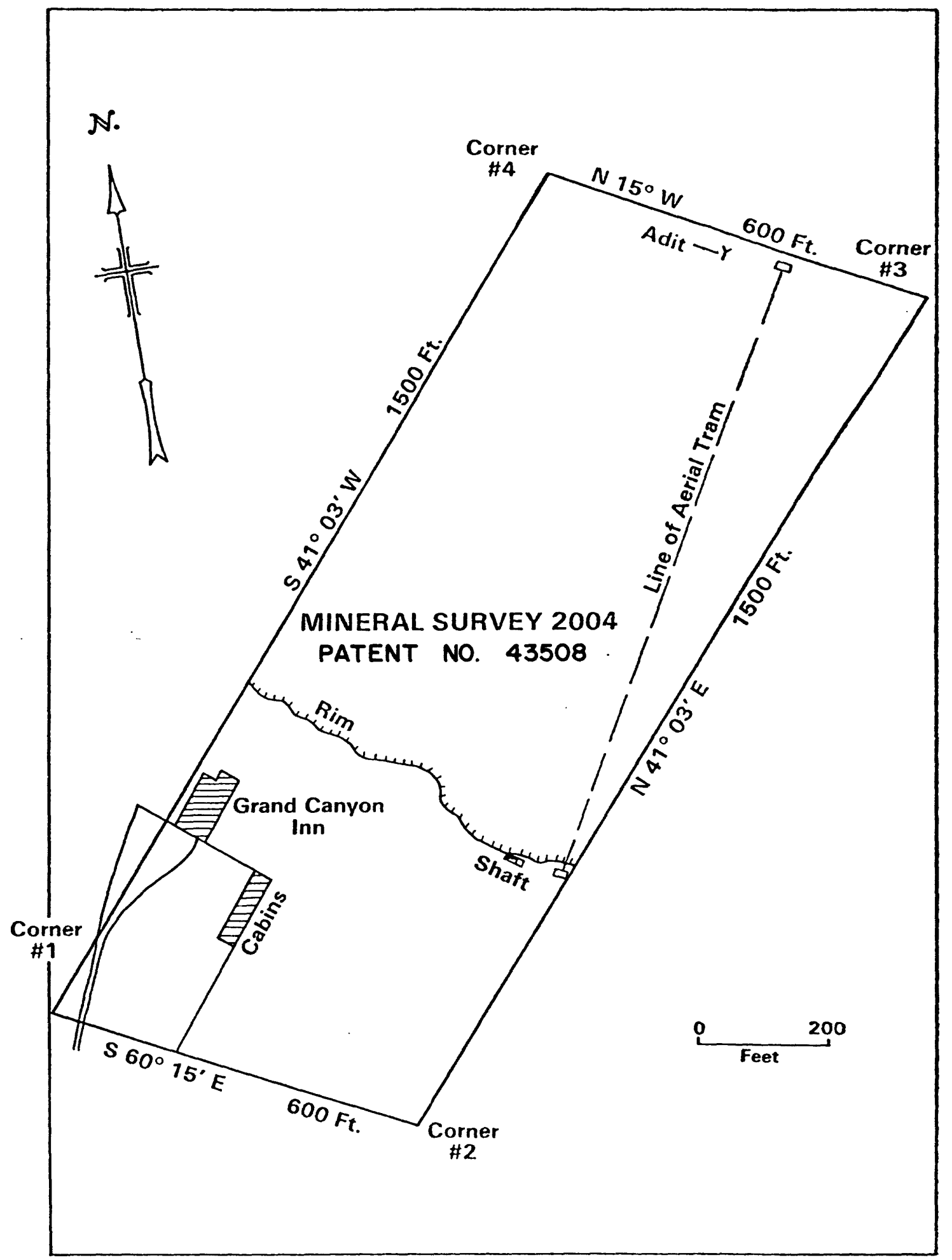

Figure L. Index map of Orphan claim 
TABLE 2

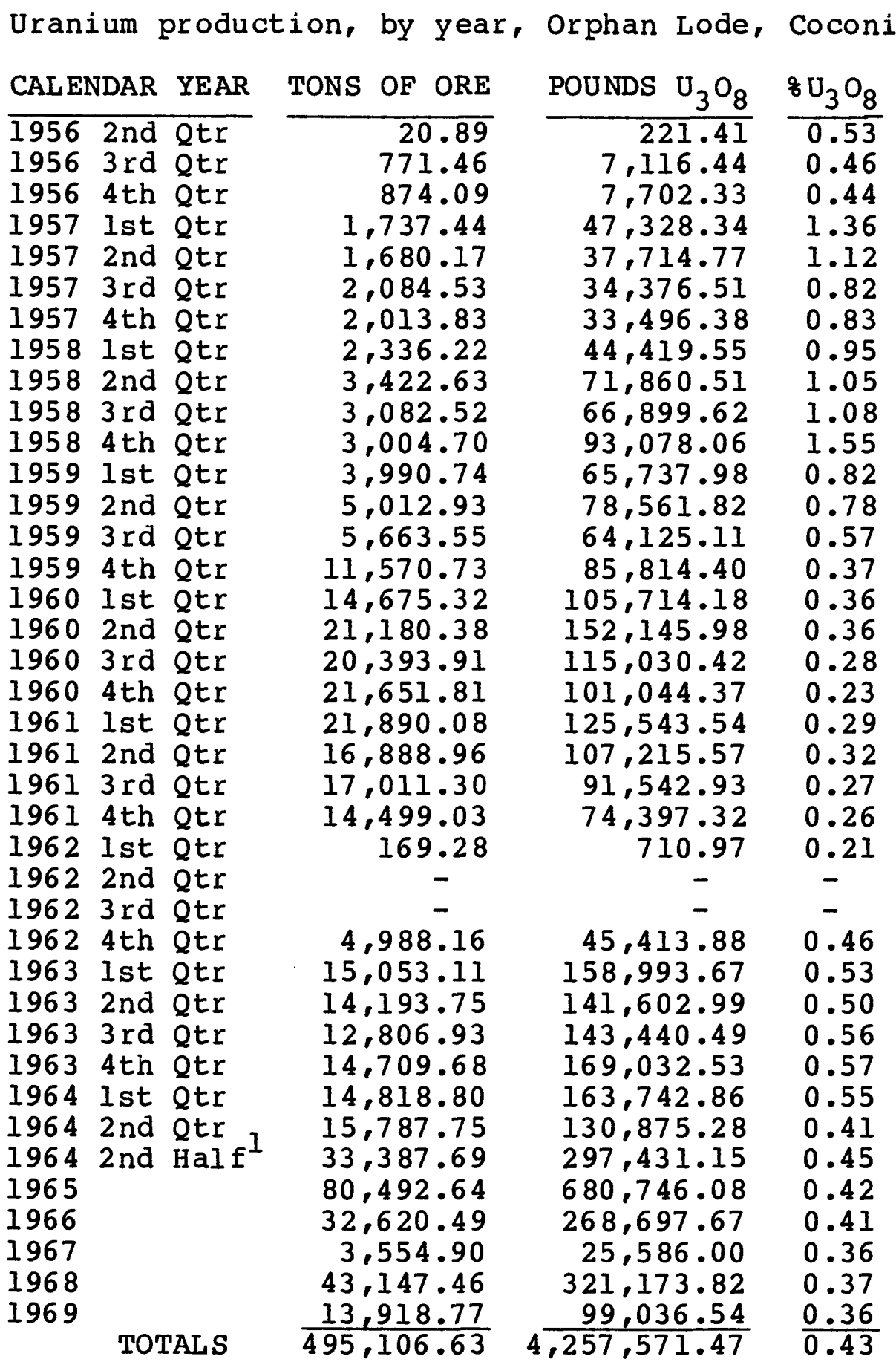

$I$ - Production by quarters not available after July 1, 1964

Source: U. S. Atomic Energy Commission files, Grand Junction office 
The Rare Metals Corporation of America, which had proven reserves in the Cameron, Arizona area, began construction of a uranium processing mill 6 miles northeast of Tuba City, Arizona in late 1955. While the mill was under construction, the AEC opened an ore buying station at the millsite. The mill began operating in June 1956 and the buying station was closed in July 1956. Ores from the buying station were purchased and processed by Rare Metals (Albrethsen and McGinley, 1982). The mill had a capacity of 300 tons-per-day, and used a sulfuric acid leaching process to extract the uranium. Ores containing more than 6 percent lime $\left(\mathrm{CaCO}_{3}\right)$ were penalized, due to excessive acid consumption. Uranium concentrates produced by Rare Metals were sold to the AEC under Contract No. AT(05-1)293. Ores from independent producers, including the Orphan Lode, were purchased by Rare Metals under the terms of the AEC's Circular 5, Revised.

Ore from the Orphan Lode was trucked to Tuba City--a distance of 92 miles. The Park Service charged Golden Crown a fee of \$0.02 per-ton-mile for use of roads within the National Park.

On May 24, 1956, the AEC announced the establishment of a new domestic uranium procurement program for the period April 1 , 1962, through December 31, 1966. The new program guaranteed a Government market for 500 tons of $\mathrm{U}_{3} \mathrm{O}_{8}$ in concentrate (yellowcake) per year from any one mining property or operation at a flat price of $\$ 8$ per pound. Thus, in 1956, the stage was set for a continuing AEC concentrate procurement program after March 31 , 1962, with an established price for concentrates rather than for ores. The prices, premiums, and allowance paid under Circular 5, 
Revised, would no longer be in effect. After March 31, 1962, the AEC required that the mill operator pay "reasonable" prices to independent producers.

The original aerial tram proved ineffective and was removed. A Riblet tram was completed in May 1956 at a cost of $\$ 61,800$ (Mining World, 1959). The tram was 1,800 feet long, using an endless steel rope supported on eight towers, and descended 1,100 feet at slopes of $37^{\circ}$ and $57^{\circ}$. Two tram buckets, each with a capacity of eight cubic-feet, operated in tandem and required four minutes for the trip. All mine personnel and equipment were taken to and from the mine via the tram buckets. Sustained production using the new aerial tram commenced in August 1956. When operating smoothly it could move 45 tons of ore per day to the rim.

A new adit was driven parallel to the Hogan adit, and a two compartment, vertical exploration winze was started about 90 feet from the portal in September 1956 (see Figure 8). By March 1957, the winze had reached a depth of 175 feet (the 175 level). At the Orphan, mine levels refer to the depth below the adit level (Figure 5).

Exploration drilling during 1956 and 1957 from the 100 and 175 levels continued to locate ore on the north side of the pipe as well as within the pipe. This drilling was known as the $A, B$, D, $E$ and $F$ series of diamond drill holes. Total footage was about 4,000 feet in 25 holes (Table 3 ). The high grade ore on the north perimeter of the pipe was named the $A$ zone and the lower grade ore in the pipe was called the $B$ zone by company 


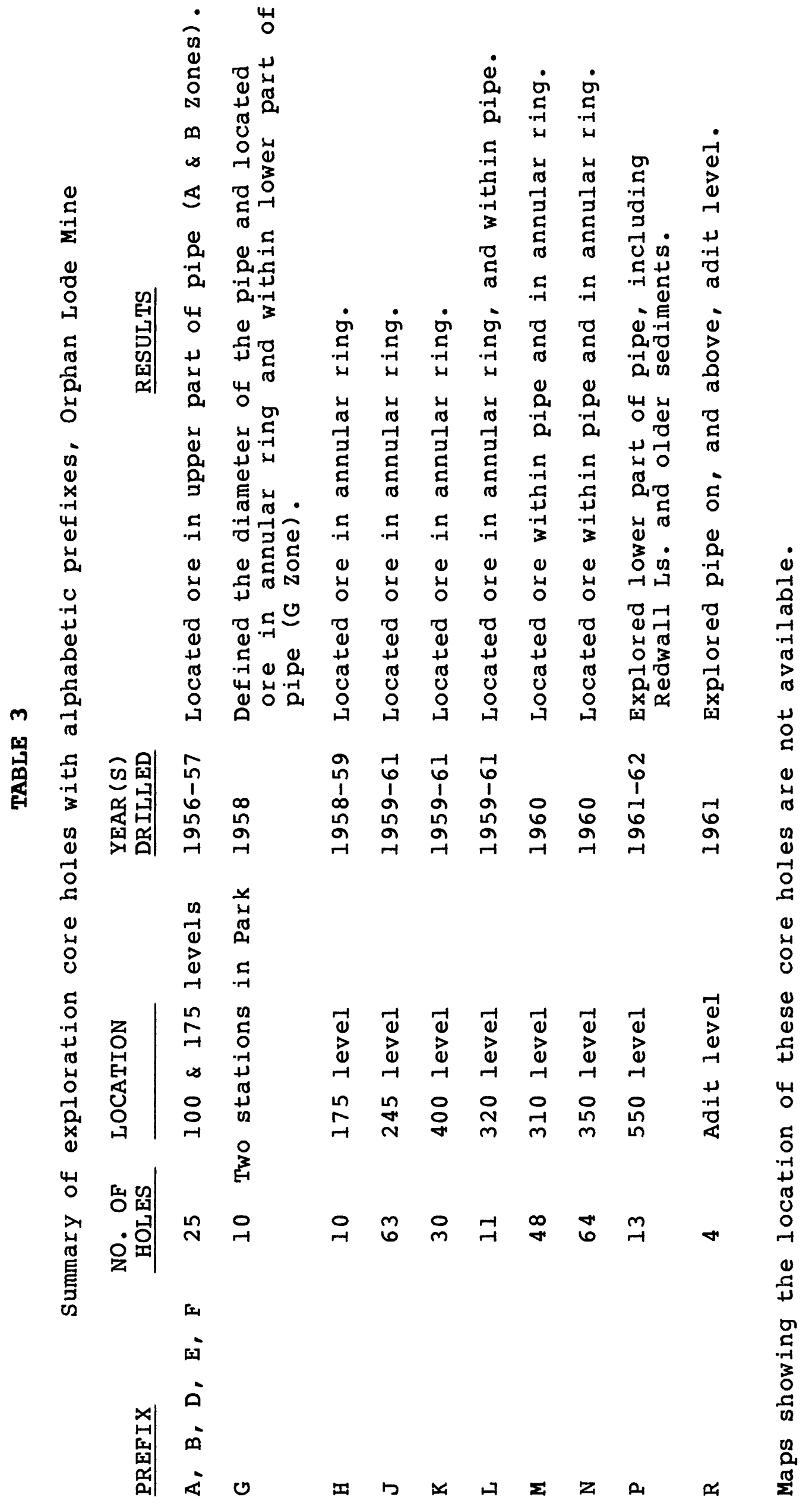




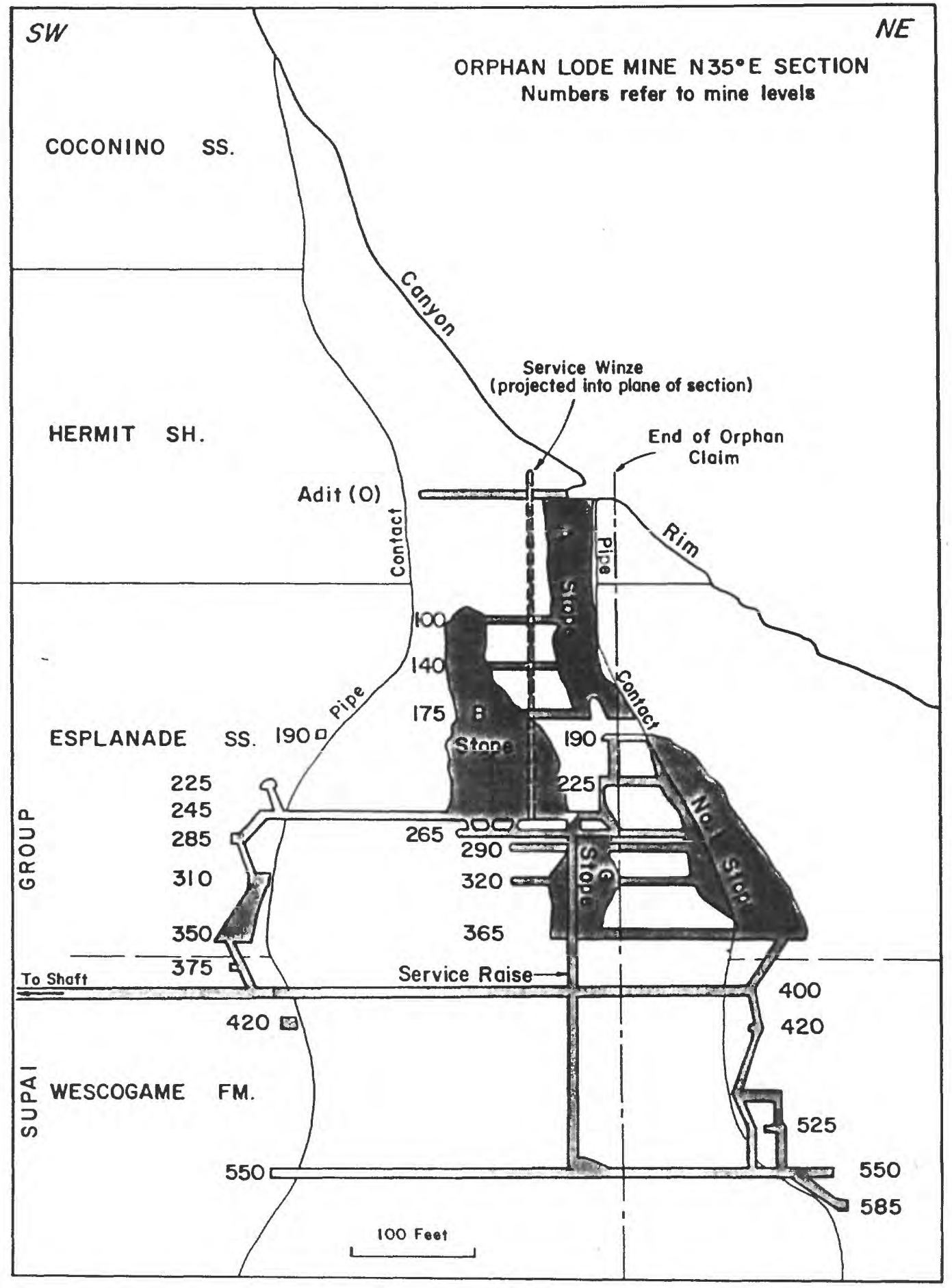

Figure 5. Cross Section, Orphan Lode Mine (Modified from Gornitz and Kerr, 1970) 
engineers and geologists (Figure 5). The initial mining at the Orphan concentrated on the A zone which consisted of Coconino sand fill which was cemented by uraninite. Production in 1956 totaled 1,666 tons of ore averaging $0.458 \quad \mathrm{U}_{3} \mathrm{O}_{8}$ (Table 2).

In July 1957, Western Gold and Uranium, Inc. acquired full control of Golden Crown Mining Company and became the operator of the Orphan Lode Mine. Also during 1957, the service winze at the Orphan was deepened from the 175 level to the 245 level. Drilling from within the mine intercepted ore grade material as deep as the 400 level within the pipe. Drilling also indicated that the ore body on the northside of the pipe in the upper levels of the mine plunged to the north and went off the claim into the National Park.

Since there was no room on the claim to dump waste near the adit, and since the Park Service prohibited any activity off the claim, all waste from development had to be disposed of underground. This was done by backfilling stopes and other mined out areas. Production during 1957 was 152,916 pounds $\mathrm{U}_{3} \mathrm{O}_{8}$ in 7,515 tons of ore which averaged 1.02 percent $\mathrm{U}_{3} \mathrm{O}_{8}$ (Table 2). The lime content of the ore on the 175 levels was becoming a problem and reached as high as 14.00 percent $\mathrm{CaCO}_{3}$ for a three month period in the summer of 1957 (Table 4).

Shipments for January 1957 totalled 726 tons averaging 2.29 percent $\mathrm{U}_{3} \mathrm{O}_{8}$, the highest monthly grade ever achieved by the Orphan Lode. C.M. Brundy (1977), a former employee of Western Gold and Uranium, noted that the highest single shipment from the mine, averaged 4.09 percent $\mathrm{U}_{3} \mathrm{O}_{8}$. 


\section{8 - 1961 Development Years}

Nineteen-fifty-eight was a very important year in the history of the Orphan Lode. The developments in this, and the following years, would have a great impact on the future of the mine.

In April 1958, Western Gold and Uranium obtained Special Use Permit No. GRCA-5-58 to establish two surface drill stations north of the claim in the National Park. From these two stations the G series of core holes were drilled in a southerly direction into the pipe. Ten holes with a total footage of 6,175 feet were drilled between July and October, by Boyles Brothers, a drilling contractor (Table 2).

This drilling was highly significant as it indicated: 1) the pipe increased in diameter at the Hermit - Supai contact, near the 175 level, 2) a large ore body was present on the north side of the pipe, off of the Orphan claim, 3) ore was present on the south side of the pipe, and 4) ore in the pipe extended below the 245 level.

At the same time as the $G$ series were being drilled from the surface, a long and short hole percussion drilling program was in progress underground to outline the low grade hole of ore surrounding the high grade ore bodies on the 140, 175, and 245 levels.

In May 1958, a contractor, Centennial Development Company, began sinking a $2 \frac{3}{2}$ compartment shaft from the rim of the canyon (Figure 4). A 1,200 foot crosscut from the shaft was planned to intersect the pipe at the 400 level. The shaft was completed to a depth of 1,590 feet in January 1959, with a station cut at 1,502 feet. The reported cost of the new shaft was about $\$ 800,000$ 


\section{TABLE 4}

Vanadium, calcium carbonate and copper content of early uranium shipments, Orphan Lode, Coconino County, Arizona.

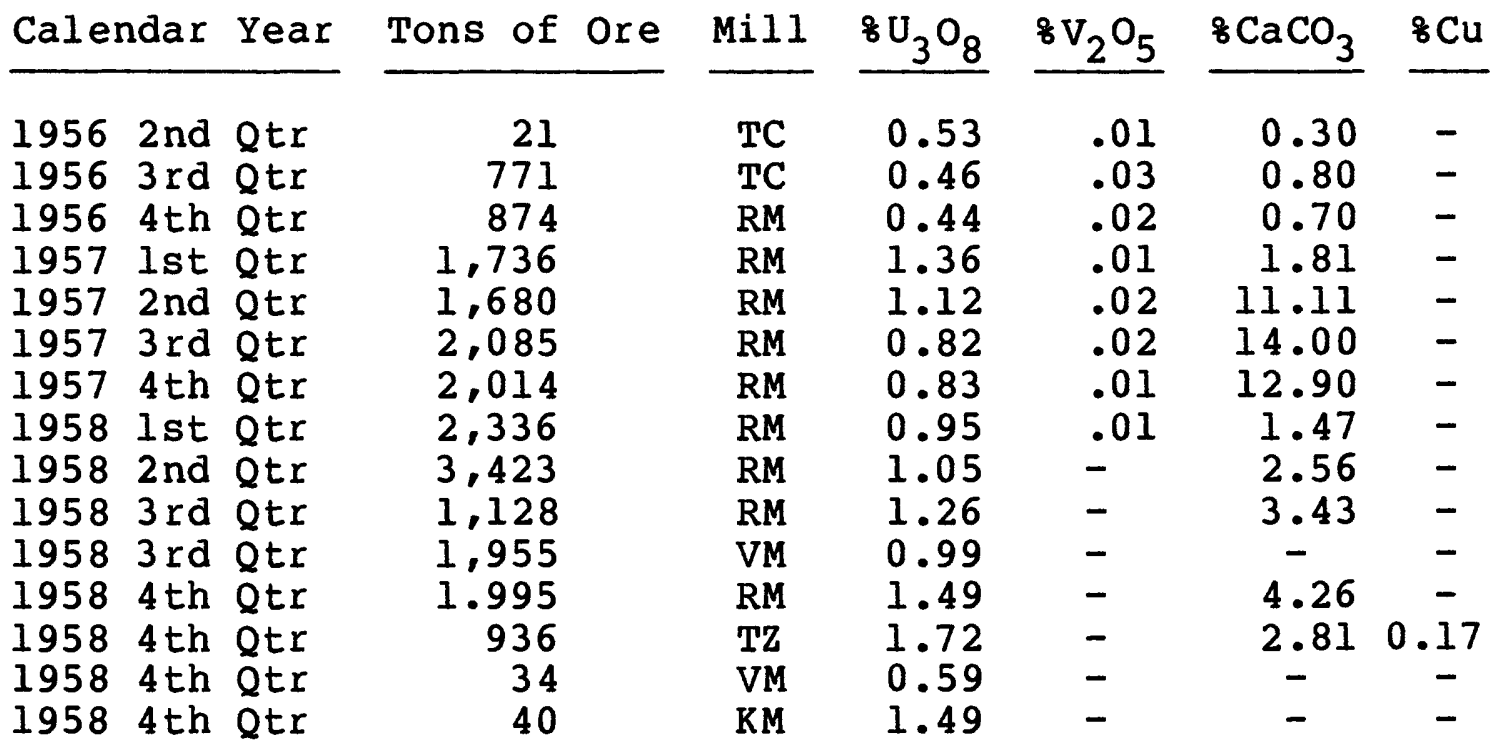

TC - AEC, RM - Rare Metals, VM - Vitro Corp., TZ - Texas Zinc Minerals, KM - Kermac Nuclear Fuels

Source: U. S. Atomic Energy Commission files, Grand Junction Office. 
which was paid for in cash from profits made on the mined ore (Mining World, 1959).

The crosscut from the shaft station to the 400 level of the pipe was started on March 20, 1959. It was completed to the end line of the claim in August 1959.

All waste from the shaft and crosscut had to be hauled to a dump site the company had leased from the Forest Service near Rowes Well. A fee of $\$ 0.02$ per ton mile was charged to use Park roads, the same as the ore trucks. However, considerable quantities of the waste was purchased by the Park Service for road ballast.

Production goals for 1958 were set at 1,000 tons per month of ore averaging 1.00 percent $\mathrm{U}_{3} \mathrm{O}_{8} \quad\left(20,000\right.$ pounds $\left.\mathrm{U}_{3} \mathrm{O}_{8}\right)$, in order to pay for the new shaft. The high grade ore was being mined from the $A$ zone and the 1,000 tons-per-month was the capacity of the aerial tram. In June 1958, Rare Metals Iimited the Orphan Lode to 16,950 pounds of $U_{3} \mathrm{O}_{8}$ per month that would be accepted at the Tuba City mill. With this limitation, Western Gold sought markets at other mills. Shipments were made to the Vitro Corporation at Salt Lake City, Utah, Texas-zinc Minerals at Mexican Hat, Utah, and Kermac Nuclear Fuels at Ambrosia Lake, New Mexico (Table 4). The Texas-Zinc mill at Mexican Hat, had a sulfide flotation circuit which recovered copper (Albrethsen and McGinley, 1982). The production limitation at Tuba City was increased to 18,000 pounds $\mathrm{U}_{3} \mathrm{O}_{8}$ per month in November 1958 .

In December, 1958, Western Gold obtained another special use permit from the Park Service to build 2.5 miles of new road in the Park. The new road would provide access to railroad siding 
on the Atchison Topeka and Santa Fe Railway right-of-way within the Park. Here, a loading ramp was built in order to make shipments to mills in New Mexico.

Drilling of the $H$ series of core holes on the 175 level began in December 1958 (Table 3). By the end of the year, drilling had indicated: 1) ore within the pipe was restricted to above the 375 level, with the higher grade occurring above the 245 level (B zone), 2) at the 310-350 level, ore was believed to be continuous around the perimeter of the pipe, which at these levels had a diameter of approximately 450 feet. Hence, a concept of annular ring ore bodies was developed. Further drilling would discover only ore in the lower levels of the pipe in the annular $r i n g$. A sketch of the mine working as of the end of 1958 is shown in Figure 6 . 


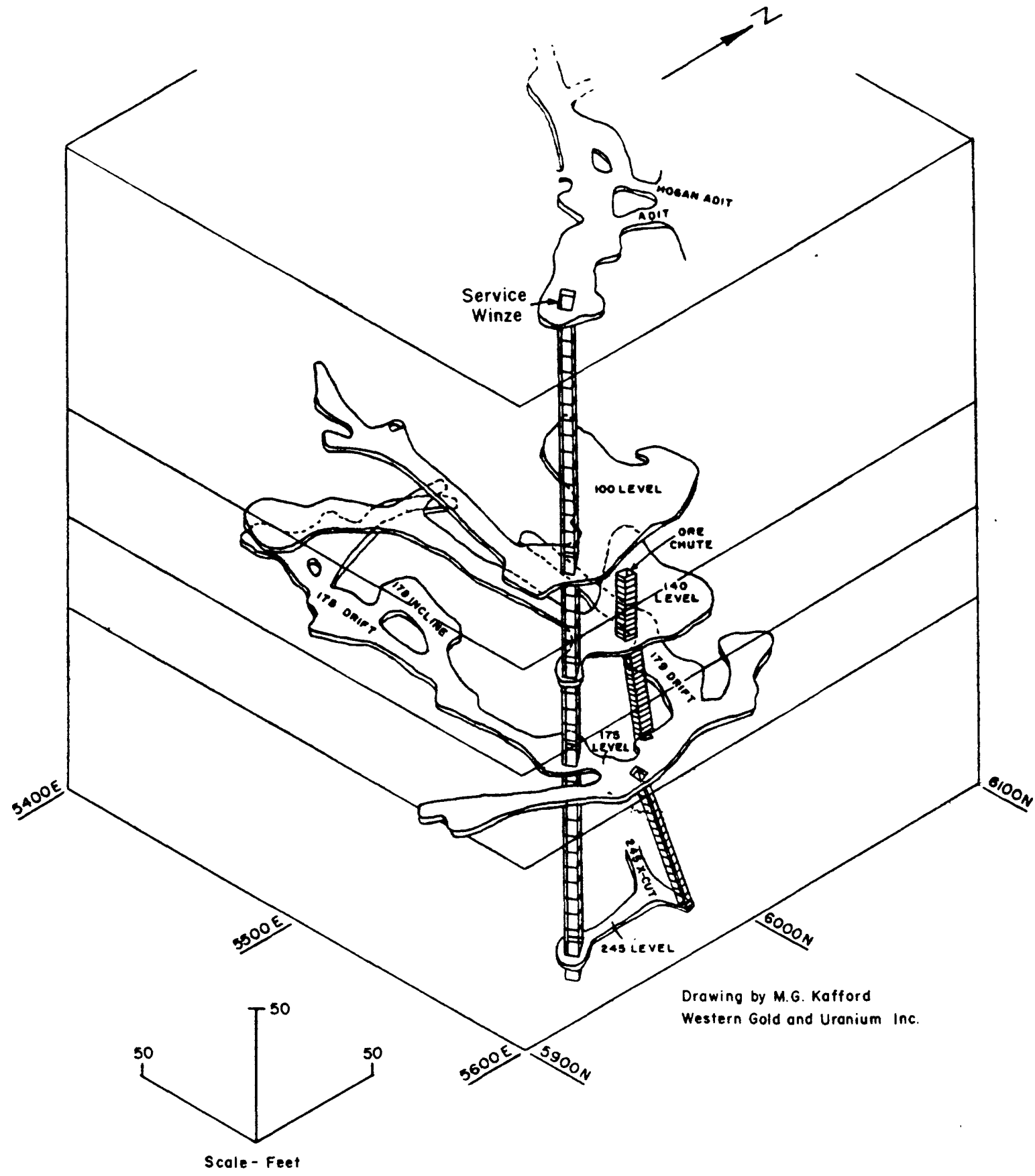

Figure 6. Isometric drawing of Orphan Lode Mine, December 1958 
Production in 1958 totalled 11,846 tons averaging 1.17 percent $\mathrm{U}_{3} \mathrm{O}_{8}$ and containing 276,258 pounds $\mathrm{U}_{3} \mathrm{O}_{8}$, a sharp increase over 1957 (Table 2, Figure 7). M.E. Kofford (personal communication, 1959) reported that Iime penalties through 1958 had totalled $\$ 20,307.51$

The dramatic increase in uranium ore reserves occurring throughout the United States during 1957 and 1958 was of concern to the AEC. On November 24, 1958, in order to prevent further expansion of production under its essentially unlimited purchase commitment, the AEC redefined its $1962-1966$ procurement program by withdrawing portions of the program announced in May 1956. The Government stated it would buy, in the 1962-1966 period, only "appropriate quantities of concentrate derived from ore reserves developed prior to November 24, 1958, in reliance upon the May 24, 1956, announcement." Other aspects of the program announced in 1956 were retained: The AEC would buy only concentrates; the $\mathrm{U}_{3} \mathrm{O}_{8}$ price would remain at $\$ 8$ per pound; and ores would not be purchased nor ore prices guaranteed. Independent producers had to negotiate ore purchase contracts with milling companies in order to sell their ores.

In the negotiations that followed this announcement, the AEC would recognize only the ore that had been developed on the claim to be eligible for a market quota (allocation). The ore that Western Gold and Uranium had developed in the Park was considered, by the AEC, to be property of the U.S. Government. 


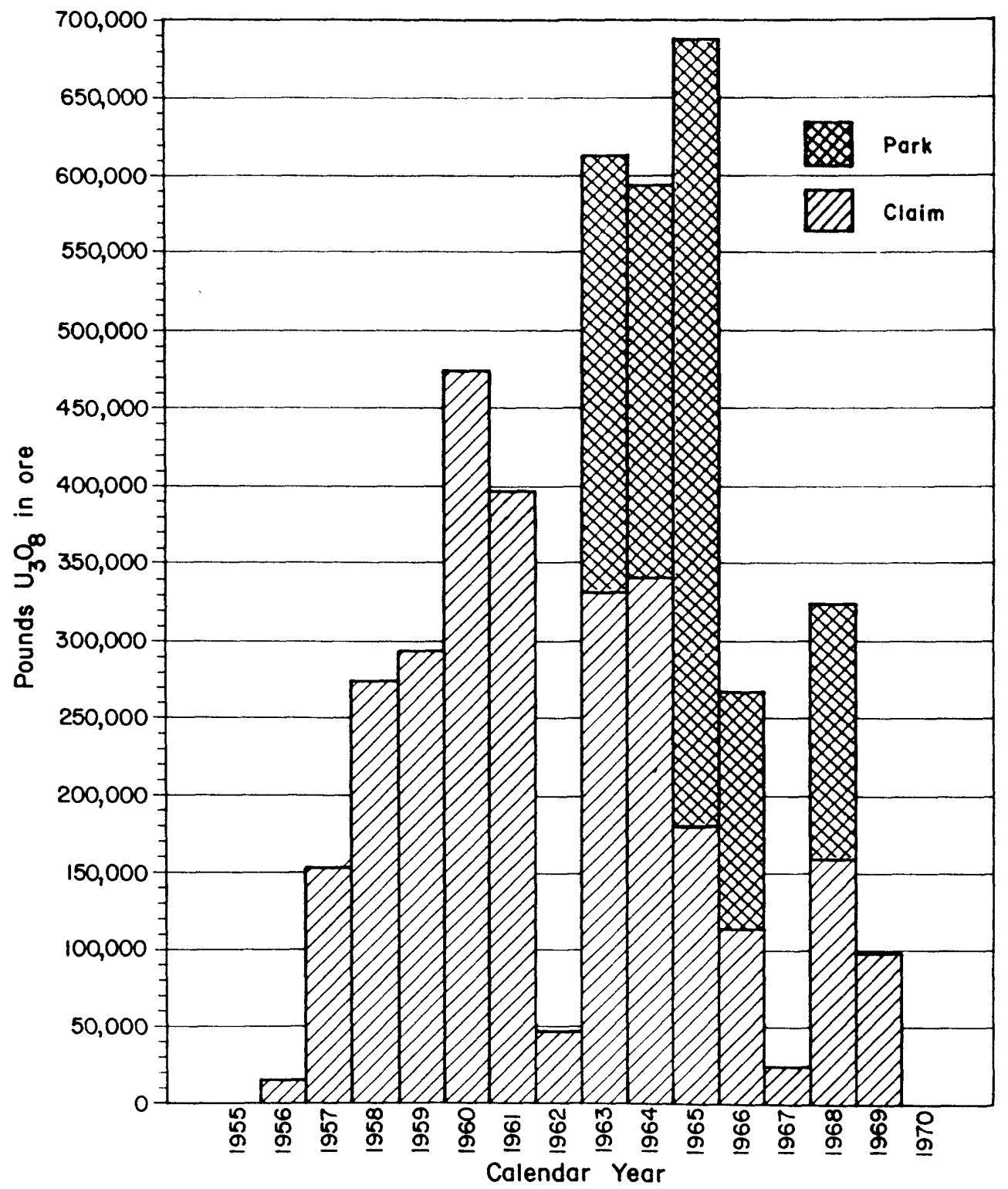

Figure 7. Eranium production Orphan Lode Mine, Coconino County, Arizona 
Western Gold and Uranium calculated their "indicated, inferred and, possible reserves" for the Orphan Lode as 1,543,000 tons averaging 0.42 percent $\mathrm{U}_{3} \mathrm{O}_{8}$ (personal communication, Kofford M. G., 1959). Official AEC reserves for November 24, 1958, were 296,000 tons of indicated and referred reserves averaging 0.38 percent $\mathrm{U}_{3} \mathrm{O}_{8}$ on the claim, and 228,000 tons averaging 0.51 percent $\mathrm{U}_{3} \mathrm{O}_{8}$ indicated and inferred reserves on Park ground. Without the Park reserves available to them, the future of Western Gold's Orphan Lode was in doubt.

Western Gold sought to obtain the Park reserves using extralateral rights. Under the apex law, ore can be legally mined downdip on a lode even if it passes beyond the vertical plane of the side line of a claim. This is not permissable, however, across an end line. Western Gold faced a long and costly legal battle to establish that in the case of the Orphan Lode breccia pipe, the end lines of the claim were actually the side lines. Instead, it sought to negotiate with the Park Service for the ore.

During 1959, development work at the Orphan continued in preparation of starting production through the new crosscut and shaft. On the 245 level, a crosscut was driven from the service winze to the south perimeter of the pipe. Once the annular ring ore was reached, it was explored by drifts. The crosscut from the shaft reached the end line of the claim on the 400 level in August. Drifts were also driven in the annular ring zone on that level. 
A service raise from the 400 level to the 245 level was completed in July, 1959. Other raises from the 400 level to the 245 level were completed in the annular ring zone on the southern perimeter of the pipe. These raises were then used as ore passes to bring ore from the upper levels of the mine to the 400 level where it was trammed to the ore pocket at the shaft and then hoisted to the surface.

Drilling of the $H$ series of core holes on the 175 level resumed and $J, K$, and $L$ series of holes commenced on the 245, 400, and 320 levels, respectively (Table 3). During the summer of 1959, the AEC made a study of the lime content of the orphan Lode ore reserves. The study used shipping records, mine samples, and core assays. It concluded that the remaining reserves in the $A, B$, and $G$ zones averaged below 6 percent $\mathrm{CaCO}_{3}$, those in the annular ring on the claim averaged between 30 and 36 percent $\mathrm{CaCO}_{3}$, and the reserves in the annular $\mathrm{ring}$ in the Park averaged approximately 25 percent $\mathrm{CaCO}_{3}$.

Production via the new shaft began in October 1959, giving the Orphan Lode the capability to hoist 8,000 tons-per-month instead of the 1,000 tons-per-month over the aerial tram. Use of the aerial tram to hoist ore was discontinued once the shaft became operational. In its 1959 report to the stockholders, Western Gold and Uranium reported that it had invested \$1.2 million dollars in the new developments to transform the orphan Lode into a full-fledged mining operation.

With mining operation expanding, Western Gold acquired a site outside the National Park, near the settlement of Tusayan on U.S. 
Highway 180, to build a mobile home park for its employees. This park would be known as Western Village.

In July 1959, Western Gold signed an ore purchase agreement with Rare Metals, that the Tuba City mill would purchase 8,300 tons-per-month of Orphan Lode ore averaging 0.30 percent $\mathrm{U}_{3} \mathrm{O}_{8}$ until the spring of 1962. Western Gold also had an ore purchase agreement with Phillips Petroleum Company to ship 500 tons-permonth to their mill at Ambrosia Lake, New Mexico. The Phillips mill had an alkaline leaching circuit and could treat high lime ores with little difficulty.

Production in 1959 was 26,124 tons of ore averaging 0.56 percent $\mathrm{U}_{3} \mathrm{O}_{8}$ and containing 291,841 pounds of $\mathrm{U}_{3} \mathrm{O}_{8}$ ( $\mathrm{Table}$ 4, Figure 7). Although the tons of ore more than doubled, the contained pounds of uranium oxide only slightly increased over 1958 since the average grade dropped over 50 percent.

In February, 1960, Arizona Senators Hayden and Goldwater introduced Senate Bill S-3094 which would give Western Gold the right to mine the ore in the Park adjacent to the Orphan claim in exchange for the Government acquiring complete title to the claim in 35 years. The AEC approved the bill which would keep northcentral Arizona's uranium industry viable for at least six more years.

In anticipation of the passage of the bill, and receiving a satisfactory allocation from the AEC, Western Gold and Uranium and Rare Metals Corporation of America entered into an agreement that Rare Metals would install an alkaline leaching circuit at Tuba City to treat all ore mined at the Orphan Lode through 1966. The Orphan bill got, however, very little attention by Congress. 
During 1960, exploration drilling of the $J$ and $K$ series of core holes resumed on the 245 and 400 levels respectively. The $M$ and $\mathrm{N}$ series of short core holes, in fan patterns, were begun on the 310 and 350 levels respectively (Table 3 ). The first and only fatality at the Orphan occurred on November 5, 1960 when a skiptender was struck by a descending cage at the main station.

Sinking of an exploration winze from the 400 level to the 550 level began in November, 1960. Progress on the winze was very slow due to heavy ground within the pipe.

Production during 1960 was 77,901 tons of ore containing 473,935 pounds of $\mathrm{U}_{3} \mathrm{O}_{8}$ and averaging 0.30 percent $\mathrm{U}_{3} \mathrm{O}_{8}$ (Table 2, Figure 7). The sharp increase over the previous year was due to the fact that all ore was hoisted through the new shaft and development raises had been completed throughout the lower levels of the mine. During July, the mine set an all time record to date, when 7,733 tons were shipped.

During 1960, shipments of high-lime ore (20 to 30 percent $\mathrm{CaCO}_{3}$ ) to the Phillips mill in New Mexico increased to 1,000 tons-per-month. Low-lime material from the $B$ and $G$ zones was blended with annular ring ore in order to decrease the overall lime content of the ore shipped to Rare Metals, which still averaged about 12 percent $\mathrm{CaCO}_{3}$. The company reported that lime penalties during 1960 averaged $\$ 3.16$ per ton (personal communication, Kofford, M. G., 1961).

The Orphan bill was reintroduced in Congress in January 1961 as 5-383. The earlier bill had died from lack of action in the previous session of Congress. In a move that was called political 
blackmail by some Congressmen, Western Gold released an artists sketch of a luxury resort hotel it planned to build on the claim if the bill was not passed. The 800 room resort would stairstep down the rim of the canyon with a mammoth swimming pool at the bottom. Nevertheless, the proposed plan did alert Congress to the orphan bill.

The exploration winze from the 400 level to the 550 level was completed, and drilling of the $P$ series of core holes commenced for a station of the 550 level in February (Table 3). Thirteen holes were drilled in this series, including P-13, a 1,914 foot deep, vertical hole which bottomed in the Tapeats Sandstone. This hole which began in April, 1961, was completed May 10, 1962 at a reported cost of $\$ 50,000$.

The $R$ series of holes was drilled in the adit level and a new adit was started 150 feet above the original adit to develop ore in the uppermost parts of the pipe (Table 3). Results of this work were largely disappointing, but the drilling did confirm that the pipe, at this level, was more circular than originally thought.

In May, 1961, surface runoff, from heavy rains, entered the adit and flooded the mine. All activity above the 245 level had to cease for several days and when the flooding was all over, there was about a foot of water on the 400 level.

The production goals for the Orphan Lode during 1961 were set at 6,000 tons-per-month averaging 0.28 percent $\mathrm{U}_{3} \mathrm{O}_{8}$, all of the ore being marketed at Rare Metals mill. Blending of the lower grade, low-lime material from within the pipe with the 
higher grade, high-lime annular ring zone continued. In spite of this, the lime content of the April shipment reached an all time record of 20.99 percent $\mathrm{CaCO}_{3}$. By late summer 1961, the $\mathrm{B}$ zone was essentially mined out and the production grade from the $G$ zone was averaging a dissappointing 0.21 percent $\mathrm{U}_{3} \mathrm{O}_{8} \cdot$ The need to acquire the ore in the Park was essential to continue mining at the Orphan Lode.

During August, 1961, the Orphan claim was resurveyed. The original corners Nos. 3 and 4 were located and a small error in the original tie from Corner No. I to the southwest section corner of Section 14 was found. As the result of this modern survey, the claim was found to contain 20.64 acres, instead of the 20.26 acres listed on the original patent (see Figure 33, p. $A-5)$.

Western Gold and Uranium, Inc. was acquired by Lee Ackerman of Scottsdale, Arizona through a stock exchange. Ackerman became President of Western Gold and Uranium on September 6, 1961 and changed the name of the company to Western Equities, Inc. in November.

On December 22, 1961, the ore bin on the headframe of Orphan Lode shaft collapsed sending several hundred tons of ore down the shaft (see Figure 34, p. A-7). There were no injuries and the miners were evacuated via the aerial tram. Damage to the headframe and shaft were estimated to be between $\$ 25,000$ and $\$ 30,000$. The collapse was attributed to a design error of the bin. Mining ceased on December 23, 1961 while the damage was to be repaired. Production during 1961 was 70,289 tons of ore averaging 0.28 percent 
$\mathrm{U}_{3} \mathrm{O}_{8}$ and containing 398,699 pounds $\mathrm{U}_{3} \mathrm{O}_{8}$ (Table 2, Figure 7).

\section{2 - 1966 Productive Years}

Shipments to the Tuba City mill ceased in January 1962, when the surface stockpile at the Orphan Lode was depleted. The mill closed in May 1962 for lack of ore.

On May 28, 1962, President John Kennedy signed into law, Public Law 87-457, which permitted Western Equities, Inc. to mine uranium ore in Grand Canyon National Park, adjacent to the Orphan claim, in exchange for title to the claim in 25 years (1987). The law specified that all mining would be underground and that the tram would be dismantled by 1964. The Federal Government would receive a royalty ranging from 5 to 10 percent on the ore produced. Also, after 1966 only 3 acres in the southeast corner of the claim would be retained for mining. Thus, the Grand Canyon Inn and related cabins would belong to the Park Service in 1967 .

With the ore on the Park ground now available for Western Equities to mine, the AEC negotiated a new contract with El Paso Natural Gas Company, which had acquired Rare Metals by merger in July 1962 (Albrethsen and MCGinley, 1982). A new contract, AT (05-1)-910, was signed on November 19, 1962 and was effective from September 10, 1962 through December 31, 1966 (Albrethsen and McGinley, 1982). Once a new contract was signed, modification of the existing mill to an alkaline leach circuit, using sodium bicarbonate, proceeded rapidly. A flotation circuit was added to remove sulfides which are carbonate consumers. The AEC granted 
Western Equities an allocation of 572,766 pounds of $\mathrm{U}_{3} \mathrm{O}_{8}$ per year under the November 24, 1958 announcement.

On November 20,1962 , mining resumed at the Orphan Lode, with the ore being stockpiled at the Tuba City millsite. Crosscuts to the annular ring deposits were driven on the $245,265,290,320$ and 350 levels to test the ore in the Park. The drift on the 550 level was continued northeastly into the Park. Development of the remaining high lime ore in the annular ring on the claim also commenced. When mining resumed, all ore hoisted up the shaft was stockpiled on the ground, and the use of an ore bin was discontinued.

In April 1963, the Tuba City mill began processing stockpiled Orphan Lode ore. The sulfide flotation concentrate contained sufficient sulfide copper to be marketable at a copper smelter. A small amount of silver was also present in the concentrate. In addition, a small amount of copper solubilized with the uranium, was recovered, using powdered iron, as cement copper in the ion-exchange circuit. Both products were shipped by truck to a smelter at Inspiration, Arizona (Albrethsen and McGinley, 1982). Details of the Tuba City milling circuits are given in a report by Runke (1964).

In the fall of 1963 an incline was driven from the 550 level to the 585 level of the annular ring on the northeastern perimeter of the pipe. This was the lowest level of the deposit to be developed and mined.

During 1963, the Orphan Lode produced 614,858 pounds of $\mathrm{U}_{3} \mathrm{O}_{8}$ (Table 2). Of this total, approximately 47 percent came 
from ore mined on Park ground (Table 5). This would be the second highest yearly production for the mine (Figure 7).

In 1964, a small ore zone on the 375 level of the annular ring on both the claim and Park was developed. The zone was not very productive although it existed almost entirely around the pipe.

Production in 1964 was slightly lower than the previous year, and some 592,047 pounds of $\mathrm{U}_{3} \mathrm{O}_{8}$ were produced (Table 2). El Paso reported to the AEC that in 1964 the orphan Lode ore averaged about 1.30 percent $\mathrm{Cu}$ and that 75 percent of the total copper or 90 percent of the sulfide copper was recovered. The sulfide concentrate averaged 20 percent $\mathrm{Cu}$ and 10 ounces of silver per ton (Albrethsen and McGinley, 1982). No other data on copper or silver production were made available to the AEC by El Paso.

Production from the orphan Lode reached an all time yearly high in 1965 when some 680,746 pounds of $\mathrm{U}_{3} \mathrm{O}_{8}$ were produced (Table 2). Of the total pounds uranium oxide $\mathrm{U}_{3} \mathrm{O}_{8}$, some 75 percent came from the National Park (Figure 7). Ore in the annular ring on the northern side of the pipe, within the Park, proved to be nearly continuous from the 225 to the 365 level. Here, the large No. I stope was developed in bleached, brecciated, and unbrecciated Esplanade Sandstone (Figure 5).

In the early part of 1966, Western Equities Inc. was sold to Geo Space Corporation which was merged into Westec Corporation of Houston, Texas. On August 25, 1966, Westec's stock was suspended from trading on the American Stock Exchange. Westec declared bankruptcy and the Orphan Lode closed again. With its principal 
TABLE 5

Uranium production from the orphan Lode reported to the U. $S$. Atomic Energy Commission as coming from National Park Service ground.

CALENDAR YEAR TONS OF ORE POUNDS $\mathrm{U}_{3} \mathrm{O}_{8} \quad 8 \mathrm{U}_{3} \mathrm{O}_{8}$

\begin{tabular}{|c|c|c|c|}
\hline $\begin{array}{l}1963 \\
1964 \\
1965 \\
1966 \\
1967 \\
1968 \\
1969\end{array}$ & $\begin{array}{c}23,022.61 \\
24,005.38 \\
51,687.15 \\
11,886.42 \\
- \\
23,052.19 \\
-\end{array}$ & $\begin{array}{c}287,143.02 \\
259,513.79 \\
511,768.65 \\
155,458.95 \\
- \\
162,730.63 \\
-\end{array}$ & $\begin{array}{c}0.62 \\
0.54 \\
0.50 \\
0.65 \\
- \\
0.35 \\
-\end{array}$ \\
\hline TOTALS & $133,653.75$ & $1,376,615.13$ & 0.52 \\
\hline
\end{tabular}

Source: U. S. Atomic Energy Commission files, Grand Junction Office 
supply of ore down, El Paso's mill at Tuba City closed in september 1966, three months before its AEC contract was due to expire. The last concentrate from the mill was delivered to the AEC in November 1966 (Albrethsen and MCGinley, 1982).

Production in 1966 was 32,620 tons of ore containing 268,698 pounds $\mathrm{U}_{3} \mathrm{O}_{8}$ and averaging 0.41 percent $\mathrm{U}_{3} \mathrm{O}_{8}$ (Table 2). Nearly 60 percent of the uranium oxide came from the Park ground (Figure 7).

1967 - 1969 Final Years

On August 31, 1967, Westec asked permission from the U.S. District Court in Houston, Texas to sell the orphan claim and related properties to the Cotter Corporation of Roswell, New Mexico and Canon City, Colorado.

During 1967, the Cotter Corporation enlarged its mill at Canon City to process 400 tons per day in an alkaline leaching circuit and 100 tons per day in an acid circuit. A flotation cell was added to remove iron and copper sulfide minerals from the ore prior to alkaline leaching. These sulfides were acidleached to remove uranium before shipment to the smelter (Albrethsen and McGinley, 1982).

Cotter began operating the Orphan Lode in September, 1967 . The first ore was loaded on rail cars at an Atchison, Topeka and Santa Fe Railway Company's siding in Grand Canyon National Park on september 27, 1967, for shipment to Cotter's uranium mill at Canon City, Colorado. Since Cotter's AEC contract had expired on February 28, 1965, all uranium produced after that date was sold on the private market to electrical utilities (Albrethsen and 
McGinley, 1982). Brundy (1977) reported that Cotter paid $\$ 875,000$ in cash for the Orphan claim and Western Village, and that Westec retained a 4.2 percent royalty on ore produced. The Engineering and Mining Journal (1968) noted that the Orphan Lode had 500,000 tons of ore averaging 0.35 percent $\mathrm{U}_{3} \mathrm{O}_{8}$ blocked out when Cotter acquired it.

Production at the Orphan Lode in 1968 was reported to the AEC as 43,147 tons of ore containing 321,174 pounds of $\mathrm{U}_{3} \mathrm{O}_{8}$ and averaging 0.37 percent $\mathrm{U}_{3} \mathrm{O}_{8}$ with nearly equal amounts coming from the claim and the Park (Figure 7).

The Orphan Lode closed for the final time on April 25, 1969. The shut down was attributed to a freight charge of $\$ 12.96$ per ton to transport the ore, by rail, some 750 miles from Grand Canyon to Canon City (Pay Dirt, 1969).

After the mine closed, the AEC estimated that 500,000 pounds of uranium oxide remained in the mine in low grade material averaging 0.11 percent $\mathrm{U}_{3} \mathrm{O}_{8}$. All of this estimated uranium was above the 400 level, and the majority of it was within the pipe ( $B$ and $G$ zones).

Figures 8 through 24 show the extent of the mine workings on the different levels after mining had ceased. 
Epilog

The dramatic increase in the price of uranium in the mid 1970's renewed interest in the orphan Lode. The Cotter Corporation conducted several feasibility studies concerning the reopening of the mine. At one time an upgrading plant was considered in the Williams, Arizona area. Environmentalists sought to prevent ore trucks from ever again moving through the National Park. After evaluating all possibilities, the orphan Lode remained closed.

The Western Village site had become very valuable real estate. Records of the Coconino County Assessor's office show that on February 18, 1981, John R. Siebold of Grand Canyon, Arizona and Elling Halvorson of Redmond, Washington acquired the Western Village site and the orphan claim. They reportedly paid the Cotter Corporation $\$ 800,000$ for the property.

The Federal Government will receive complete title to the Orphan claim on May 28, 1987, when the last 3 acres are transferred. By that time, the remaining mine buildings and headframe will have been removed, and the orphan Lode will be history. 


\section{Production Summary}

Records of the AEC show that during the period 1956 through 1969 the Orphan Lode Mine produced 495,106.63 dry tons of ore containing $4,257,571.47$ pounds of uranium oxide and averaging 0.43 percent $\mathrm{U}_{3} \mathrm{O}_{8}($ Table 2$)$. Other production statistics are given in Table 6 . It is possible that the cotter corporation did not report all of their production to the $\mathrm{AEC}$, hence a difference of 5,325 tons containing 28,683 pounds $\mathrm{U}_{3} \mathrm{O}_{8}$ with an average grade of 0.27 percent $\mathrm{U}_{3} \mathrm{O}_{8}$ between their records and the AEC's. The source of Scarborough's figures (Table 6) is a U.S. Department of Energy computer listing which is known to contain numerous errors, resulting from the 1969 production being added twice. Cotter officials estimated the value of the uranium produced at $\$ 40$ million (Pay Dirt, 1969). Of the total uranium oxide produced, some 1,376,615 pounds, or 32 percent came from ore bodies in Grand Canyon National Park (Table 5).

The vanadium content of the Orphan Lode ores was determined at Tuba City and the contained vanadium oxide was paid for under the terms of the AEC's Circular 5, Revised. Since this practice was for carnotite type ores, it was discontinued on the Orphan uraninite ores after March 1958 (Table 4). According to AEC records, some 3,283 pounds of $\mathrm{V}_{2} \mathrm{O}_{5}$ were paid for, but never recovered at Tuba City.

Information on the copper and silver content of the Orphan Lode ores is very meager. Scarborough (1981, p.157) has published that 6.68 million pounds of copper and 107,000 ounces of silver were produced. The source of this information was in the Arizona 
Page 44

TABLE 6

Comparison of production statistics from the Orphan Lode Mine, Coconino County, Arizona.

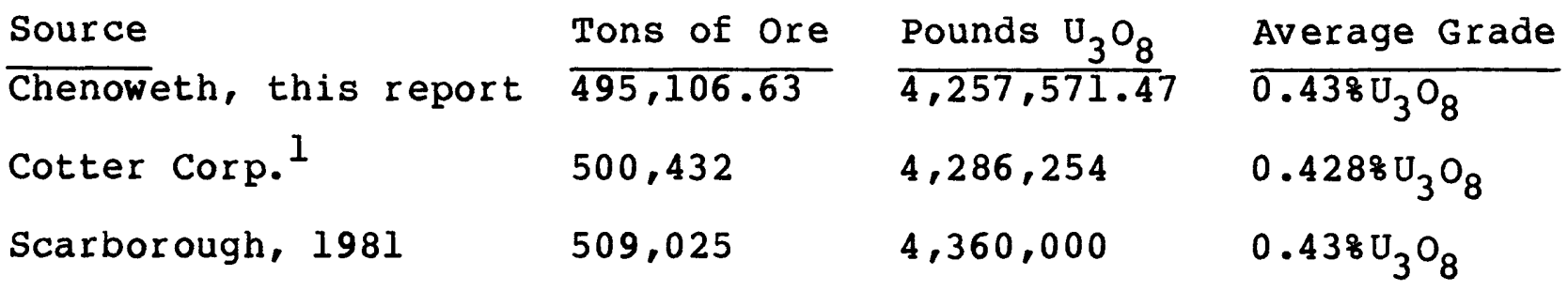

1 Personal communication from Erik W. Bruner, 1985. 
Bureau of Geology and Mineral Technology files (R.B. Scarborough, oral communication, 1985). Ore production from 1962 through 1969 was 222,910 tons when the copper and silver were recovered. Since these ores ranged in grade from 1.10 to 1.50 percent copper, and 0.35 to 0.45 ounces per ton silver, Scarborough's statistics appear reasonable.

\section{MINING METHODS}

The Orphan Lode had two different phases of mining depending on how the ore was transported to the canyon rim. The initial phase used an aerial tram, and the second was through a vertical shaft.

Initial production was in April 1956. Until October 1959, all ore was transported to the canyon rim using the aerial tram. Production of the mine was limited by the capacity of the tram, not by the developed ore in the mine. In the early years of the mine there were 4 levels below the adit level - 100, 140, 175 and 245 (Figure 6). On each of the levels, ore was broken at the face, loaded into mine cars, hand trammed to the service winze, hoisted, and hand trammed out the adit level to the mine portal. Here, the ore was dumped into a car on an inclined track which was hoisted and dumped into ore bins on the lower terminal of the tramway. At the lower terminal, the tram buckets were loaded and hoisted to the rim and dumped into bins on the upper terminal. Trucks were loaded from the bins for haulage to Tuba City, Arizona.

As exploration and mining developed in the high grade $A$ ore body, all the ore from that zone was dropped to the 245 level through ore passes. Here, it was loaded into $16 \mathrm{cu}$. ft. capacity 
ore cars and hoisted up the service winze to the adit level to be put in ore bins at the lower tramway terminal. Stoping eventually connected all 5 levels (adit, 100, 140, 175, and 190) and the large A Stope was formed.

In late 1959, when the new shaft and crosscut to the 400 level were completed, mining methods at the orphan changed. Ore within the pipe ( $B$ and $G$ zones), and the annular ring ore bodies were mined by different methods.

The massive ore body of the B zone was broken with long holes drilled horizontally from vertical raises located in, or at the edge, of the ore. The high grade shaft pillar of the service winze was removed and backfilled with waste to keep this access to the adit level open. No timbering or roof bolts were necessary in the large stopes as the walls stood well. Ore from the B zone was collected in ore pockets on the 265 level and eventually dropped to the 400 level via ore passes (Figure 5).

To mine the $G$ zone, a slot stope was cut adjacent to the north end line of the claim between the 290 and 320 levels. Additional slots were cut, and $G$ zone was mined from the 265 to the 365 levels. Ore was blasted into the slots and collected on the 365 level (Figure 5). From here it was passed to ore pockets on the 400 level. The large scale stoping in the $G$ zone produced a grade of ore that was much lower than anticipated.

Ore in the annular ring on the claim was developed by untimbered drifts on the 245,310 and 350 levels, which circumscribe the pipe on the claim. Raises from the 245 level to sublevels on the 190 and 225 also developed ore on the claim in the annular ring. A subdrift on the 285 level was used to mine a small ore body 
which occurred above a barren muastone bed on the southern perimeter of the pipe. Underhand stoping developed a large open stope between the 310 and 350 levels on the soutnwest perimeter ot the pipe (Figure 28). The nigh lime content of the annular ring zone permitted the drifts and stopes to stay open without timbering or root bolting. The cut and fill method of mining used in the annular ring permitted the disposal of a $\perp$ waste rock underground.

When the ore in the National Park became available, it was developed by crosscuts trom the area ot the service raise (trom the 400 level) to the perimeter ot the annular ring on the 245, 265, 290 and 320 levels. Dritts from the existing workings in the claim were extended into the Park ground on the $225,350-365$ and 400 levels. The ore in the Park portion of the annular ring proved to nave a greater vertical continuity than on the Orphan claim. As a result, the large No. I Stope was developed between the 225 and 365 levels (Figure 5).

Slushers and hand tramming were used to move ore to transter raises where it was aropped to ore pockets on the 400 level. Here, the ore was loaded into 2.5 ton capacity Card RD-40 cars and was trammed to the shatt station by a Mancha battery-powered locomotive. At the station ore was side dumped into a slusher trench where 1 t was loaded into $2 \frac{1}{2}$ ton skips and hoisted to the surtace. At the surtace ore was stored in a bin attached to the neadtrame, but beginning in 1962 it was stored on the ground near the shatt.

Ore in the annular ring zones below the 400 level was developed and mined by aritts on the 420-430, 525 and 585 levels. Ore 
on the 420-430 and 525 levels was dropped through ore passes to the 550 level, and the ore from the 585 level was hoisted up the incline to the 550 level by use of a tugger. From the 550 level, ore was hoisted up the winze to an ore pocket on the 400 level, for storage before it trammed to the shaft station.

The mine was dry, all water used at the mine, as well as the Grand Canyon Inn, had to be hauled from Williams, Arizona, a distance of 60 miles. In wet weather some seepage water was caught and utilized by the mine.

\section{URANIUH GEOLOGY}

\section{The Breccia Pipe}

The Orphan Lode deposit is associated with a nearly circular, vertical breccia pipe that crops out in the Grand Canyon near the Coconino Sandstone - Hermit Shale contact (Figure 3).

At the adit level the pipe has a mean diameter of about 220 feet, within the Hermit Shale. Just below the 175 level, within the Esplanade Sandstone of the Supai Group, the pipe flares, and at the 350 level the mean diameter is about 400 feet. From the 175 to the 400 level, the pipe's configuration in section is partly controlled the lithology of the Esplanade. The diameter of the pipe increases in sandstone beds and decreases in siltstone and mudstone units. The pipe is notably constricted at the 400 level in a thick silty sandstone in the Wescogame Formation of the Supai Group. Below this level, drilling has indicated that the diameter increases to over 500 feet. The boundary of the pipe is marked by a set of concentric, circular fractures that form a sheared and brecciated zone. 
All sediments in the pipe have been displaced downward from their normal stratigraphic position outside the pipe. The youngest rocks in the pipe are sandstones of the Coconino Sandstone. Rocks of Coconino lithology have been displaced downward a minimum of 370 feet.

The upper part of the pipe contains a sandstone fill that was derived from the Coconino Sandstone. It consists of white to buff, fine-grained, quartzose sandstone. This sandstone fill has been found in the pipe to the 245 level. Blocks of claystone breccia are also present in the upper part of the pipe.

Below the 245 level, the pipe fill consists predominantly of a claystone breccia, probably derived from the Hermit Shale. Sandstone fill in the lower levels of the mine was probably derived from the Esplanade Sandstone, and not the Coconino Sandstone as believed by Gornitz and Kerr (1970). Angular blocks of siltstone and sandstone are also common in the lower levels of the mine.

The exploration winze from the 400 to the 550 level penetrated a poorly cemented breccia of angular blocks of sandstone, siltstone, and limey siltstone in a matrix of claystone, siltstone and clay. The breccia blocks within the pipe although displaced downward from their normal stratigraphic position show remarkably little evidence of jumbling and mixing in some areas of the mine. Breccia blocks range in size from huge blocks several yards across to pieces less than one inch.

Nearly all of the rocks within the pipe have been altered from their original reddish hues to white, gray, and brownish hues. Large blocks of Supai sandstone in the lower levels of the 
mine exhibit alteration only on the outer 2 to 3 inches of their surfaces; whereas the center part of these blocks are still red in color. Samples from a horizontal core hole, drilled on the 550 level, also showed reddish colored sandstone within the pipe (see Page $\mathrm{A}-30$ ).

\section{Ore Deposits}

Uranium ore deposits at the Orphan Lode occur in two distinct geologic environments - 1) within the pipe fill, and 2) associated with the peripheral shear zone surrounding the pipe. The latter has been termed the annular ring by company geologists and engineers. Average uranium production grades for small areas of the mine are shown in Figures $25,26,29$, and 31 . No other production grade maps were available to the writer.

Principal ore bodies within the pipe include the $\mathrm{A}, \mathrm{B}$, and $\mathrm{G}$ zones (Figure 5). The A ore body, or zone, occurs in the northeast part of the pipe at the adit level and extends downward to about the 190 level. It reached a maximum width of 40 feet on the 175 level. This was a very high grade ore body (greater than 1.50 percent $\mathrm{U}_{3} \mathrm{O}_{8}$ ) which consisted of uraninite disseminated throughout a poorly consolidated sand derived from the Coconino Sandstone. The high grade ore from the A stope was the principal source of the Orphan production in the early years. The shape of the ore body was controlled by the distribution of the coconino sand fill within the pipe. The northeastern limit of the fill was marked by the peripheral shear zone of the pipe within the Hermit Shale.

The B ore body, or zone, extended from about 30 feet above the adit level downward to the 245 level (Figure 5). The principal 
area of mining was from the 140 level to the 245 level where the ore body was mined to a diameter of about 200 feet. This large ore body consisted of some very high grade (greater than 1.00 percent $\left.\mathrm{U}_{3} \mathrm{O}_{8}\right)$ pods surrounded by lower grade and barren material (Figure 25). Host rocks for the B zone included coconino sand fill as well as a claystone breccia. Calcified blocks of argillic breccia, resembling limestone, were mined on the 175 level in 1957, when the lime content of some shipments to Tuba City reached 14 percent $\mathrm{CaCO}_{3} \cdot \mathrm{A}$ combination of increased permeability and fracturing appear to have been important in localizing the B ore body. Pyrite was very common in the B ore body, especially in the lower part. A sample of high grade uranium ore containing abundant sulfide minerals was collected by E.W. Grutt, Jr. in 1959 from the B zone on the 245 level (Figure 29). This sample (USGS 991-L-C85) was located during this research project and donated to the Geological survey for study.

The G ore body, or zone, is essentially a downward continuation of the B ore body. Below the 245 level the ore in the center of the pipe rakes to the northeast and continues downward to the 365 level (Figure 5). The ore body was similar to the $B$, but not as high grade (Figure 26). It was mined between the 265 and 365 levels and the $G$ stope reached a maximum mean diameter of 160 feet on the 320 level. Breccia derived from the Hermit shale and the Esplanade Sandstone, as well as some sand fill from the Esplanade, seem to be the host rocks for the G ore body. 


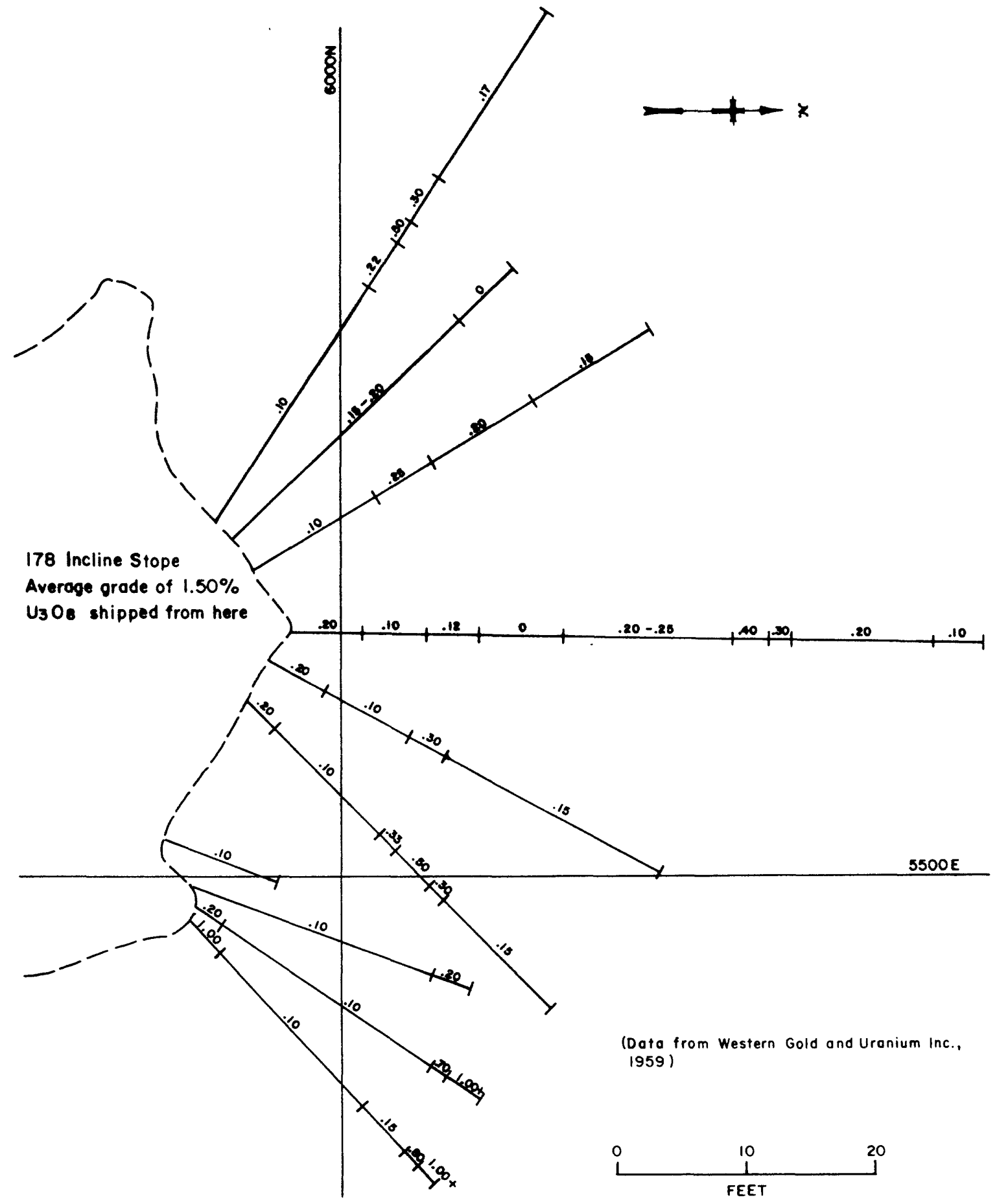

Figure 25. Uranium grade distributions from ore shipments and ionghoid drilling, B Zone 


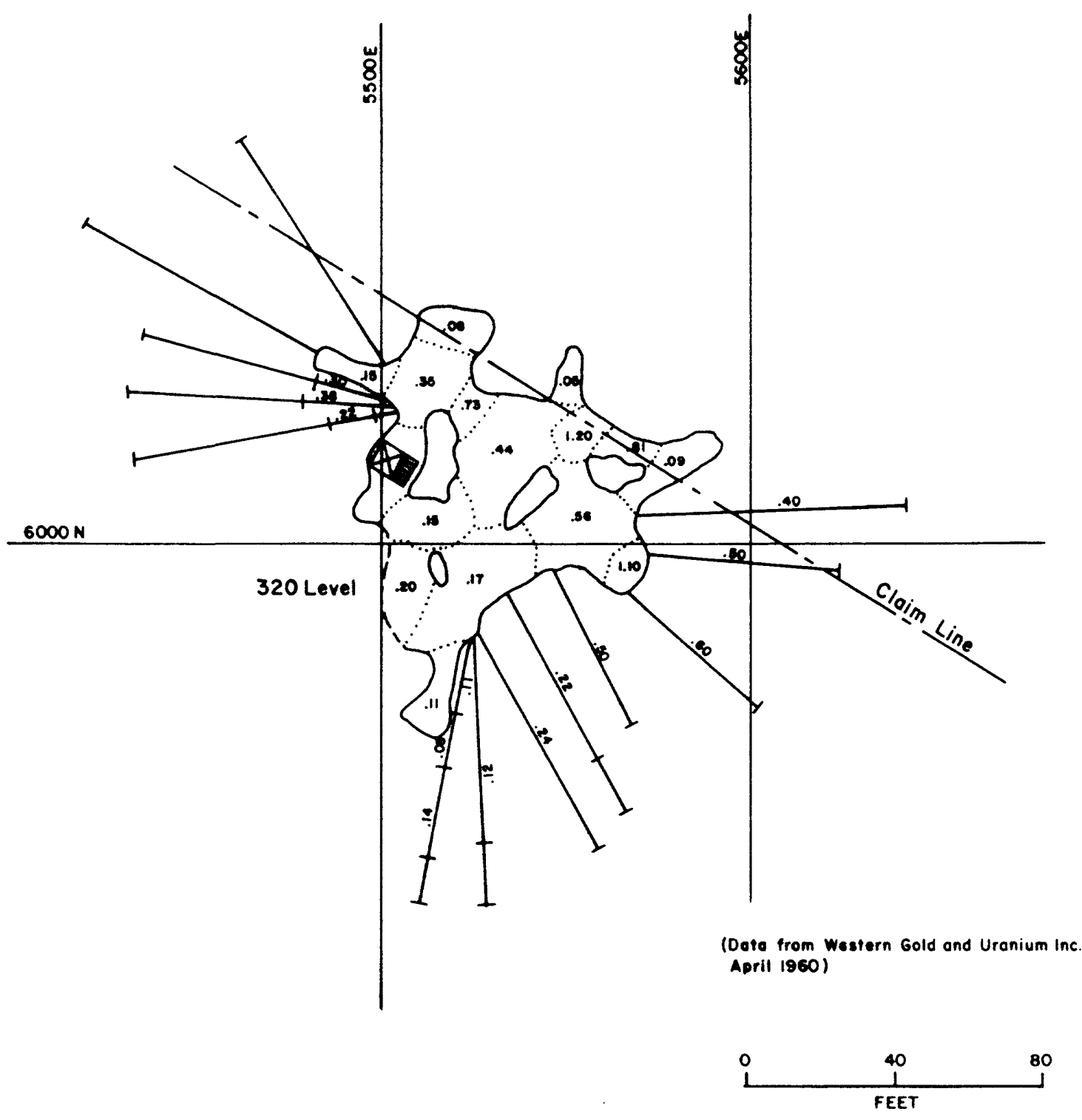

Figure 26. Uranium grade distributions from ore shipments and longhole drilling, G Zone 
Ore stringers from the $B$ and $G$ zones coalesce with the annular ring ore bodies in the northern portion of the pipe, below the 175 level. Small pods of ore have been mined on the 245, 265, 290,320 , and 365 levels. The host rocks for these small pods were largely calcified sandstone-pipe-fill possibly derived from the Esplanade Sandstone.

Ore bodies in the annular ring can occur - 1) within the peripheral shear zone, 2) within collapsed pipe-fill materials adjacent to the shear zone, and 3) in undisturbed sediments outside the shear zone. The most of the ore produced from the annular ring came from deposits in the Esplanade Sandstone outside the shear zone (Figure 5). Here, ore occurs in sandy beds in relatively undisturbed sediments outside of the pipe. Vertical, arcuate faulting appears to control the radial extent of the ore beyond the pipe; the width of the ore bodies varies from 6 to 60 feet. Clay and mudstone lenses or beds in the annular ring are barren, and some sandy units are also barren. No megascopic differences have been noted between the mineralized and nonmineralized sandy sections. The ore is continuous horizontally in the favorable sandy sections around the entire periphery of the pipe, but the vertical continuity is interrupted by unfavorable beds (Figures 27 and 28). Kofford (1969) has compared the annular ring to a stack of washers, with the alternate ones being ore bearing.

The annular ring on the claim has been mined on the 190, 225, $245,285,310,350,375$, and 420 levels. The ore bodies are generally about 15 feet wide, but reached a maximum width of 60 feet on the 350 level. The 310-350 level was very productive on 


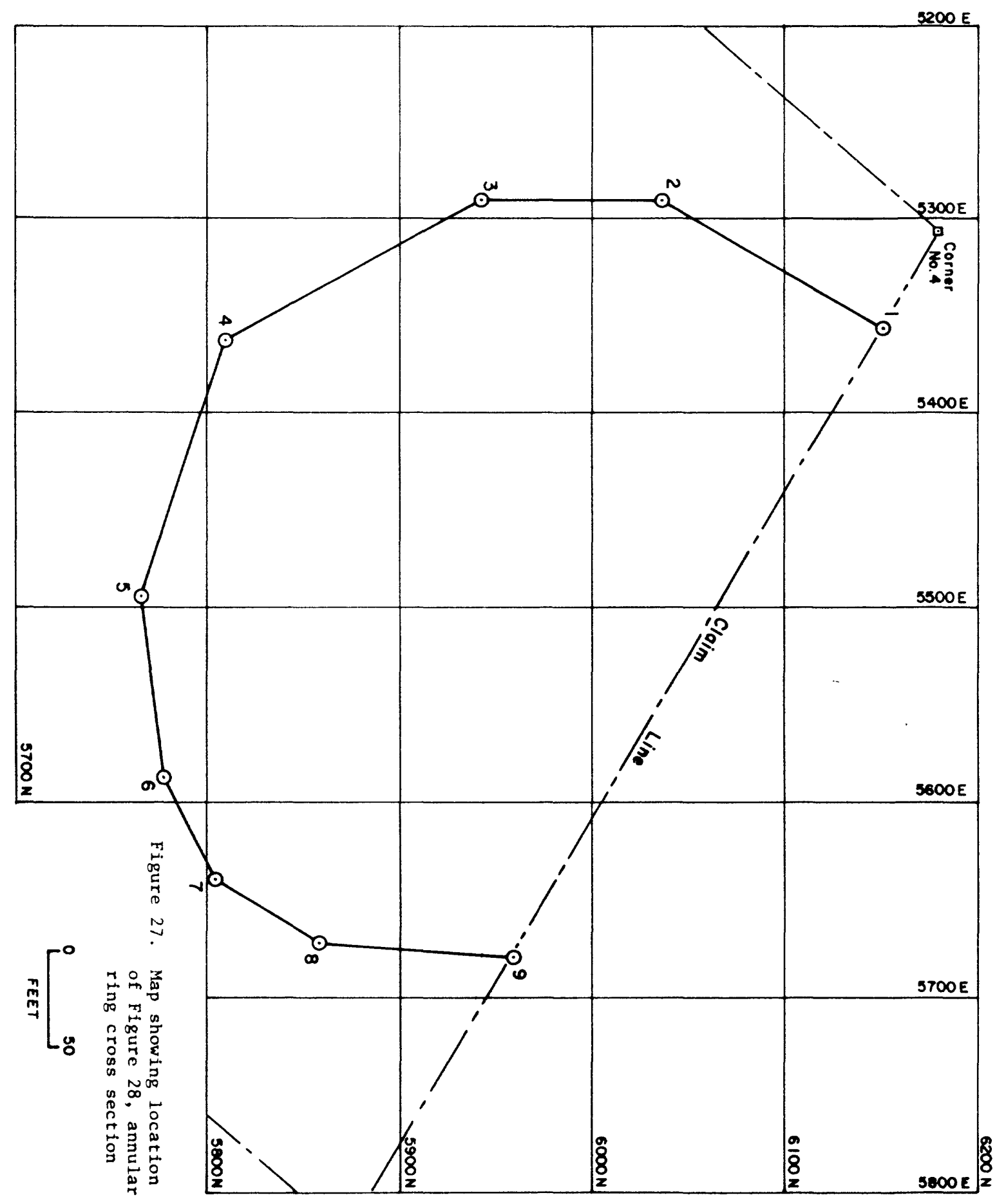




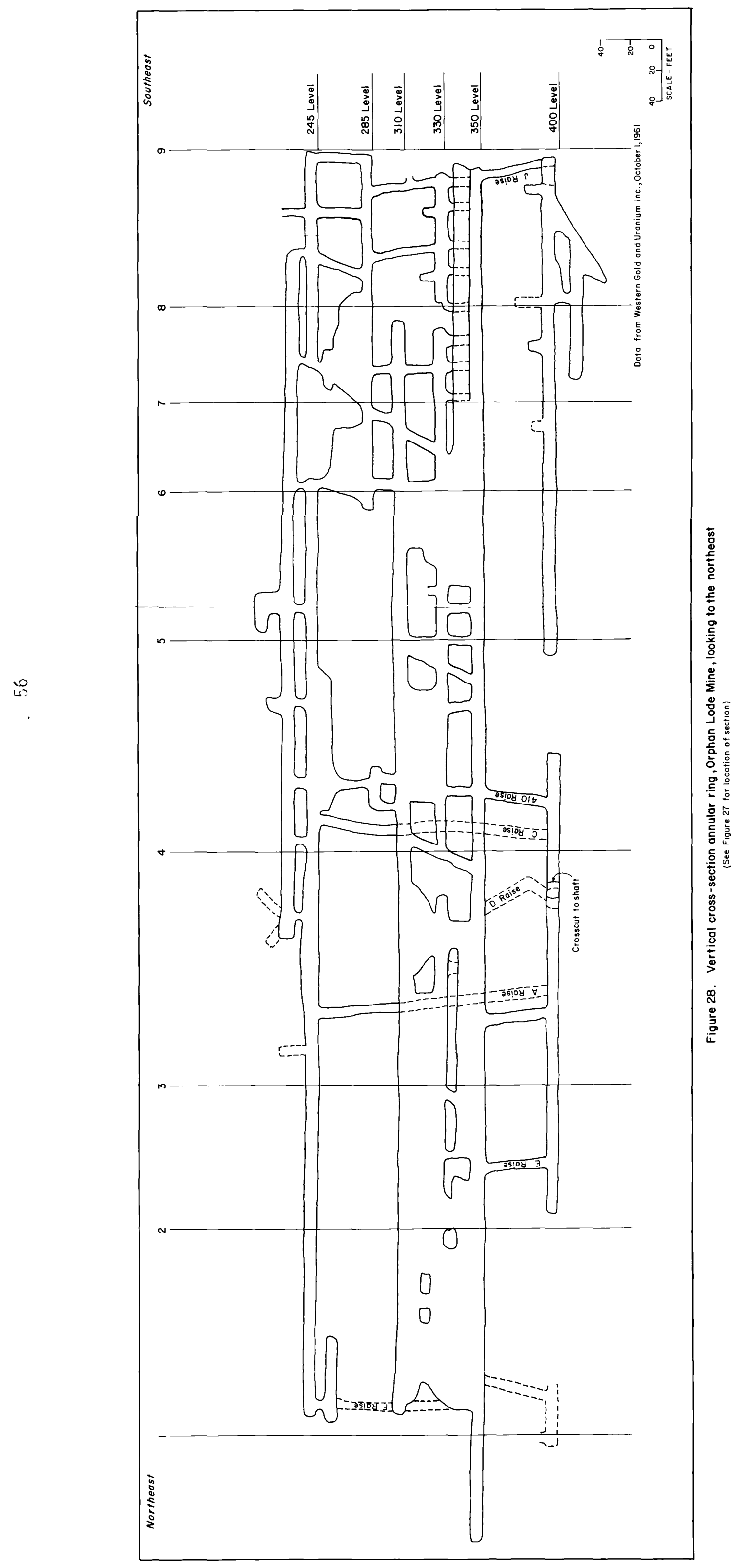


the claim. Ore was continuous between the two levels on the northwestern segment, but was separated into two levels by 7 to 10 feet of barren mudstone on the south and southeast segment (Figure 28). The bottom of the $310-350$ ore zone in the claim is marked by a mudstone bed.

On the northern perimeter of the pipe, in the National Park, the separation between the different ore levels is not distinct. The intense shearing on the pipe boundary here has resulted in a good vertical continuity of the ore bodies. The early drilling detected this continuity and this part of the annular ring was termed "the feeder zone" (Kofford, 1969). The massive ore body in the Park was mined out by the No. 1 stope (Figure 5) which extended from the 225 level to the 365 level. This stope had an average width of about 50 feet, with a maximum width of 200 feet on the 320 level.

Ore in the annular ring below the 400 level is localized in sandstone beds of the Wescogame Formation of the Supai Group. Ore bodies have been mined on the 420-430, 525, and 585 levels, but these ore bodies did not have the horizontal continuity of those in the Esplanade Sandstone. The $P$ series of holes (Table 3) was unsuccessful in locating additional ring zones below the 585 level.

Bleached Supai sandstones outside the pipe are very common. Sandstones that are normally dark reddish-brown, are white, light gray to pinkish gray near ore. Both increased permeability and fracturing have localized ore within the Supai sandstones. Remains of land plants in the Esplanade Sandstone are uncommon (Mckee, 1982, p. 98). On the 245 level, near the C raise (Figure 29), 
the author observed a small accumulation of plant fragments that were mineralized with uranium (Figure 30 ). Although rare in the Orphan Lode, this occurrence was similar to other organic-materialrelated uranium deposits on the Colorado Plateau.

An envelope of introduced calcite cement extends completely around the pipe from about the 190 level to beyond the 585 level and possibly to the lower limit of the pipe. This envelope, which is largely outside the peripheral shear zone, can reach a maximum width of 60 feet and is responsible for the so-called high lime ore at the orphan.

\section{Mineralogy}

The mineralogy of the orphan Lode has been described by Kofford (1969) and Gornitz and Kerr (1970). The only additional information this report can contribute is in the appended petrographic reports (Pages A8-Al8), and in little known reports by Lynch and Viklund (1956) and Runke (1964).

Most of the samples collected by the author and other AEC geologists were submitted for semiquantitative spectrographic analysis. Unfortunately none of these results could be located during the research for this report. All of the analytical data that was located in the old AEC files at the Grand Junction Projects Office of the DOE is included in the appendix. 


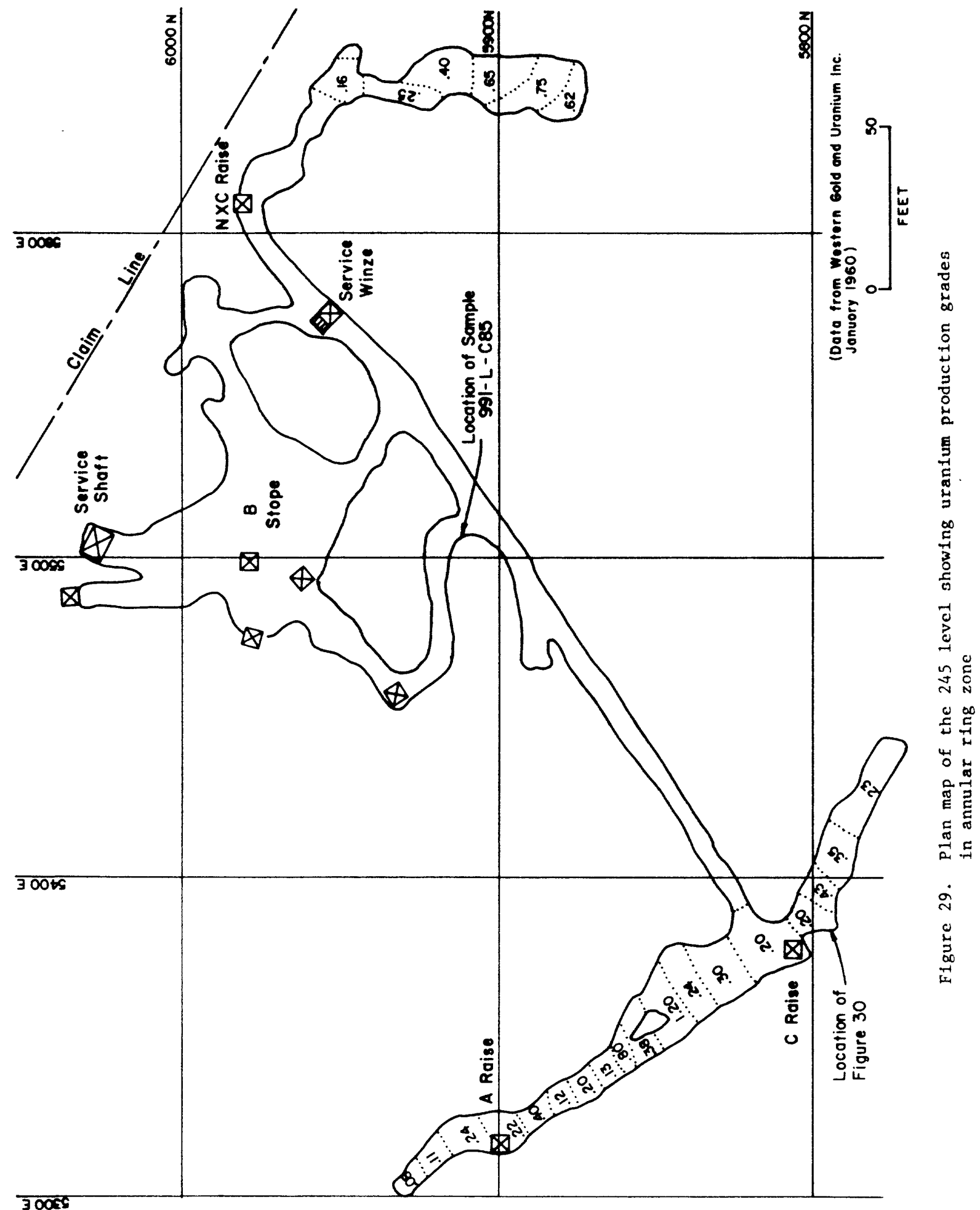


Page 60

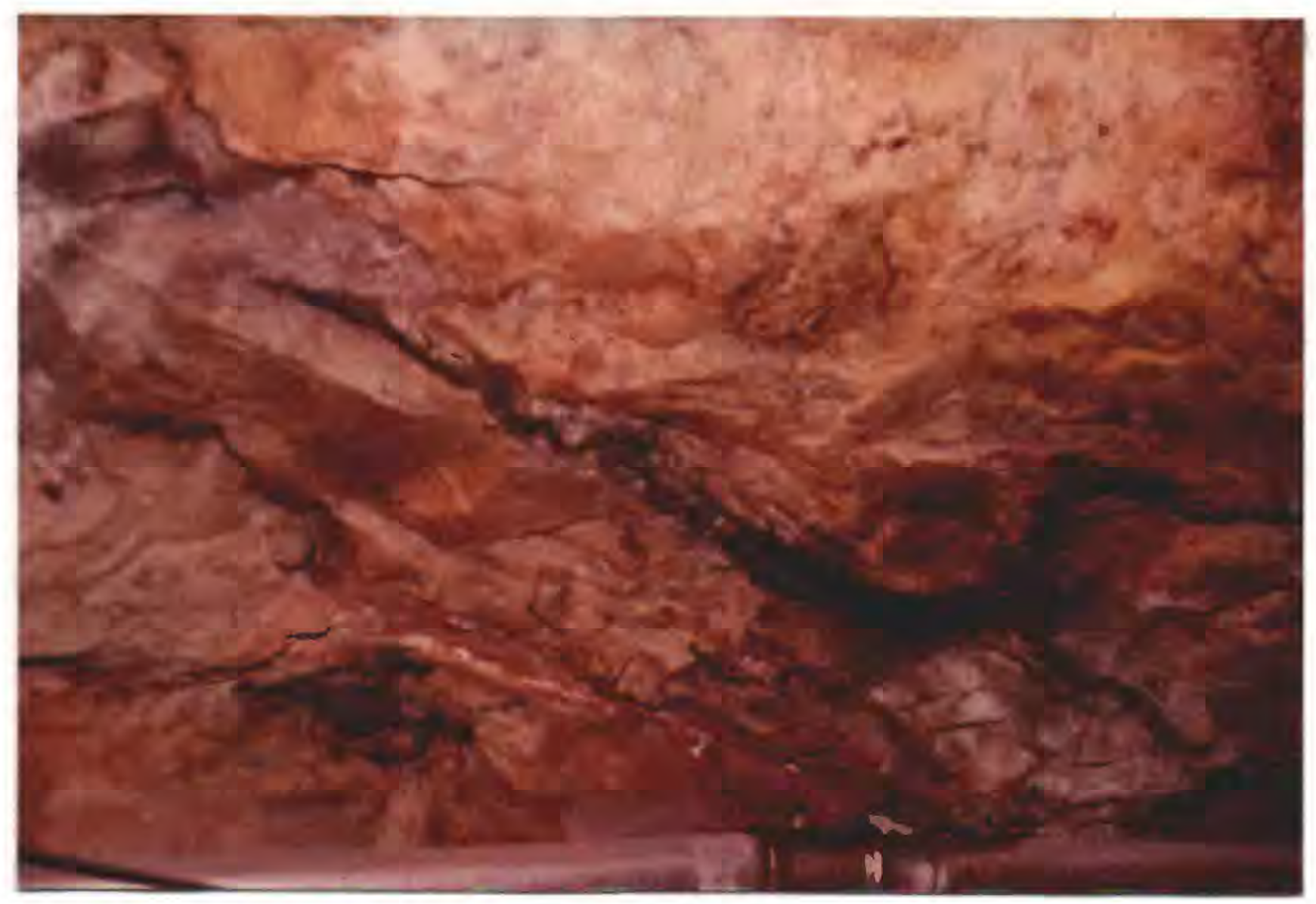

Figure 30, Color photo of mineralized fossil plant material in the Esplanade Sandstone, 245 level near C Raise. Photo by W. L. Chenoweth 
Samples from various drill holes were routinely analyzed for radiometric disequilibrium for resource estimates. Analytical data on a 350 pound sample from the old Hogan adit is given in Table 7, and data on composite samples from monthly ore shipments is in Table 8 .

Most of the ore-related minerals occur as finely disseminated fillings and coatings that require laboratory identification. The most common uranium mineral is sooty uraninite. Torbernite and metazeunerite are common secondary minerals. Carnotite and/or tyuyamunite was the prominent uranium mineral in a large composite sample from the adit level (Lynch and Viklund, 1956, p.6). Some of the readily identifiable non-uranium minerals observed are calcite, gypsum, pyrite, chalcopyrite, chalcocite, covellite, limonite, hematite, galena, sphalerite, tennantite, tetrahedrite, and copper carbonates. 
TABLE 7

Analyses of a composite 350 lb. sample from the Adit level, Orphan Lode Mine.

$\frac{\text { Constituent }}{\mathrm{U}_{3} \mathrm{O}_{8}}$

$\mathrm{Fe}$

$\mathrm{CaO}$

MgO

$\mathrm{Al}_{2} \mathrm{O}_{3}$

$\mathrm{V}_{2} \mathrm{O}_{5}$

$\mathrm{SO}_{4}$

$\mathrm{SiO}_{2}$

Chemical Analysis

\begin{tabular}{cc} 
Percent & Constituent \\
\hline 0.217 & $\mathrm{P}_{2} \mathrm{O}_{5}$ \\
2.80 & $\mathrm{CO}_{2}$ \\
6.50 & $\mathrm{Cu}$ \\
2.22 & $\mathrm{~Pb}$ \\
8.98 & $\mathrm{Ti}$ \\
1.51 & $\mathrm{Ag}$ \\
0.35 & $\mathrm{Au}$ \\
72.95 &
\end{tabular}

$\frac{\text { Percent }}{0.20}$

0.64

0.81

0.10

0.22

$3.6 \mathrm{oz} / \mathrm{ton}$

Trace

Semiquantative Spectrographic Analysis

\section{Constituent}

Ag

A1

B

$\mathrm{Ba}$

$\mathrm{Bi}$

$\mathrm{Ca}$

Cd

Cr

$\mathrm{Cu}$

$\mathrm{Fe}$

$\mathrm{Ga}$

$\mathrm{L} i$

Mg

$\mathrm{Mn}$

\begin{tabular}{c} 
Percent \\
\hline $\mathrm{mt}$ \\
$\mathrm{M}$ \\
$\mathrm{mt}$ \\
$\mathrm{m}$ \\
$\mathrm{m}$ \\
$\mathrm{Mm}$ \\
$\mathrm{mt}$ \\
$\mathrm{mt}$ \\
$\mathrm{Mm}$ \\
$\mathrm{M}$ \\
$\mathrm{m}$ \\
$\mathrm{m}$ \\
$\mathrm{Mm}$ \\
$\mathrm{m}$
\end{tabular}

m
Constituent

Mo

Co

$\mathrm{Na}$

$\mathrm{Ni}$

$P$

$\mathrm{Pb}$

$\mathrm{Sb}$

$\mathrm{Si}$

Sn

Sr

Ti

$\mathrm{V}$

Zr
Percent

mt

mt

Mm

mt

$\mathrm{Mm}$

$\mathrm{Mm}$

m

MM

mt

$\mathrm{Mm}$

$\mathrm{Mm}$

M

m

Code: $\quad M M=$ above 108

$$
\begin{aligned}
M & =108 \text { to } 18 \\
M & =18 \text { to } 0.18
\end{aligned}
$$

$$
\begin{aligned}
& \mathrm{m}=0.18 \text { to } 0.018 \\
& \mathrm{mt}=0.018 \text { to } 0.0018 \\
& \mathrm{t}=\text { below } 0.0018
\end{aligned}
$$

Analysis by National Lead Co. From Lynch and Viklund (1956) 
Page 63

\section{TABLE 8}

Chemical analysis of composite ore samples, representing monthly shipments, Orphan Lode Mine.

Constituent

$\mathrm{U}_{3} \mathrm{O}_{8}$

$\mathrm{Cu}$

$\mathrm{V}_{2} \mathrm{O}_{5}$

Mo

$\mathrm{CaCO}_{3}$ *

$\mathrm{CO}_{3}$ **

$\mathrm{SO}_{4}$ **

Sulfide $S$

Organic C
High Grade Ore Percent

1.00

1.50

0.01

0.04

25.00

35.00

1.50

7.70

0.12
Low Grade Ore Percent

$$
0.35
$$

0.75

0.01

0.02

15.50

20.00

0.70

3.80

0.70

* Acetic acid titration method.

** LECO furnace method.

From Runke (1964) 
Pyrite is abundant through the interior of the pipe. Within the annular ring ore bodies, copper minerals occur in a low grade uranium ore zone inside the higher grade uranium zone (Figure 31). This zoning was best observed by the author in the 310-350 levels in the claim. Similar zoning in the Park ore was observed by E.W. Bruner (oral communication, 1985) on the 225 level. Although this zoning was first recognized by the mine geologists and observed by the author, the copper-uranium relationship does not appear in the analysis of composite ore shipments at the mill (Table 8). This is probably due to the fact that all ore in the annular ring was mixed and shipped as "high lime ore", and the B and G zone ores were shipped as "low lime ore". Chalcocite appeared to be more abundant than chalcopyrite in the upper levels of the annular ring (225-190), whereas chalcopyrite was common in the lower levels $(350-245)$. Copper minerals in the annular ring are scarce below the 350 level. Below the 400 level pyrite is common in the annular ring.

Earthy red hematite was observed with high grade uraninite ore in the annular ring, and in the $A$ zone. It was especially abundant in the northeast part of the annular ring on the 400 level. A typical sample collected by the author from the northeast end of the 400 crosscut was located during this study and submitted to the Geological Survey (No. 999-0-C86).

Analysis of a composite sample from the adit level indicated a silver content of 3.5 ounces per ton (Table 7). This is rather anomalous in view of the fact that the cotter Corporation estimated that total ore production from the mine averaged 0.40 ounces 


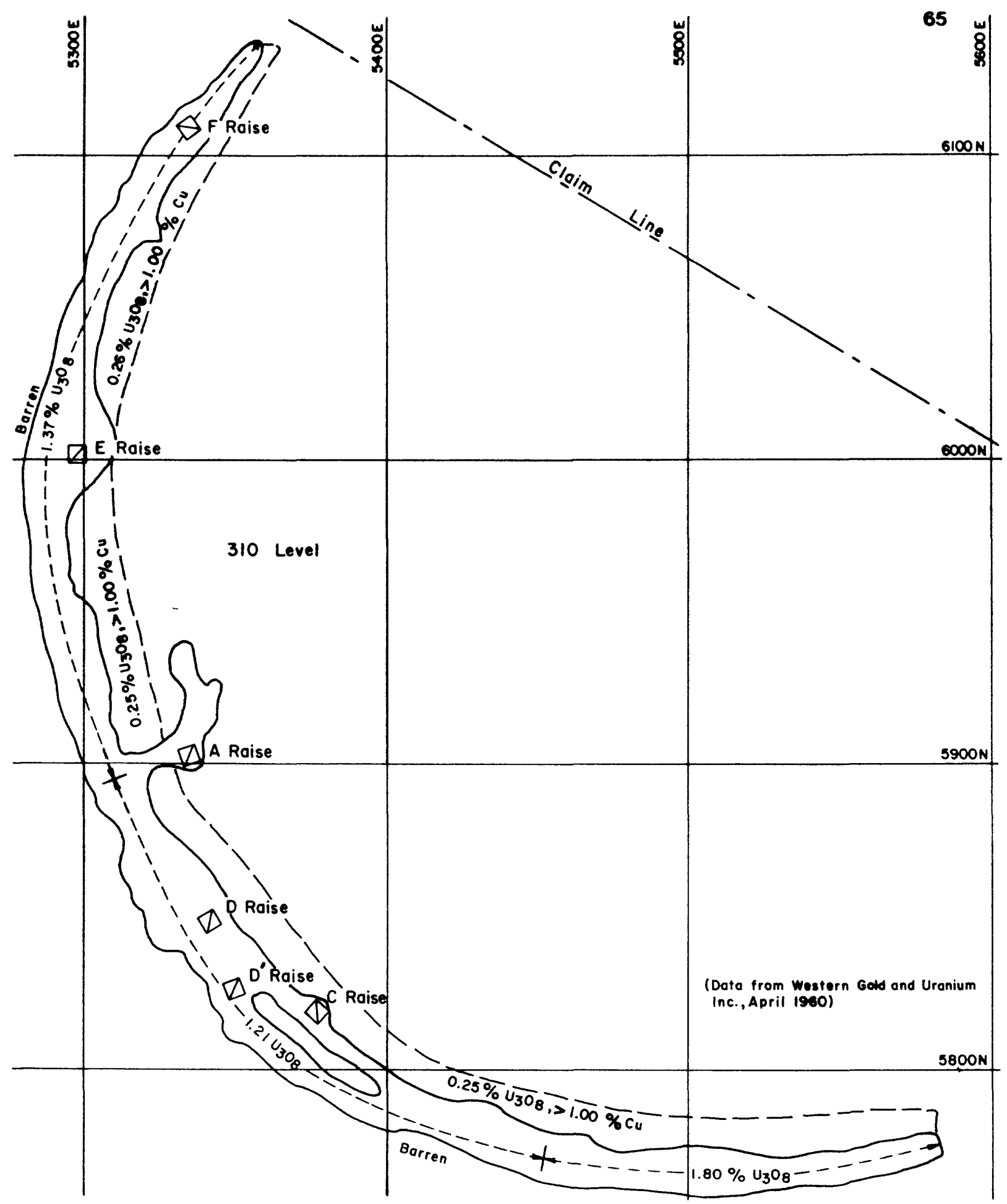

Figure 31. Map of annular ring zone on 320 level showing average uranium production grades, and inferred ore blocks from longhole drilling 
per ton (E.W. Bruner, written communication, 1985). The high value in adit level may be the result of supergene activity.

Oxidation has been noted on all levels of the Orphan Lode Mine. It is most abundant in the adit level where secondary yellow uranium minerals are profuse. Some oxidation is the A zone was observed on the 175 level. Here, W. R. Ashwill of the AEC, collected a sample of secondary uranium minerals in 1957. This sample (USGS No. 991-Q-C86) was located during this study. The majority of the ore in the $A$ zone was uraninite disseminated in the Coconino sand fill. A typical sample collected by the author on the 100 level also was located (USGS No. 991-M-C86).

In the annular ring ore zones, limonite staining, up to several inches wide, occur on both sides of fractures (Figure 32). This staining occurs along the entire vertical extent of the exposed fractures. The oxidation observed in the orphan Lode Mine is no doubt related to the cutting of the Grand Canyon by the Colorado River during the Tertiary which breached the water tables in the supai and Redwall rocks.

Sand fill and breccia within the pipe have been locally cemented with coarse-grained calcite and dolomite. An envelope of calcite cemented sandstone is present around the pipe in the annular ring. M.G. Kofford (written communication, 1959) believed that there were two different ages for the introduction of the carbonates. He considered the carbonates within the pipe to be older than those in the annular ring. Gornitz and Kerr (1970) reached a similar conclusion. 
Page 67

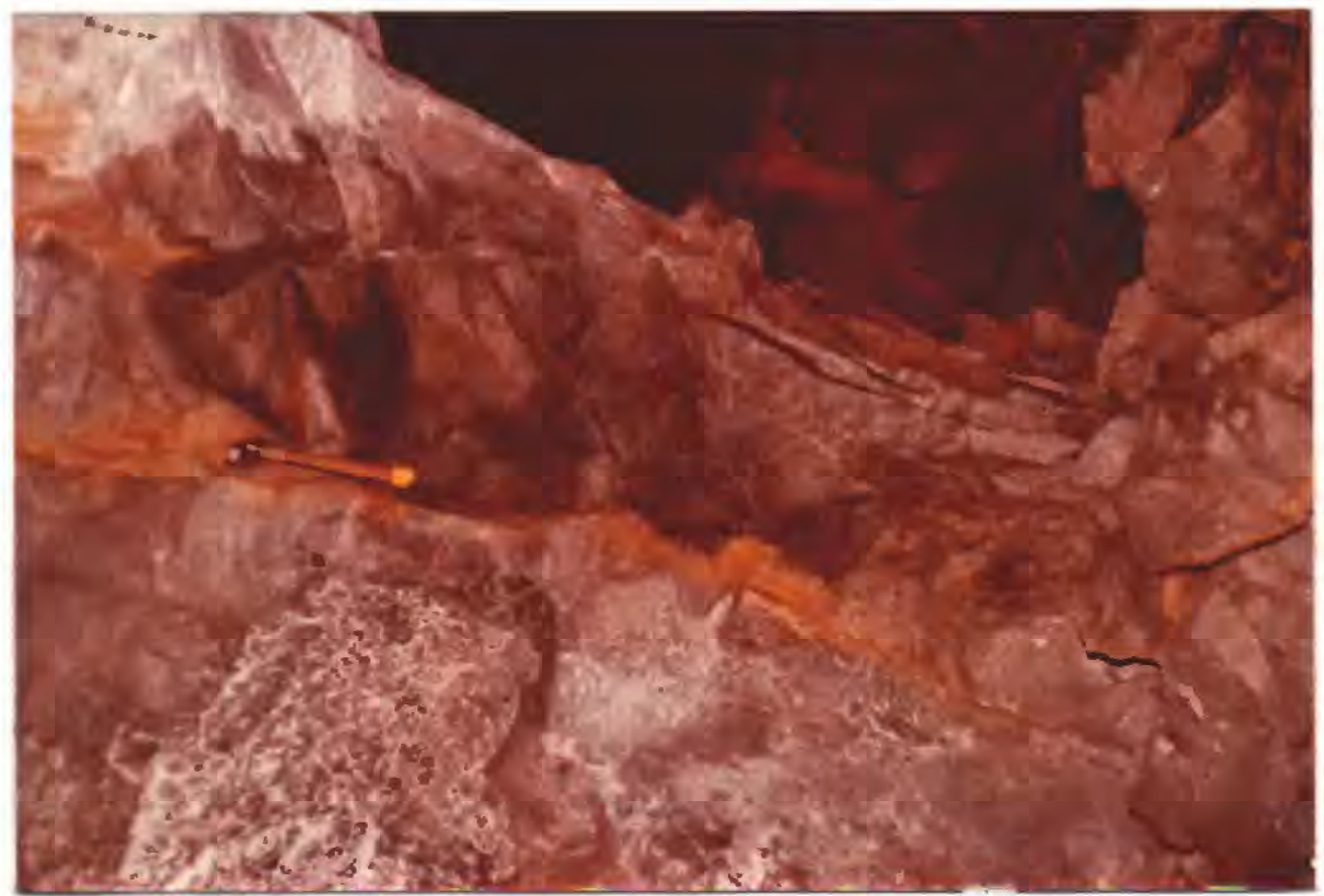

Figure 32, Color photo of limonite stained fracture, annular ring, 365 level, note hammer for scale. Photo by W. L. Chenoweth. 
On the surface, iron staining, bleaching and silicification are common alteration features. Silicification has also affected portions of the $B$ ore body.

Assays of cores from the deep drilling within the pipe show a nearly constant disequalibrium where the chemical uranium is greater than the radiometric equivalent (see Pages A-23 through A-30). One sample of a limestone breccia in Hole P-ll assayed $0.43 \% \mathrm{U}_{3} \mathrm{O}_{8}$ and $0.048 \mathrm{eU}_{3} \mathrm{O}_{8} \cdot$ This same sample was found to contain 0.068 e thorium $230,0.0048$ e radium 226 and 0.00048 e polonium 210 (see Page A-24). This suggests that uranium is still migrating down the pipe structure. Origin of The Pipe

Early reports on the Orphan Lode attributed its origin to a cryptovolcanic structure or diatreme. This was largely due to the fact that Max G. Kofford, chief mine geologist for Golden Crown and Western Gold and Uranium, proposed that theory from the earliest days of the mine. His ideas no doubt influenced Ashwill (1957), Granger and Raup (1962), Magleby (1961) and the AEC (1959a). Kofford considered the diatreme to be Pliocene - Quaternary in age.

Bowles (1965) suggested that the Orphan pipe originated prior to the cutting of the Grand Canyon, as the result of the collapse of the overlying sediments into a solution cavern in the Redwall Limestone. According to this theory, subsidence occurred after the deposition of the Coconino Sandstone, but before its lithification. Recent studies in the Grand Canyon region have demonstrated that the dissolution of the Redwall Limestone began in the 
Mississippian, 300 million years ago (Wenrich, 1985). Upward stoping and breccia pipe formation continued through the Permian, or at least was reactivated then. Observations in the A zone indicate that the Coconino Sandstone was unconsolidated or poorly cemented at the time of the collapse. It is interesting to note that A. R. Still in a 1954 private report to Golden Crown Mining Company, suggested that unconsolidated Coconino sand poured into a cavity in the Hermit Shale that was created by the solution of underlying limestones, during the deposition of the Coconino. I would certainly agree with Still that the collapse of the Coconino Sandstone into the pipe took place soon after, or during its deposition.

Two samples of uraninite ore have been dated using $\mathrm{U}-\mathrm{Pb}$ isotope data. A minimum age of 141 million years for the uranium mineralization at the Orphan Lode has been determined (Gornitz and Kerr, 1970). An ore sample collected by C.G. Bowles of the USGS in 1964 from the 585 level was recently analyzed by the USGS using U-P isotope data. This sample gave a minimum age of 130 million years (K.R. Ludwig, oral communication, 1986). Preliminary $\mathrm{U}-\mathrm{Pb}$ isotope data on samples from other uranium-bearing breccia pipes on the north rim of the Grand Canyon suggest a main period of mineralization of roughly 200 million years (Wenrich, 1985).

Breccia pipes in the Grand Canyon region are known to occur in rocks as young as Triassic. The 200 million year age is in better agreement with the observed break between the Triassic and Jurassic, than the younger Orphan ages (Early Cretaceous). 
Age dating of the samples located during this study may shed new light on the uranium mineralization at the orphan Lode.

In order to determine the possible origin and extent of the Orphan pipe, Hole No. P-13 was drilled from the 550 level. This vertical hole was begun in April 1961 and was completed on May 10, 1962 at a total depth of 1,914 feet, at a reported cost of $\$ 50,000$. Drilling in the supai breccia within the pipe was very slow and difficult due to the unconsolidated and plastic nature of the rock. Voids in the breccia created many problems for the circulation of the drilling mud, and considerable grouting had to be done. At one time, when a fracture was encountered, all of the drilling mud was sucked out of the drill sump, down into the the borehole. While drilling in a limestone breccia, a small pocket of non-flammable gas was encountered which blew the drilling mud out of the borehole.

The author reviewed a copy of the lithologic log of this hole in 1962 at the mine office on the property. This log indicated that the pipe bottomed in the Redwall Limestone, about 300 feet below the normal top of the formation outside of the pipe. Unbrecciated Redwall was encountered at 761 feet, or at the 1311 level of the pipe. Since the pipe extends some 350 feet above the adit level, the pipe containing the Orphan Lode deposit has a minium vertical extent of 1,660 feet.

The top of the Bright Angel Shale was encountered at 1,515 feet and the Tapeats Sandstone was penetrated at $1,854.4$ feet before the drilling ceased at 1,914 feet. A sample of core from the Muav Limestone, which underlies the Redwall (Figure 2), was 
examined by S.R. Austin of the AEC (see Pages A-11 through A-13). This sample showed no indication of any alteration and was typical of outcrops of this unit in this area of the Grand Canyon.

Analysis of samples from the $P$ series of drill holes (Table 3) indicated that a large volume of low-grade material exists between the 500 and 1100 levels of the pipe. Cotter Corporation geologists have estimated that there is a minimum of $9,500,000$ tons of material, averaging 0.021 percent $\mathrm{U}_{3} \mathrm{O}_{8}$, or approximately $3,999,000$ pounds of $\mathrm{U}_{3} \mathrm{O}_{8}$ in this area of the pipe (E.W. Bruner, written communication, 1985).

\section{Summary}

The Orphan Lode Mine occurs in a vertical, nearly circular, collapse-breccia pipe, which penetrates the Coconino Sandstone, Hermit Shale, Supai Group and part of the Redwall Limestone. The diameter of the pipe varies greatly depending on the lithology of the surrounding sediments.

The lithology of the breccia in the pipe, the stratigraphy of the surrounding sediments, and fracturing associated with the collapse have all localized the ore bodies. Uraninite is the principal uranium mineral. Copper minerals appear to be zoned in relationship to high grade uranium deposits on the perimeter of the pipe. Pyrite and calcite are common gangue minerals. Besides uranium and copper, the ores at the Orphan Lode contain varying 
percentages of silver, nickel, cobalt, lead, zinc, and vanadium. An envelope of calcified rock surrounds the pipe in the lower levels.

Drilling has confirmed that the breccia pipe bottoms in the middle part of the Redwall Limestone, and has a minimum vertical extent of 1,660 feet. 


\section{REFERENCES CITED}

Albrethsen, Holger, Jr. and McGinley, F. A., 1982, Summary history of domestic procurement under U.S. Atomic Energy Commission contracts, final report: U.S. Department of Energy, Open File Report GJBX-220(82), 162 p.

Ashwill, W. R., 1957, The Orphan uranium mine Grand Canyon, Arizona: U.S. Atomic Energy Commission, Open File Report RME-2082, $19 \mathrm{p}$.

Billingsley, G. H., 1974, Mining in Grand Canyon, in Geology of the Grand Canyon: Museum of Northern Arizona, Grand Canyon Natural History Association, p. 170-178.

Bowles, G. C., 1965, Uranium-bearing pipe formed by solution and collapse of limestone, in Geological Survey Research, 1965: U.S. Geological Survey Professional Paper 525-A, p. Al2.

Brown, J. F., 1955, Certification of the Orphan Lode claim, Arizona District, Coconino County, Arizona (Application No. 705): U.S. Atomic Energy Commission Report C-731, unpublished, $6 \mathrm{p}$.

Brundy, C. M., 1977, Orphan with a Midas touch: Denver Post, Empire Magazine, Nov. 27, 1977, p. 12-17.

Dodge, Matt, and McKlveen, J. W., 1970, Hogan's Orphan mine: True West Magazine, Dec. 1970, p. 6-10,40, 42.

Engineering and Mining Journal, 1968, Arizona: Engineering and Mining Journal, Vol. 169, No. 1, p. 122 .

Gornitz, Vivien, and Kerr, P. F., 1970, Uranium mineralization and alteration, Orphan mine, Grand Canyon, Arizona: Economic Geology, Vol. 65, p. 751-768.

Granger, H. C., 1951, Preliminary summary of reconnaissance for uranium in Arizona: U.S. Geological Survey Trace Elements Memorandum Report 304 , 11 p.

Granger H. C., and Raup, R. B., 1962, Reconnaissance study of uranium deposits in Arizona: U.S. Geological Survey Bulletin 1147-A, p. Al-A54. 
Grand Junction office AEC and U.S. Geological Survey, 1970, Preliminary reconnaissance for uranium in Coconino County, Arizona, 1951 to 1955: U.S. Atomic Energy Commission Report RME-155, U.S. Government Printing Office, $119 \mathrm{p}$.

Kofford, M. E., 1969, The Orphan mine: Four Corners Geological Society Guidebook, p. 190-194.

Lynch, J. T., and Viklund, H. I., 1956, Preliminary leaching and ion exchange studies of a sample of Western Gold and Uranium Company ore: U.S. Atomic Energy Commission Topical Report WIN-8, $16 \mathrm{p}$.

Magleby, D. N., 196l, Orphan Lode uranium mine, Grand Canyon, Arizona: U.S. Atomic Energy Commission, Open File Report TM-134, $18 \mathrm{p}$.

Pay Dirt, 1969, Orphan Mine suspends uranium ore production: Pay Dirt, April 28, 1968, p. 26.

McKee, E. D., 1982, The Supai Group of Grand Canyon: U.S. Geological Professional Paper 1173, 504 p.

Mining World, 1959, How Western Gold mines uranium in Grand Canyon: Mining World, Vol. 1, No. l, p. 32-35.

Runke, S.M., 1964, The Tuba City uranium milling operations: El Paso National Gas Company, Paper presented at the National Western Mining Congress, Denver, Colorado, February 7, $1986,20 \mathrm{p}$.

Scarborough, R. B., 1981, Radioactive occurrences and uranium production in Arizona: U.S. Department of Energy, Open File Report GJBX-143(81) 311 p., 21 illus.

U.S. Atomic Energy Commission, 1959a, Orphan Lode, in Mine operation data report: U.S. Atomic Energy Commission, Open File Report AEC-PED-1, p. 324.

U.S. Atomic Energy Commission, 1959b, Orphan Lode Mine (Grand Canyon) in Guidebook to uranium deposits of western United States: U.S. Atomic Energy Commission, Open File Report RME-141, p. 3-44-3-47.

Wenrich, K. J., 1985, Mineralization of breccia pipes in northern Arizona: Economic Geology Vol. 80, p. 1722-1735. 
74

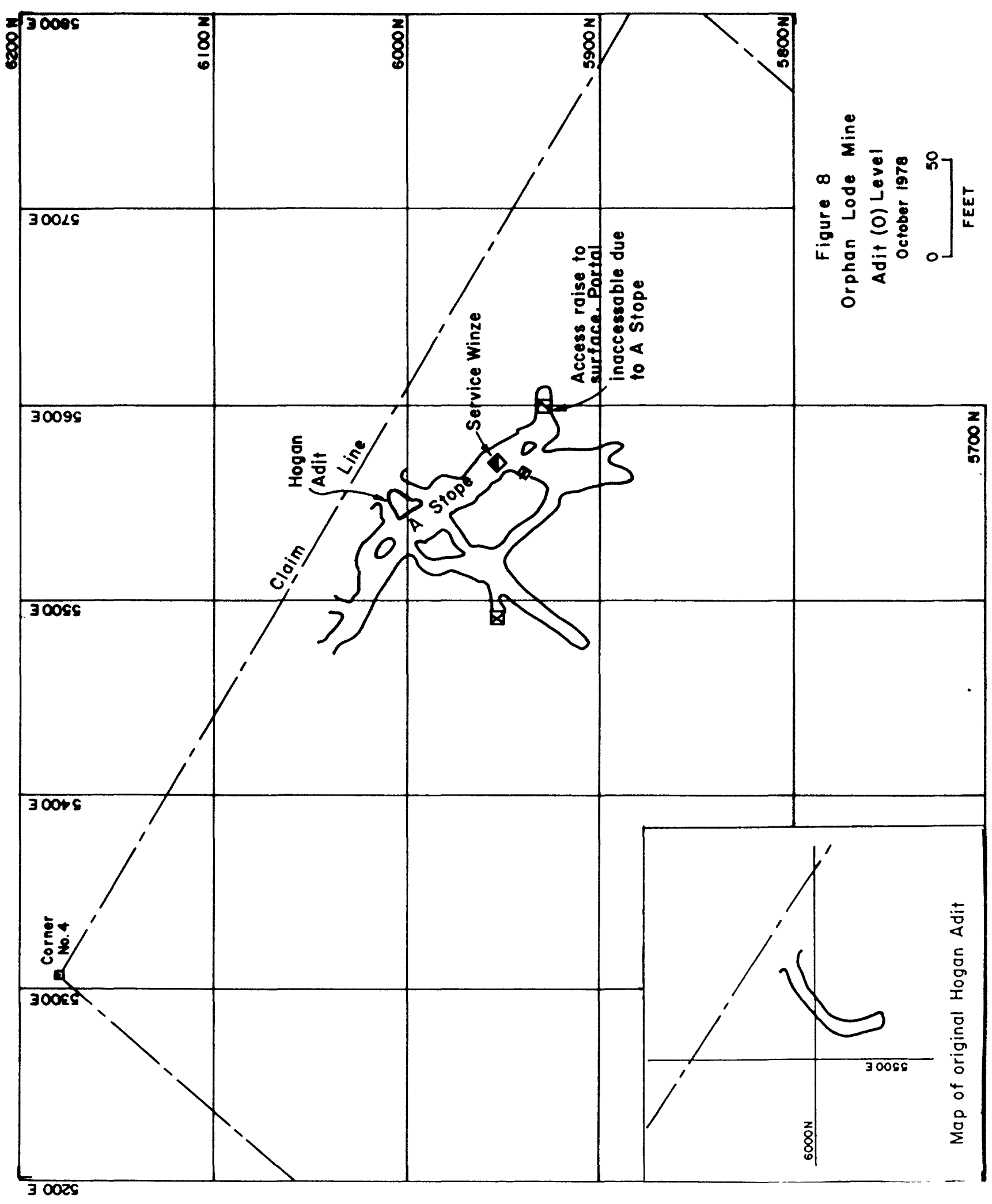




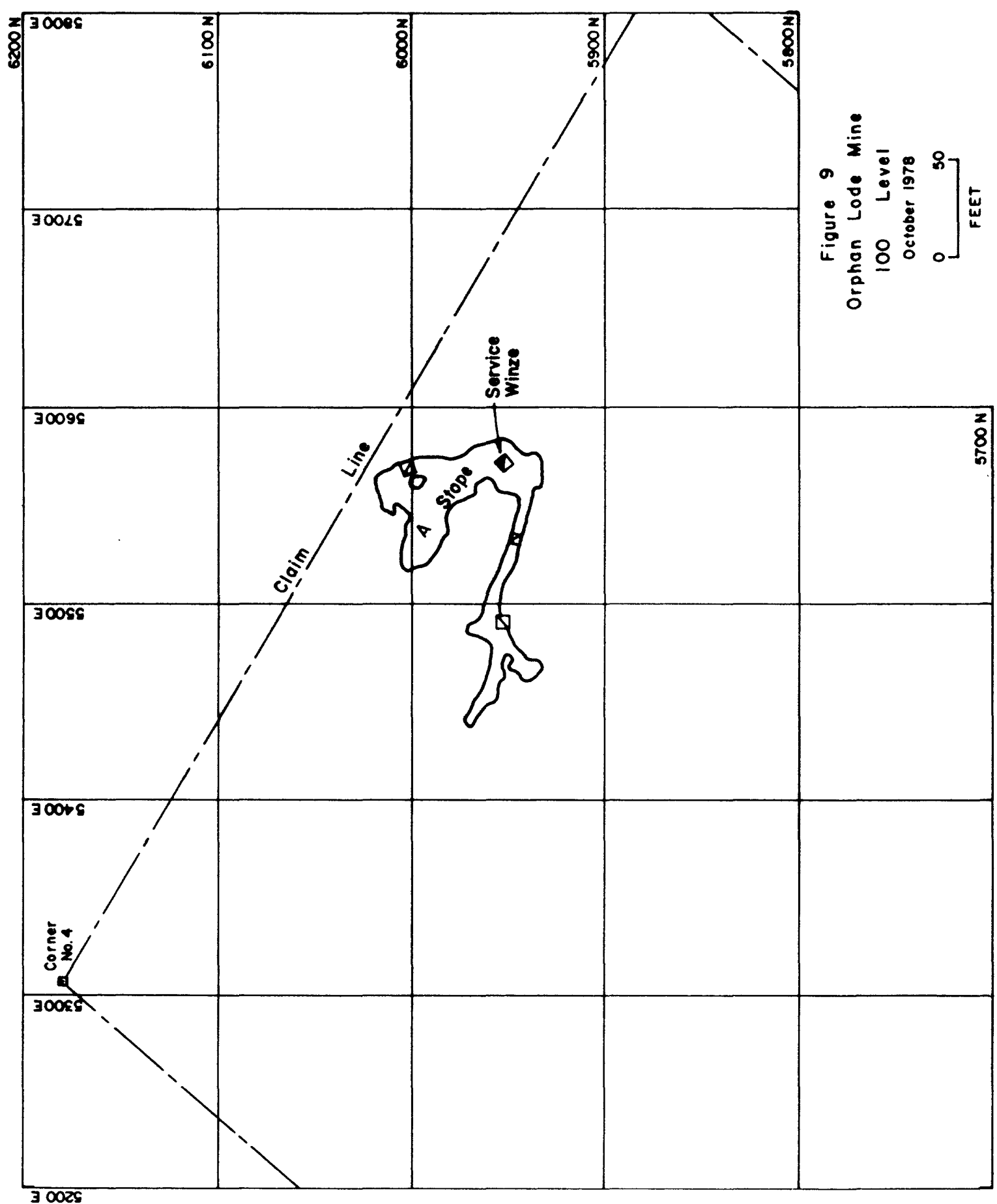




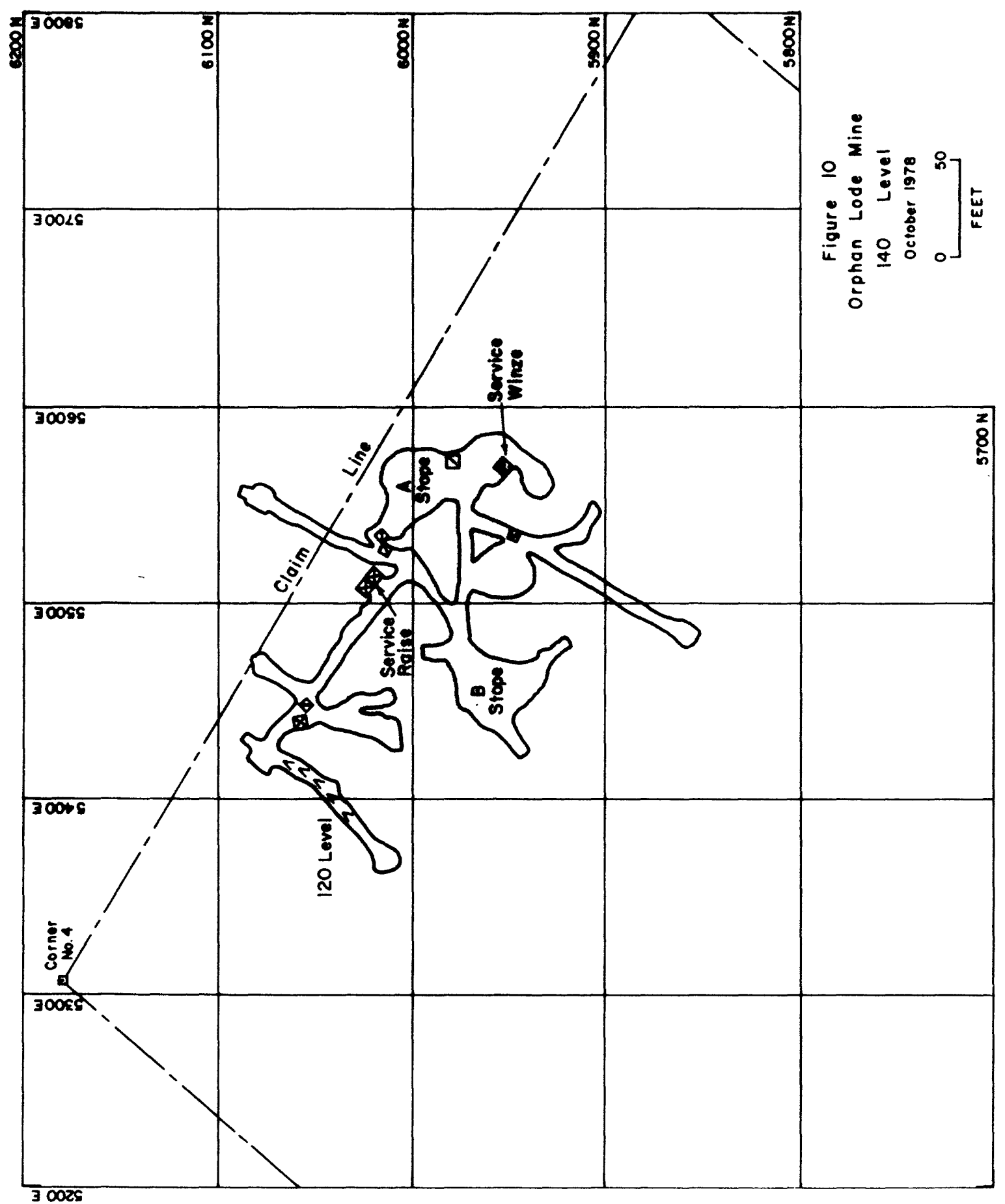




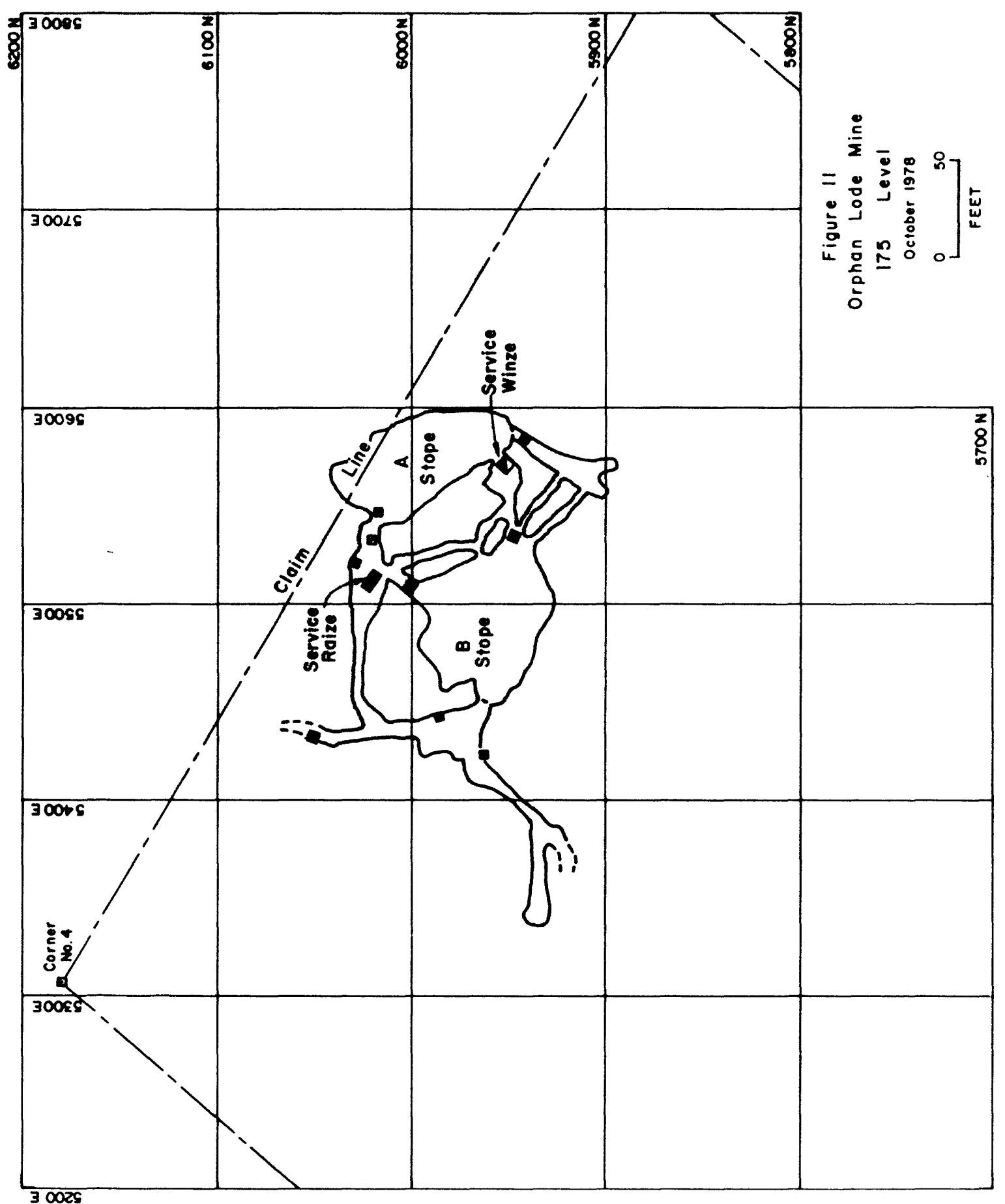




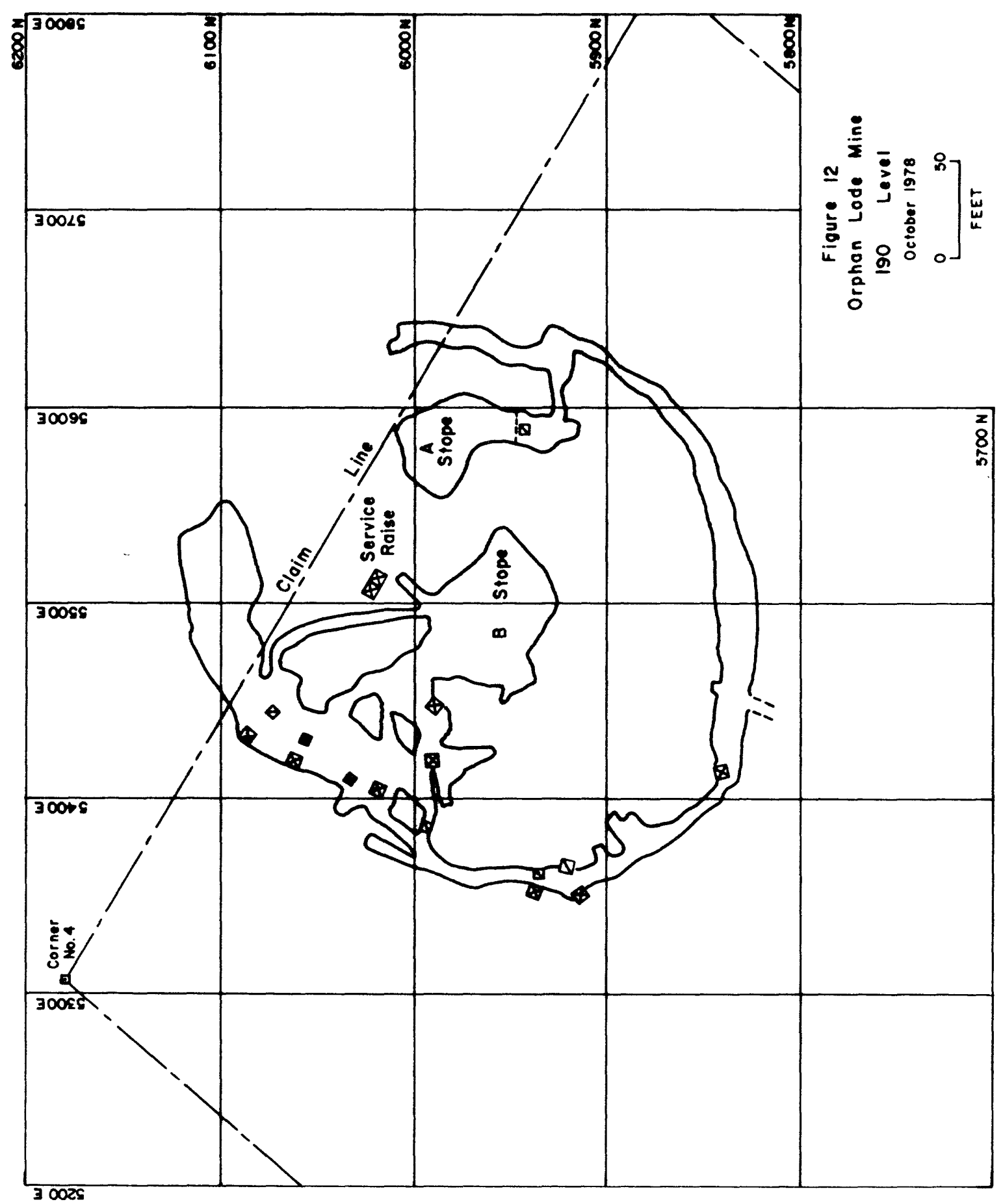




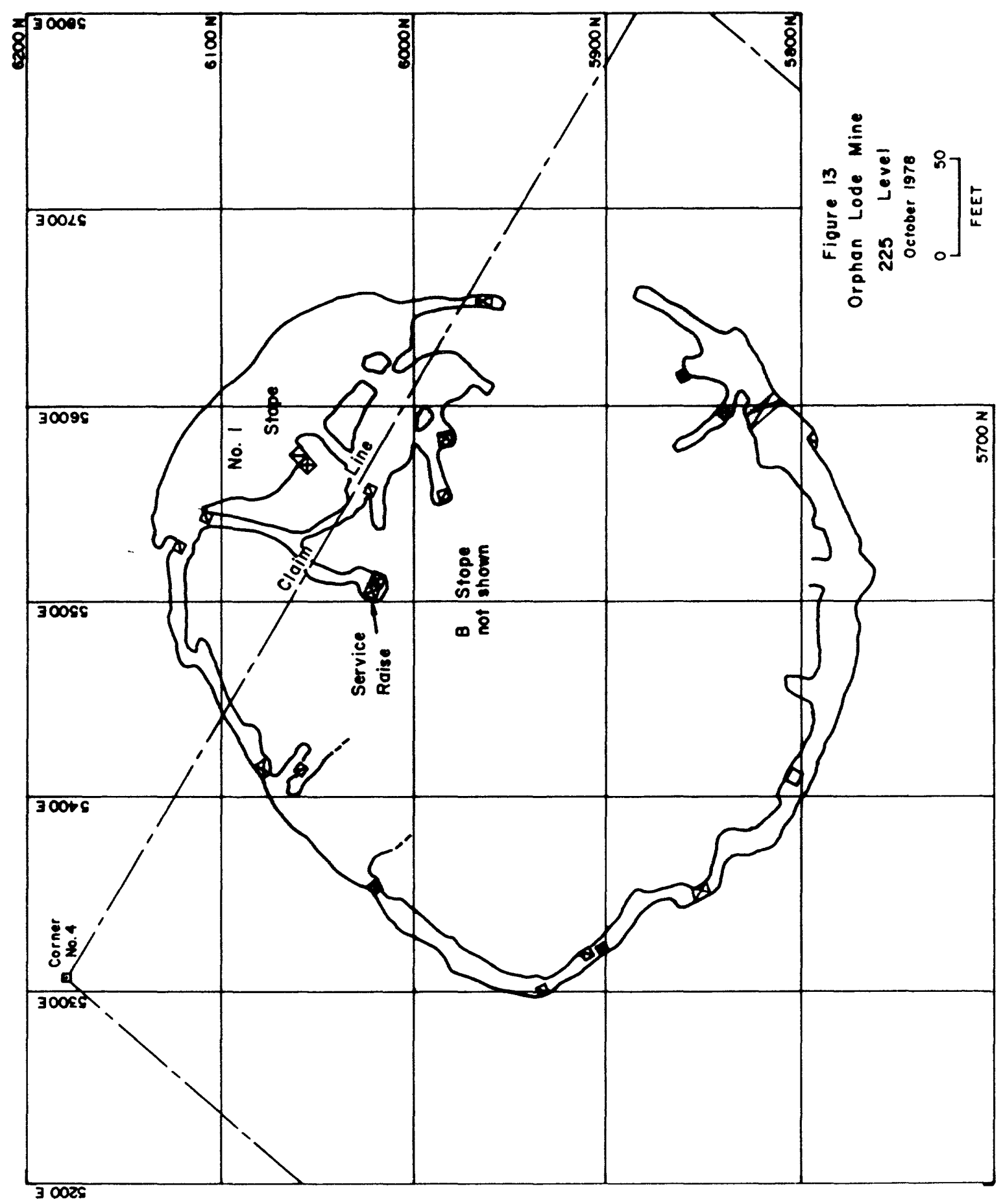




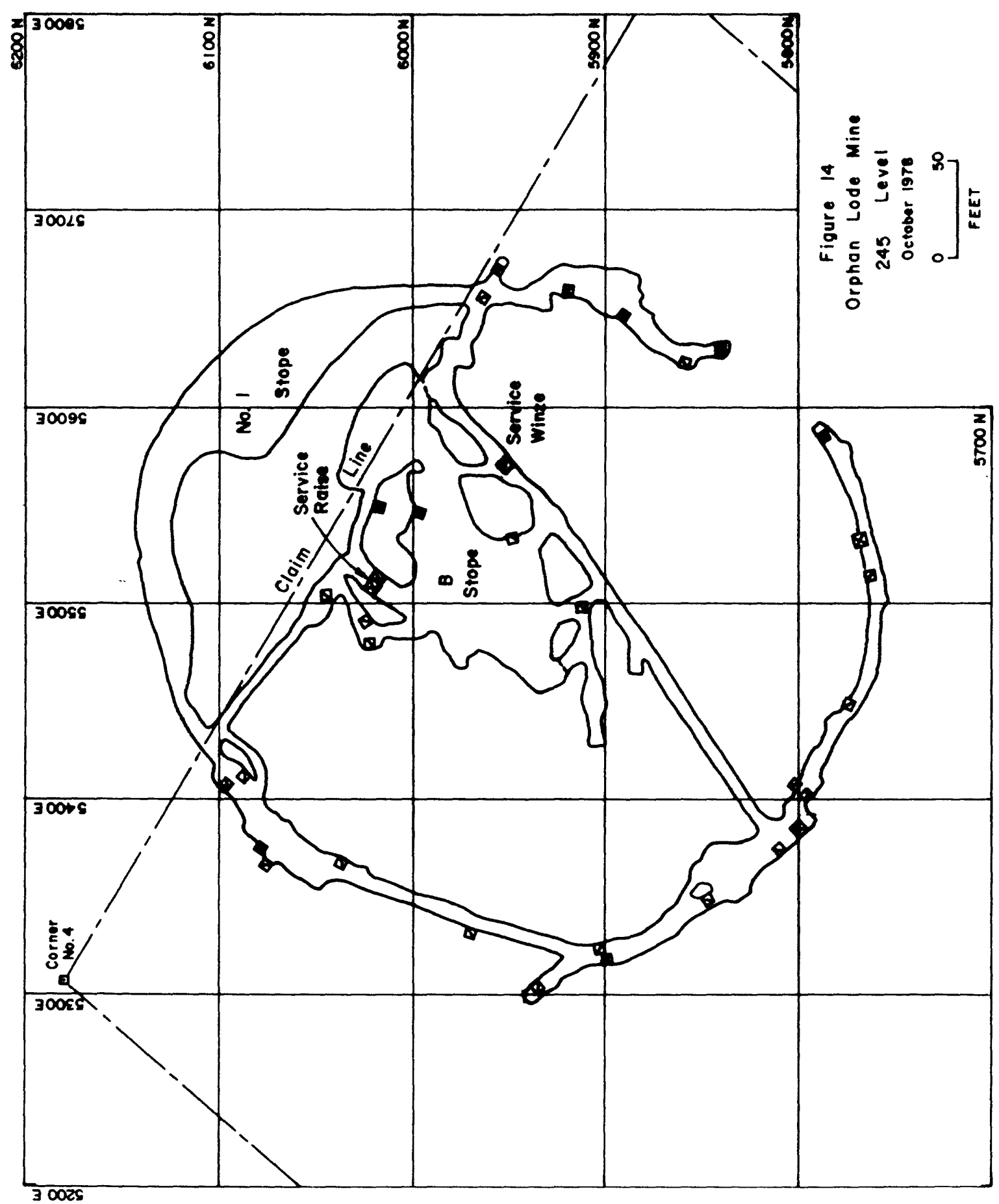


81

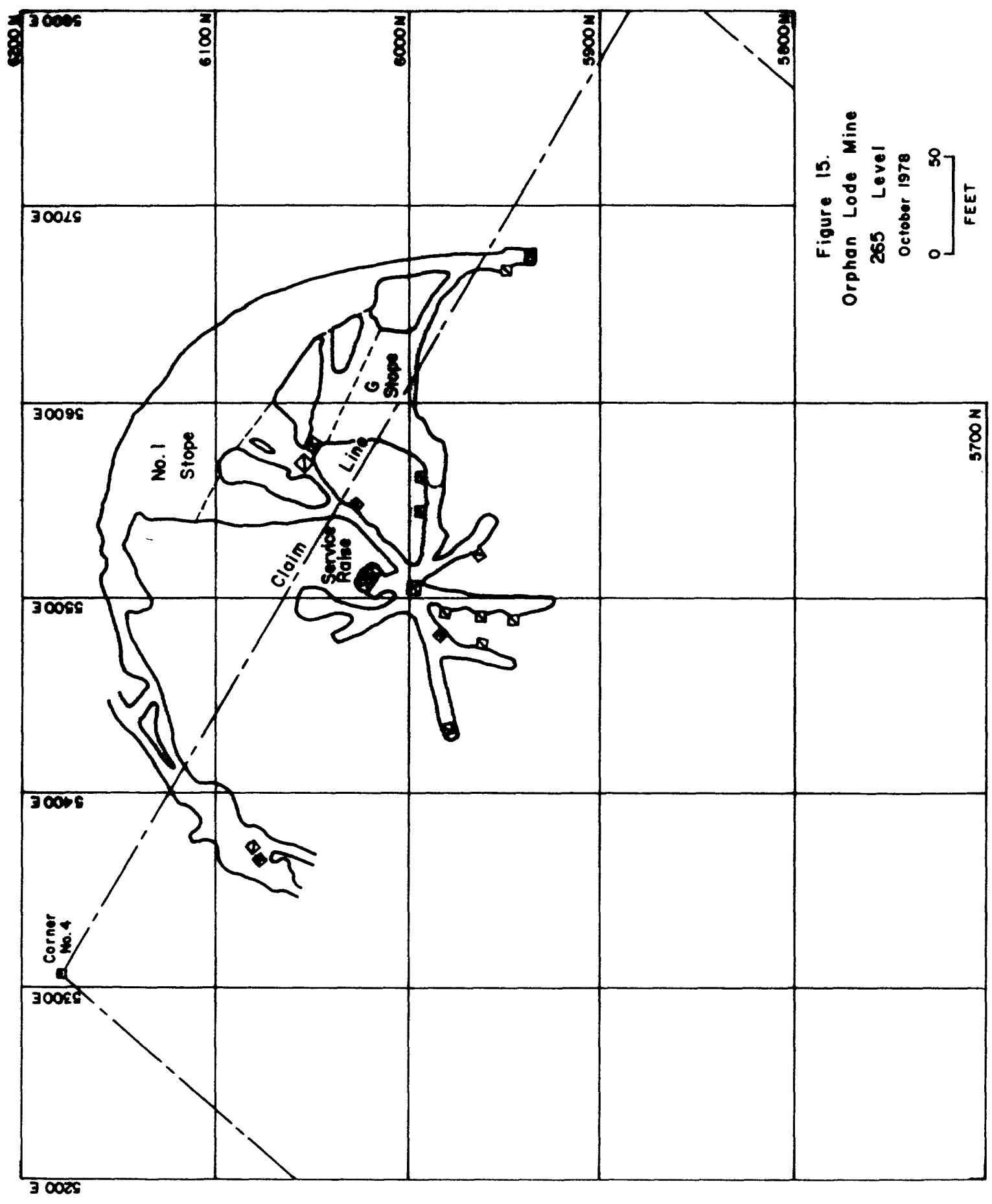




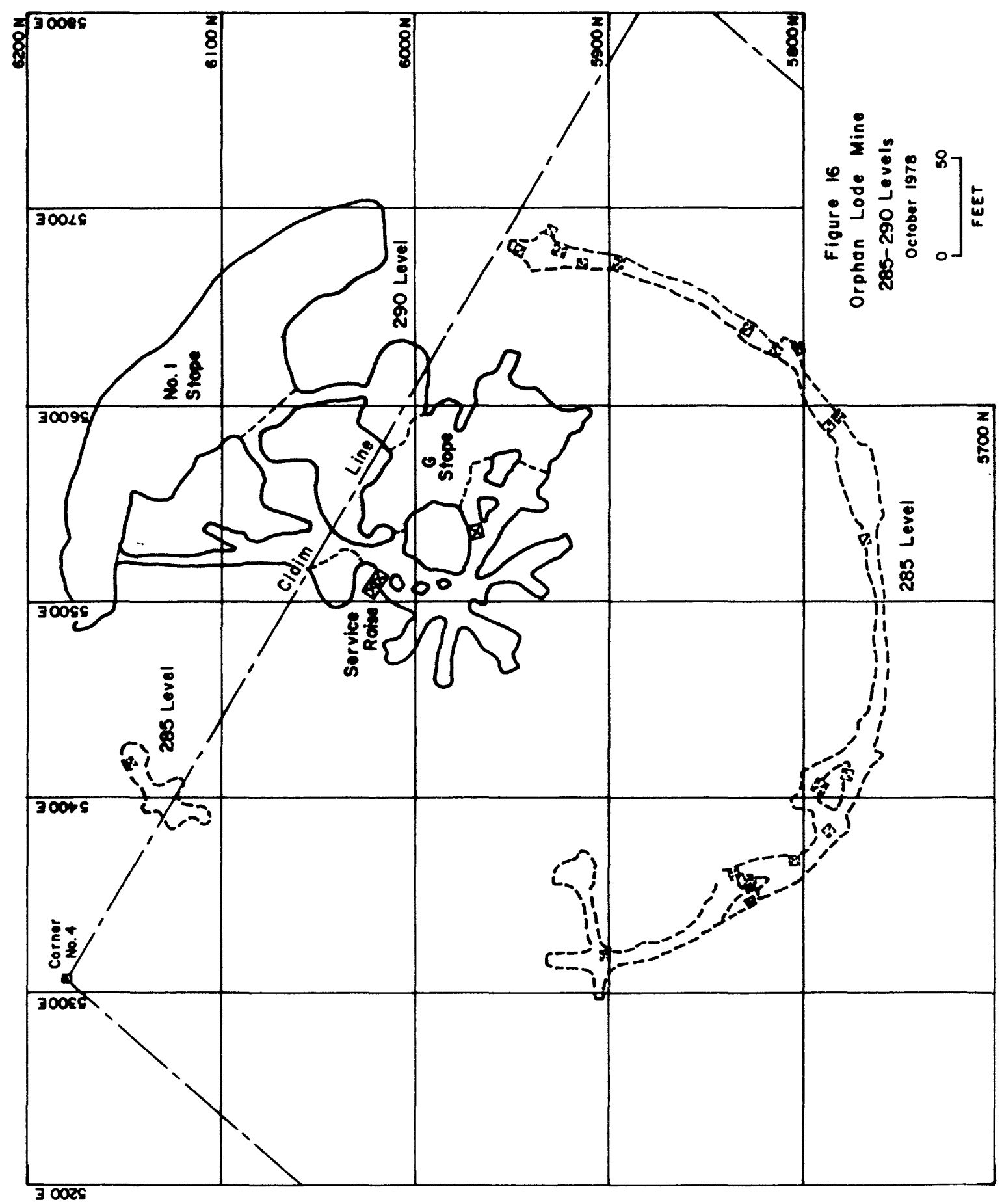




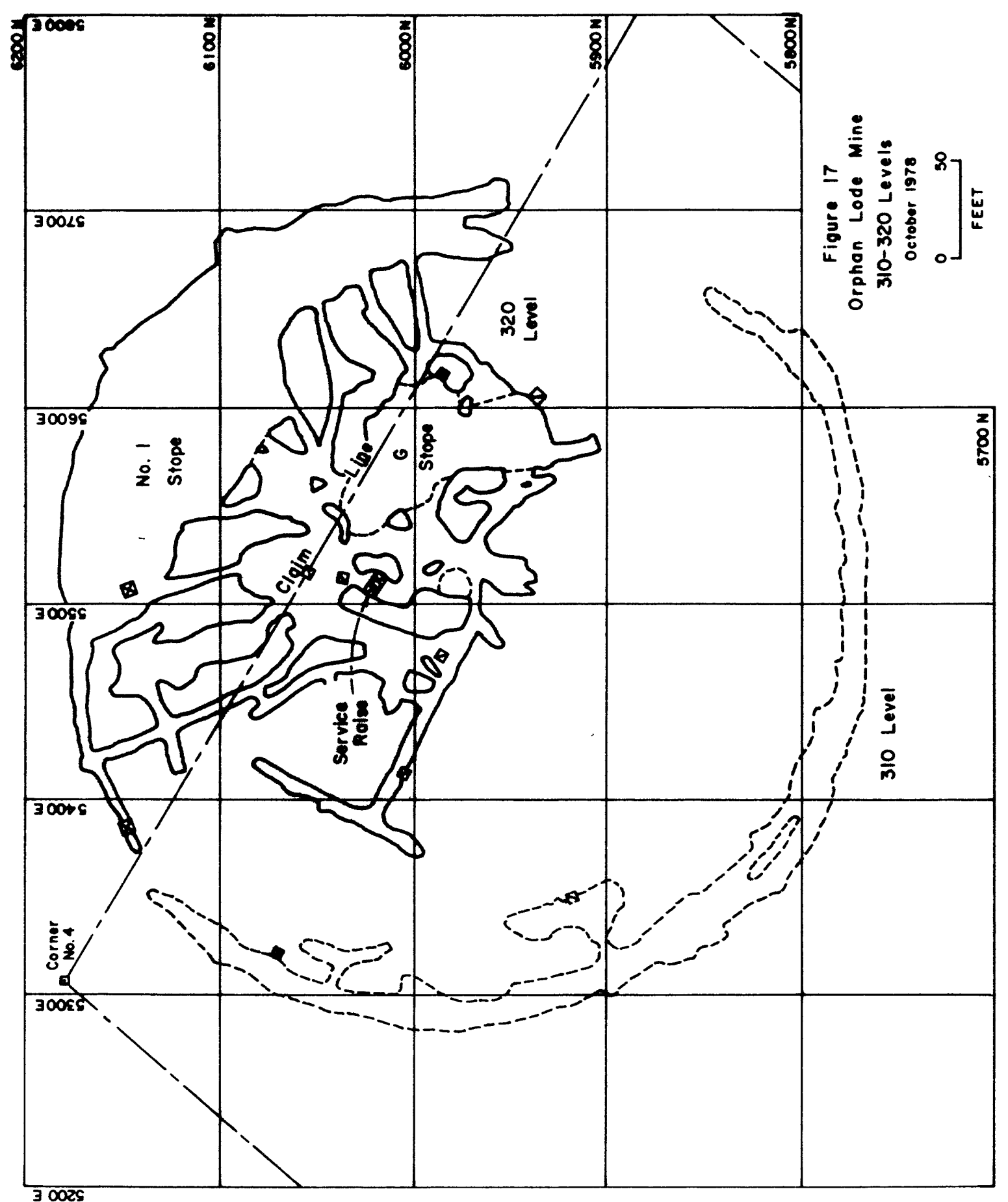




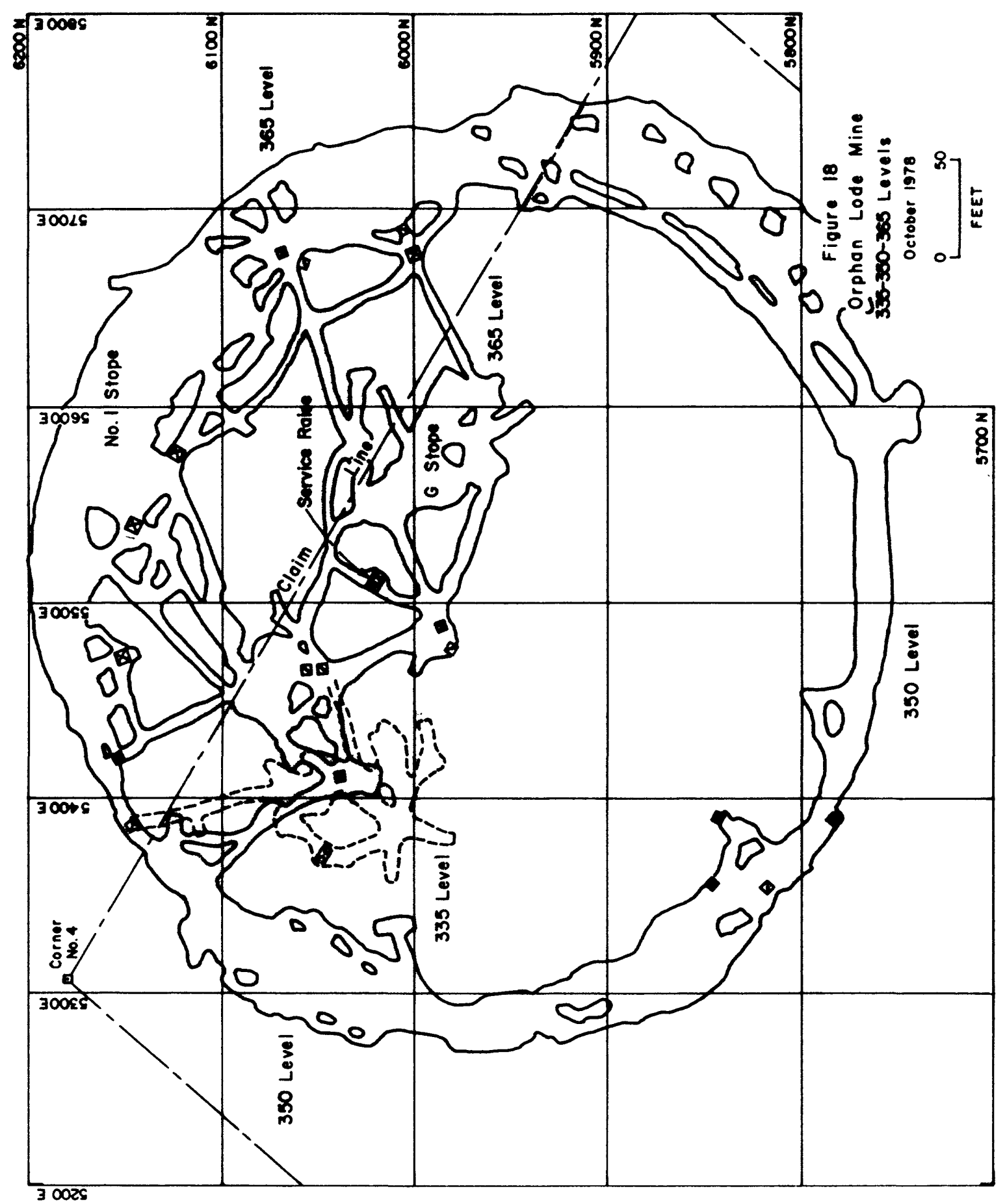




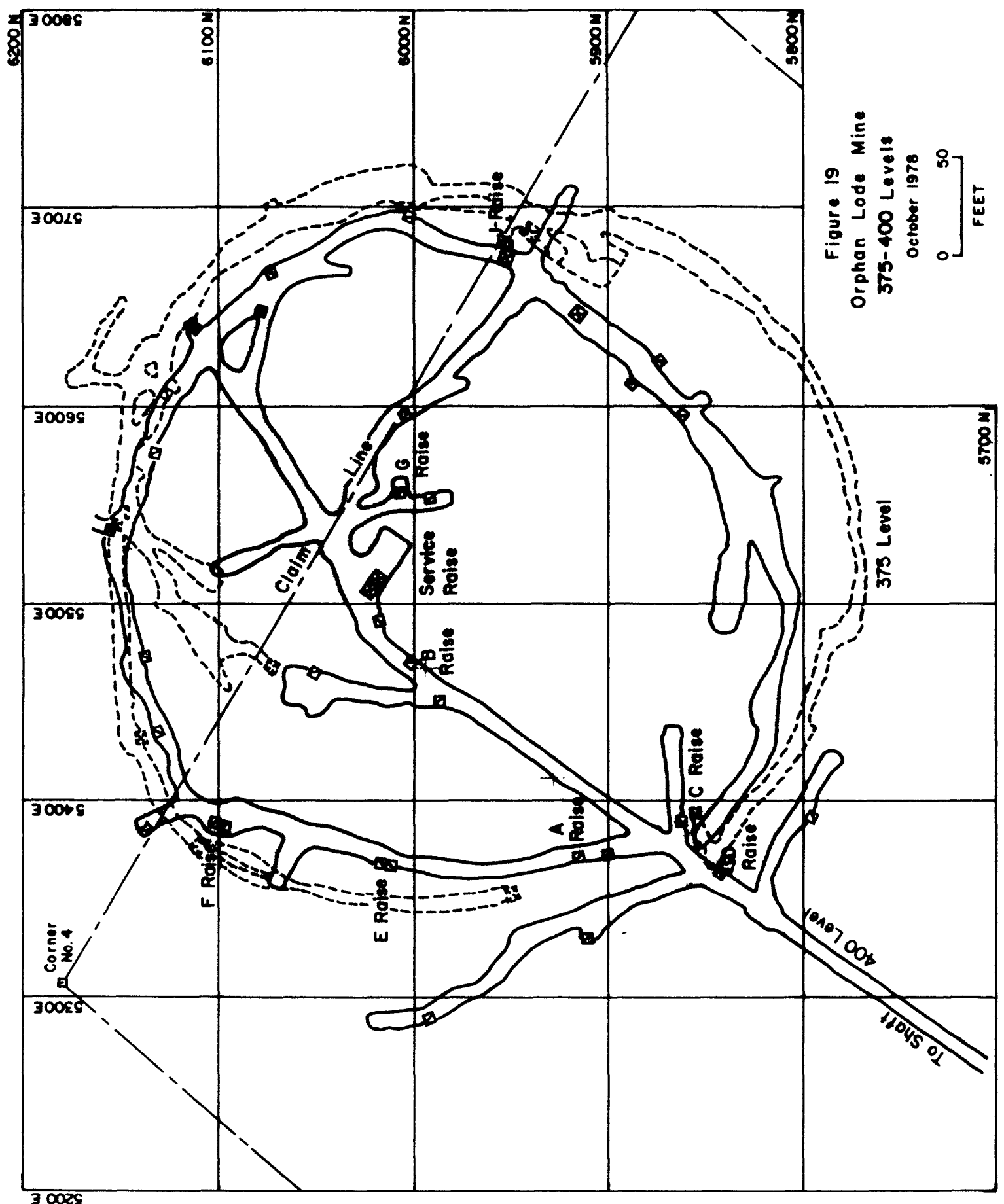




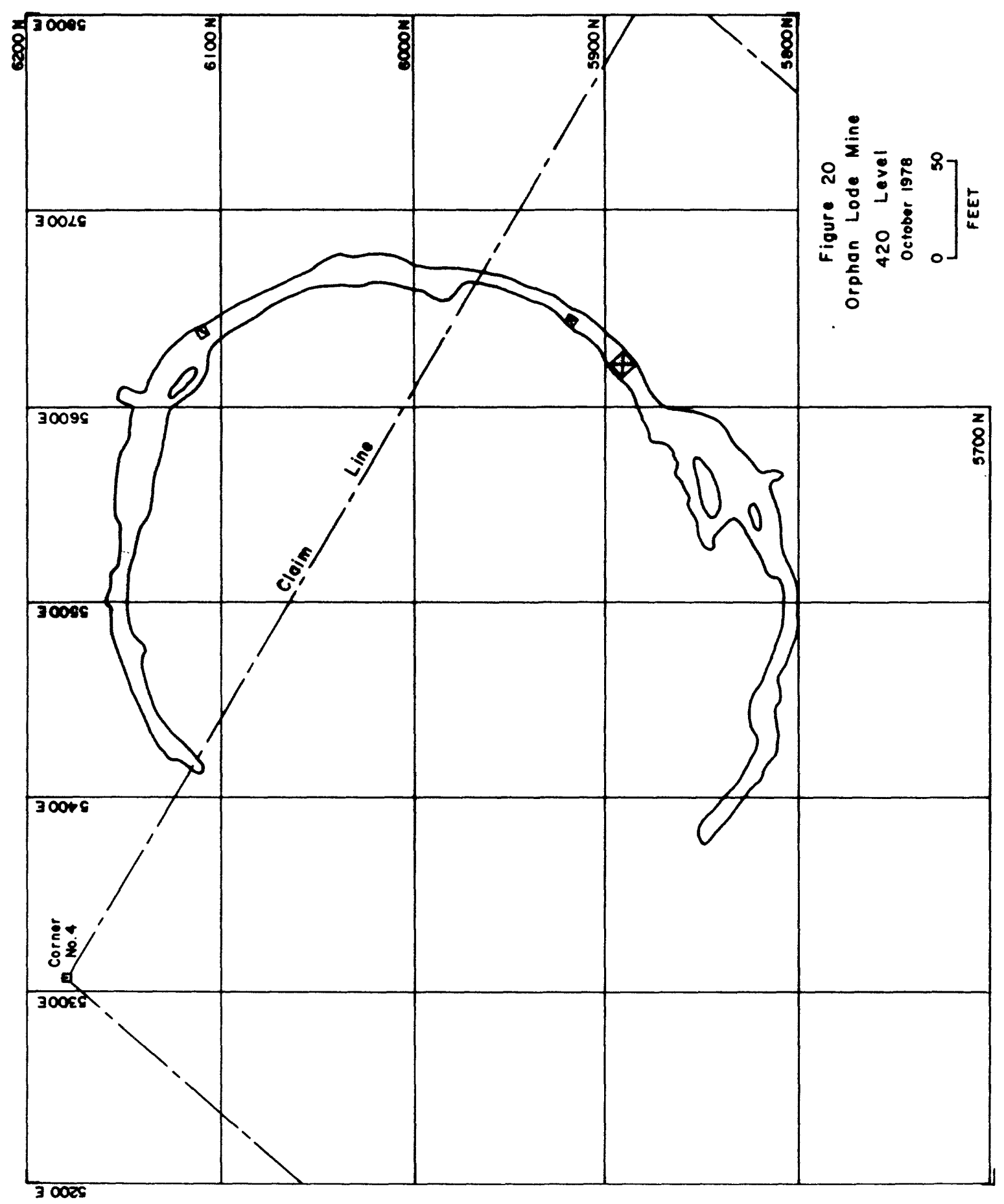




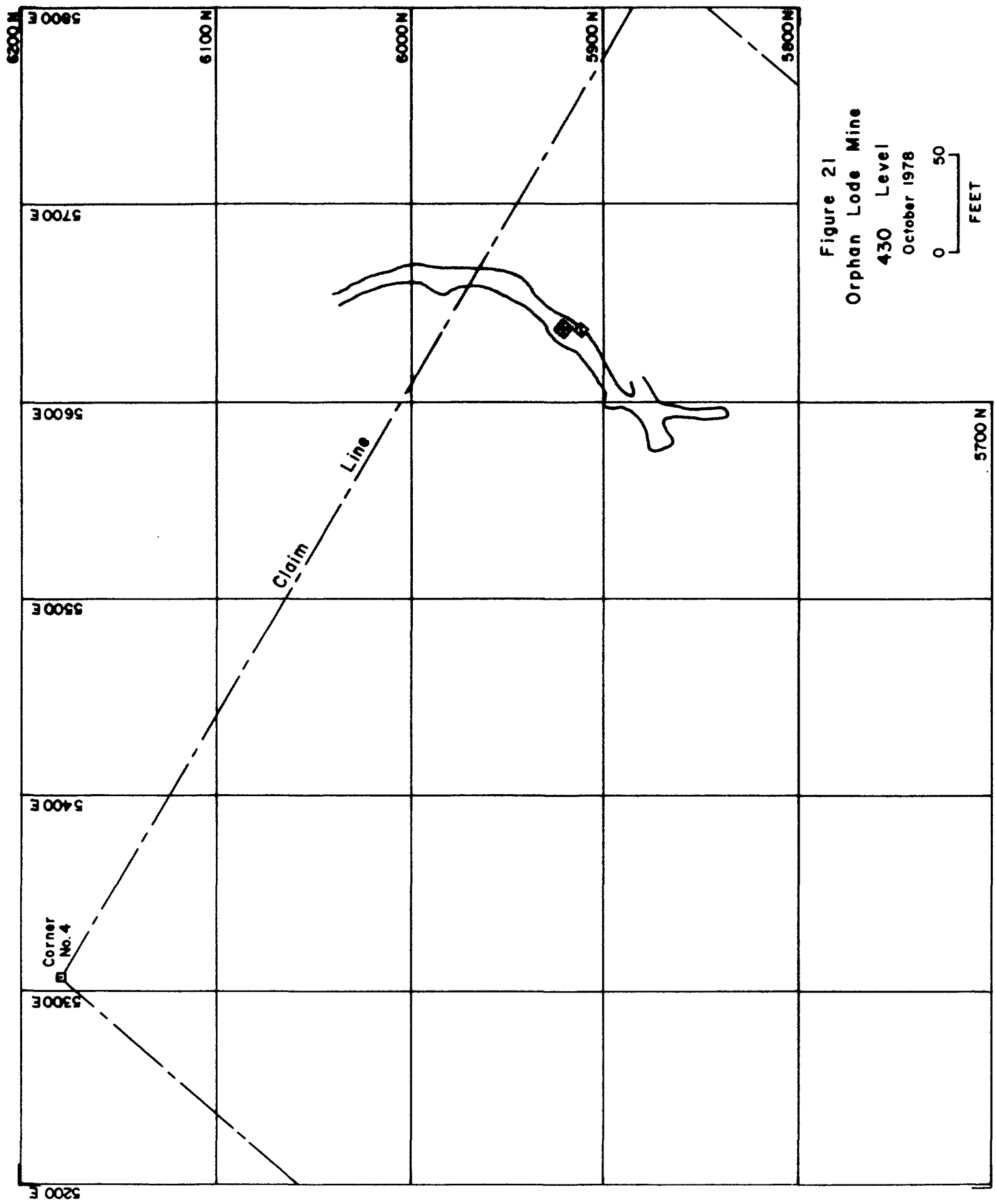




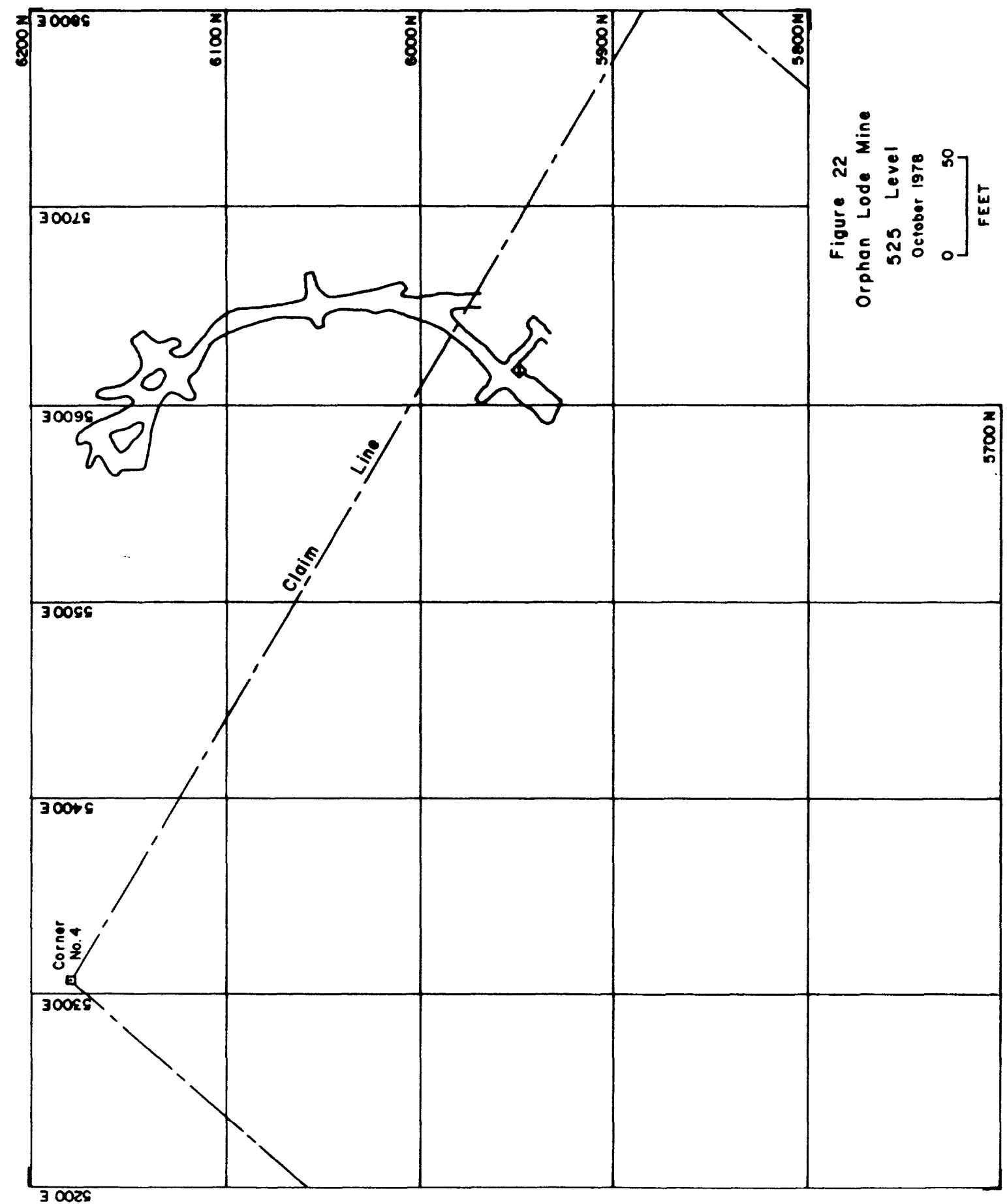




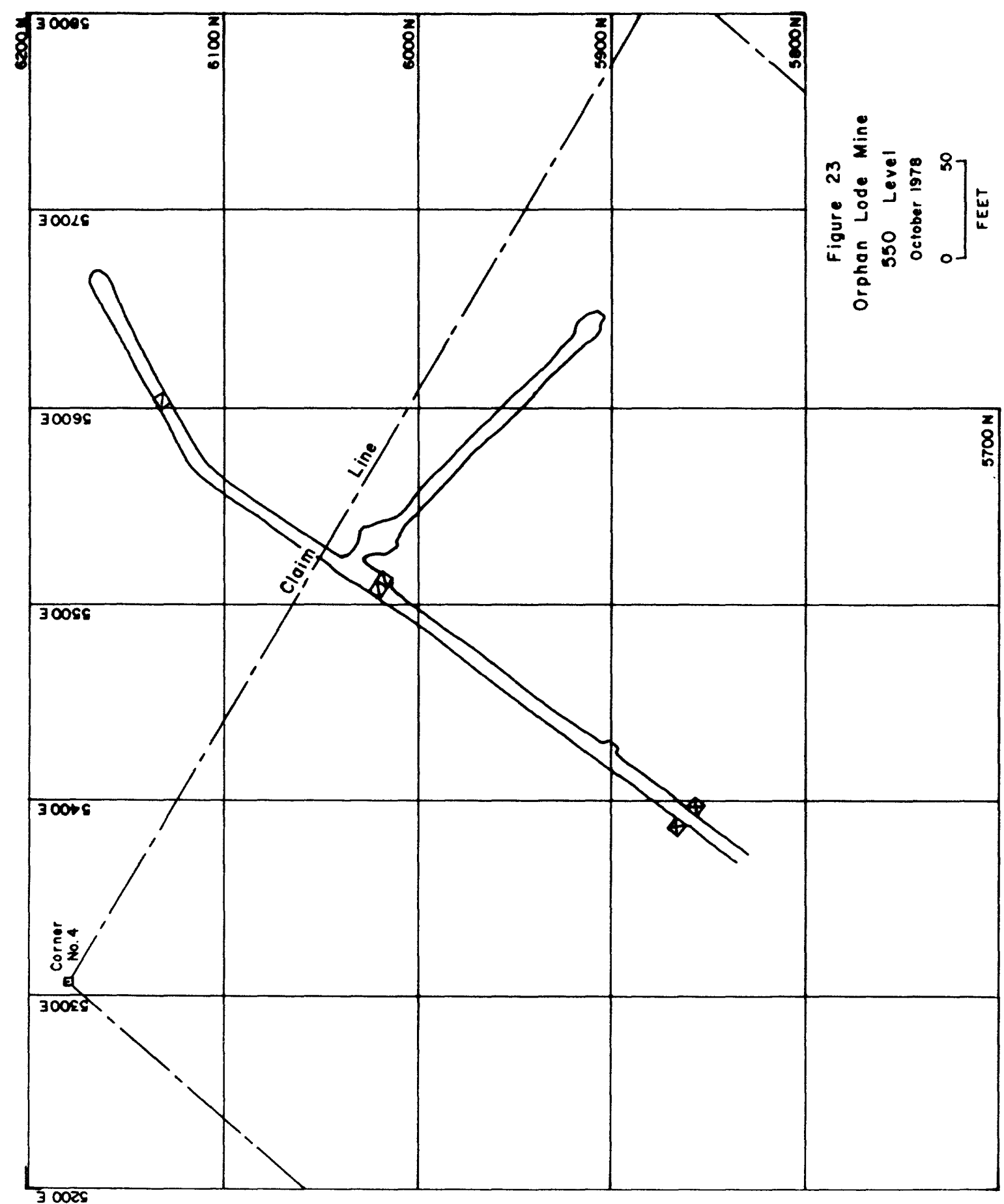


90

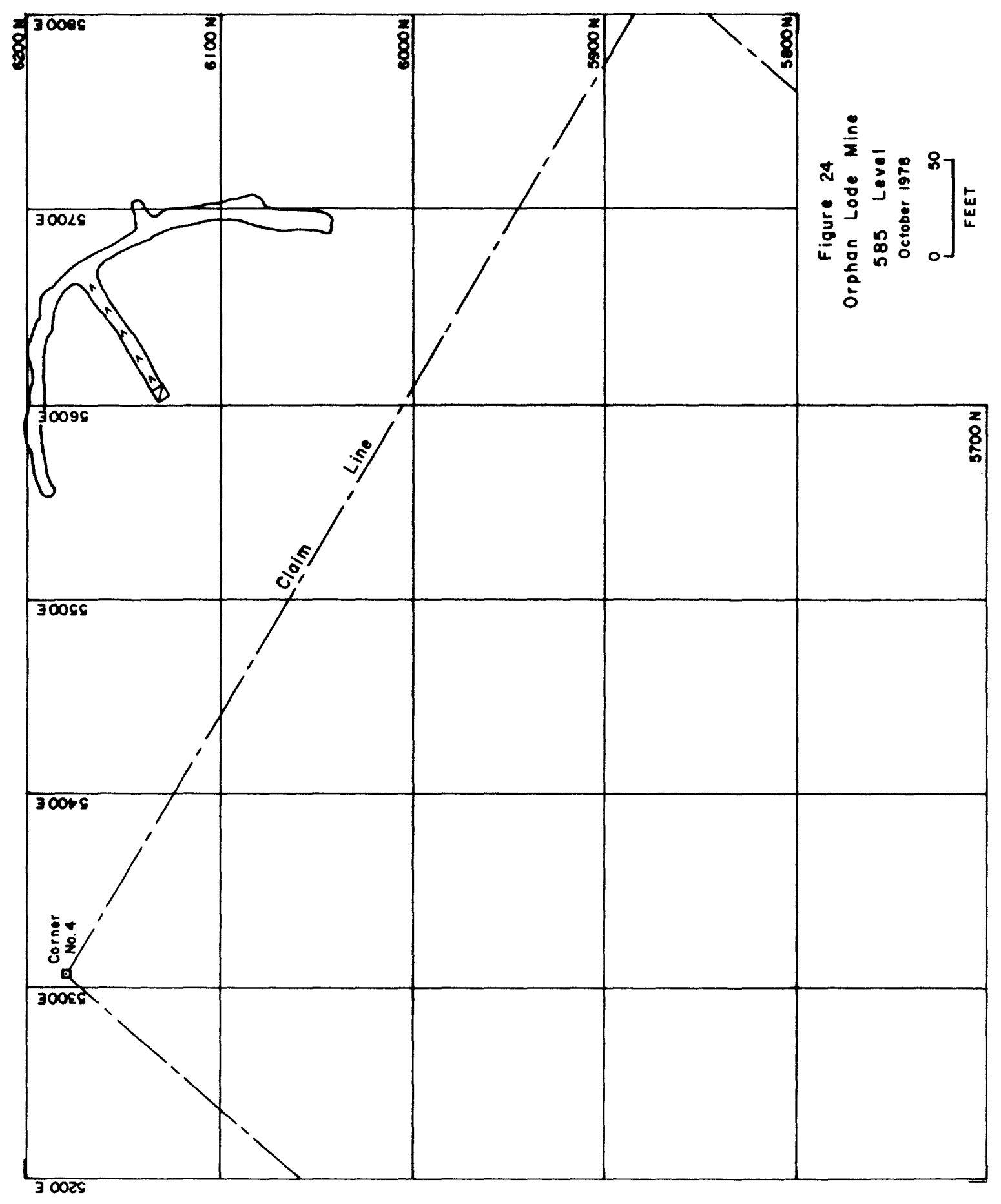




\section{APPENDIX}

\section{Page}

Chronology......................... A-1

Plat of Orphan Claim.................. A-5

Western Gold \& Uranium, Inc. Report......... A-6

Photo of Collapsed Ore Bin............... A-7

Petrographic Reports................... A-8

Analytical Data...................... A-19

Simple Location Maps................... A-31 


\section{CHRONOLOGY}

Significant Events In The History of The Orphan Lode Mine

1893 February 8, Orphan claim staked by Daniel L. Hogan and Henry Ward.

1905 January 18-20, Claim surveyed; Mineral Survey No. 2004.

1906 March 23,

Claim patented; Patent No. 43506.

1908 January 11,

Grand Canyon National Monument established.

1946 August 1 ,

Claim sold by Daniel L. Hogan to Mrs. Bertha Madeleine Jacobs.

1951 April 22,

Uranium minerals in old workings confirmed by USGS.

1953 September 29, Mineral rights to claim leased by Golden Crown Mining Co.

1955 October,

Diamond drilling began in Hogan's old adit.

December 14,

Golden Crown announced a major uranium deposit had been discovered in a pipe structure.

1956 March,

A three tower aerial tram was constructed from rim to mine.

April 25,

Initial shipment of ore made from orphan Lode Mine.

May,

Original aerial tram removed, a new Riblet tram erected.

August,

Sustained production began via aerial tram.

1957 March,

Exploration winze from adit level reached a depth of 175 feet ( 175 level).

Exploration drilling from 100 and 175 levels.

July,

Summer ,

Western Gold and Uranium, Inc. acquired full control of Golden Crown Mining Co.

Exploration winze deepened to the 245 level.

1958 May,

Sinking of a $2 \frac{1}{2}$ compartment, vertical shaft on the rim commenced. 
Page 2,

\section{CHRONOLOGY}

Summer,

November 24 ,

Fall,

\section{January,}

March,

Summer,

October,

1960 November,

1961 February,

September 6 ,
Ten holes (G series) drilled into pipe from stations in National Park. A large orebody, off the claim, in the National Park was located.

Atomic Energy Commission announced I imitations on 1962-1966 purchase program. Ore Western Gold had located in the Park was not eligible.

$\mathrm{High}$ lime ore (greater than $68 \mathrm{CaCO}_{3}$ ) becoming a problem at Tuba City. Western Gold sought other markets where ore would not be penalized for high lime.

Shaft completed to a depth of 1,590 feet. A station was cut at 1,502 feet.

A crosscut from the shaft station to 400 level of the pipe was started. The crosscut was completed to the end line of the claim in August.

Development raises driven from the 400 level to 245 level in preparation for all production to be hoisted to the surface via the new shaft.

With the mining expanding, Western Gold established a mobile home park, known as Western Village, for its employees outside the Park adjacent to U. S. Highway 180 .

First production via the new shaft. Orphan Lode now had the production capability of 8,000 tons per month over the 1,000 tons per month via the aerial tram.

Sinking of an exploration winze from the 400 level to the 550 level was started.

Winze completed to 550 level and a drill station for the $P$ series of holes was established.

Lee Ackerman became president of Western Gold through a stock exchange. Name changed to Western Equities, Inc. in November. 
Page 3

CHRONOLOGY

December 22,

1962 January,

May,

May 28,

July,

September 10 ,

November 20 ,

December,

1963 April,

Fall,

1966 Spring,

August 25,
The ore bin on the shaft headframe

collapsed sending ore down the shaft. The mine was closed for repairs.

Shipments to Tuba City ceased when the surface stockpile at Orphan Lode was depleted.

Tuba City mill closed for lack of ore.

Public Law 87-457 signed by President Kennedy. Western Gold could mine ore in the Park, by giving Federal Government title to Orphan claim in 1987.

Rare Metals Corporation of America merged into El Paso Natural Gas Company.

Effective date of a new contract between $A E C$ and E1 Paso which was signed November 19, 1962. AEC to purchase uranium concentrates produced from Orphan Lode ore through December 31, 1966.

Mining resumed at Orphan Lode. Development work to mine ore in National Park commenced. Ore was stockpiled at the Tuba City mill.

Modifications began at the Tuba City mill. A carbonate leaching circuit and sulfide flotation cell were installed to treat high lime ores and recover copper.

Tuba City mill began processing Orphan Lode ore.

A decline from the 550 level to the 585 level was driven to explore ore in the Park. This was the deepest level of the mine.

Western Equities was sold to Geo Space Corporation which merged into Westec Corporation.

Westec's stock suspended from trading on the American Stock Exchange. Company declared bankruptcy, and the Orphan Lode closed. 
Page 4

\section{CHRONOLOGY}

September,

Tuba City mill of El Paso Natural Gas Company closed for lack of ore.

1967 August 31,

Westec asked permission from the U. S. District Court to sell Orphan claim and Western Village to the Cotter Corporation.

September 27, Shipments of Orphan Lode ore, via the Santa Fe Railroad, began to Cotter's mill at Canon City, Colorado. The mill also recovered copper from sulfide minerals in the ore.

1969 April 25,

Orphan Lode Mine closed due to high freight charges to Canon City.

1981 February 18, Western Village site and the Orphan claim were purchased by John R. Siebold and Elling Halvorson. Western Village had become a prime area for real estate development. 

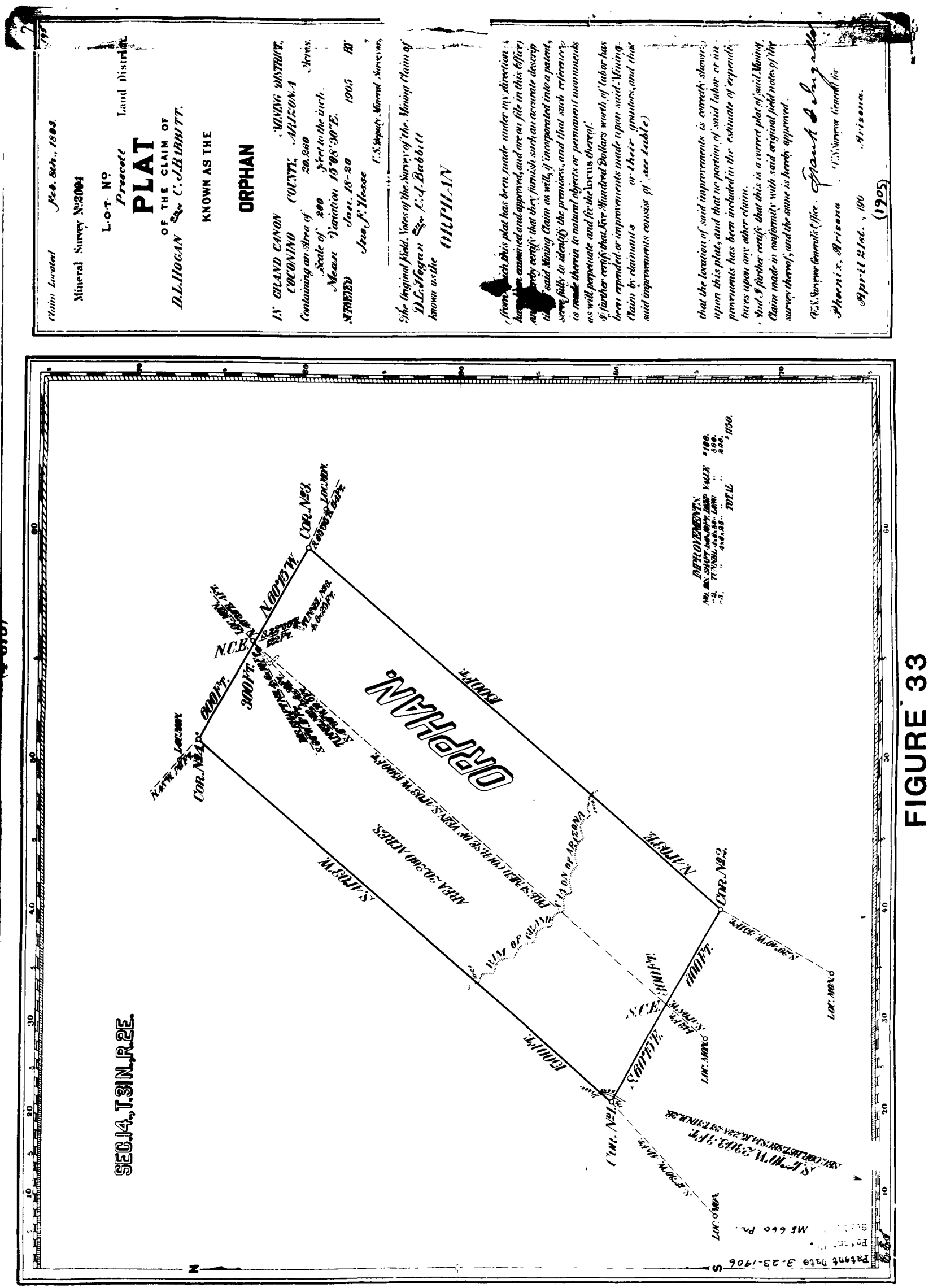
Western Gold \& URANiom. Ing.

42 BROAOWAY

NEW YORK 4. N. Y.

WHITEMALL 4.6478

SILVER REEF URANIUM MINES ORTEE: LEEDS, UTAH

December 14,1955

FIRST NATIONAL BANK BUILDING CAABON CITY, NEYADA

TO TEE STOCKEOLDERS:

Two notable developments in the company's recent operations make this interim report to shareholders advisable.

First, the ORPBAN property of Colden Crown Mining Co., in wh1ch Western owns a controlling 1nterest, has now proved to be a primary uranium strike of mor proportlons. Dlamond drilling thus far bas not been sufflclent to prove the ent1re structure. However, the company's geological staff has indicated that the structure is of a pipe nature; mineralization has occurred around the perimeter of the structure with mineable vein widths of 30 to 40 feet. The deposit is in a mineralized shear zone of Coconino sandstone of Permian age. The mineral is pitchblende.

Thus far an ore body of not less than 100,000 tons is 1nd1cated, but your management belleves that ore may well reach 300,000 tons or more (based on a minimum of 500 feet of perimeter $X$ vein width of 30 feet $X$ vertical height of 280 feet $=4,200,000$ cubic feet, divided by 14 cubic feet per ton $=300,000$ tons.) At an average probable grade of $.45 \%$ uranium oxide, anticipated profits would be approximately $\$ 30$ per ton.

The foregoing expectations do not include possibilities for additional depth snd height (hole No. 11 went down 217 feet and was still in the mineralized area), nor the possibllity of finding ore within the heart of the pipe structure.

The Orphan thus appears to be one of about 25 uranium finds in the U.S. of more than 100,000 tons, and also one of the very few sizeable pitchblende deposits found in this country. Because the ore body is many times the size originally expected, initial production will be delayed somewhat, with the first ore to be marketed in the spring. It will be trucked 85 miles to the new AEC ore-buying station at Tuba City, Arizons.

Secondly, since our September 26 report, Western bas started to develop 1ts SILVER REEF property in Southwestern Utah, where 36,000 tons or uranium-silver ore has been blocked out. A 125-foot shaft to the ore body is well under way and will be completed In about two months. A new holst house has been constructed near the shaft and the holst Installed; a carpenter shop, change room, water tank and oll tank also have been installed. Initially, that portion of the ore high in uranium content but low in silver will be shipped to an AEC ore-buylng station, while the silver-rich ore will be shipped to a silver smelter. The great bulk of the ore, which contains about equai values of uranium and silver, w1ll, however, be held for treatment in a. silver flotat1on mill to extract the silver before it is shipped to the AEC. A 50-ton-8-day mill will be built next spring. For your further information, we are enclosing a detalled sumary of the compapyi58728 293
present status which we belleve will be both interesting and helpful.
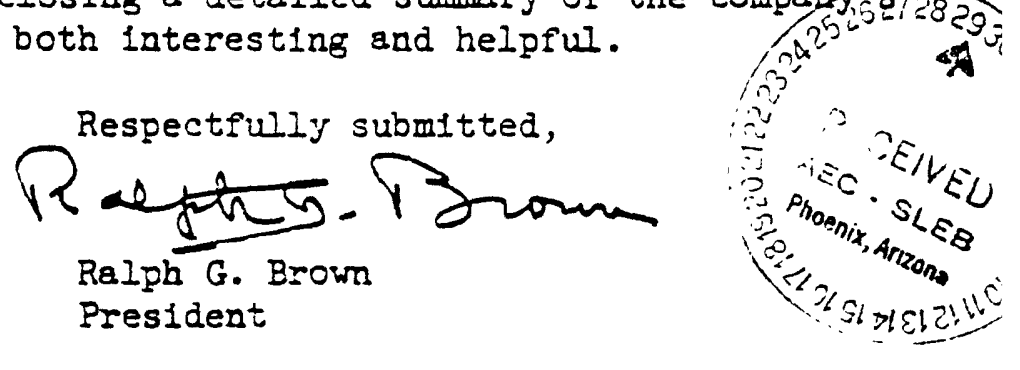


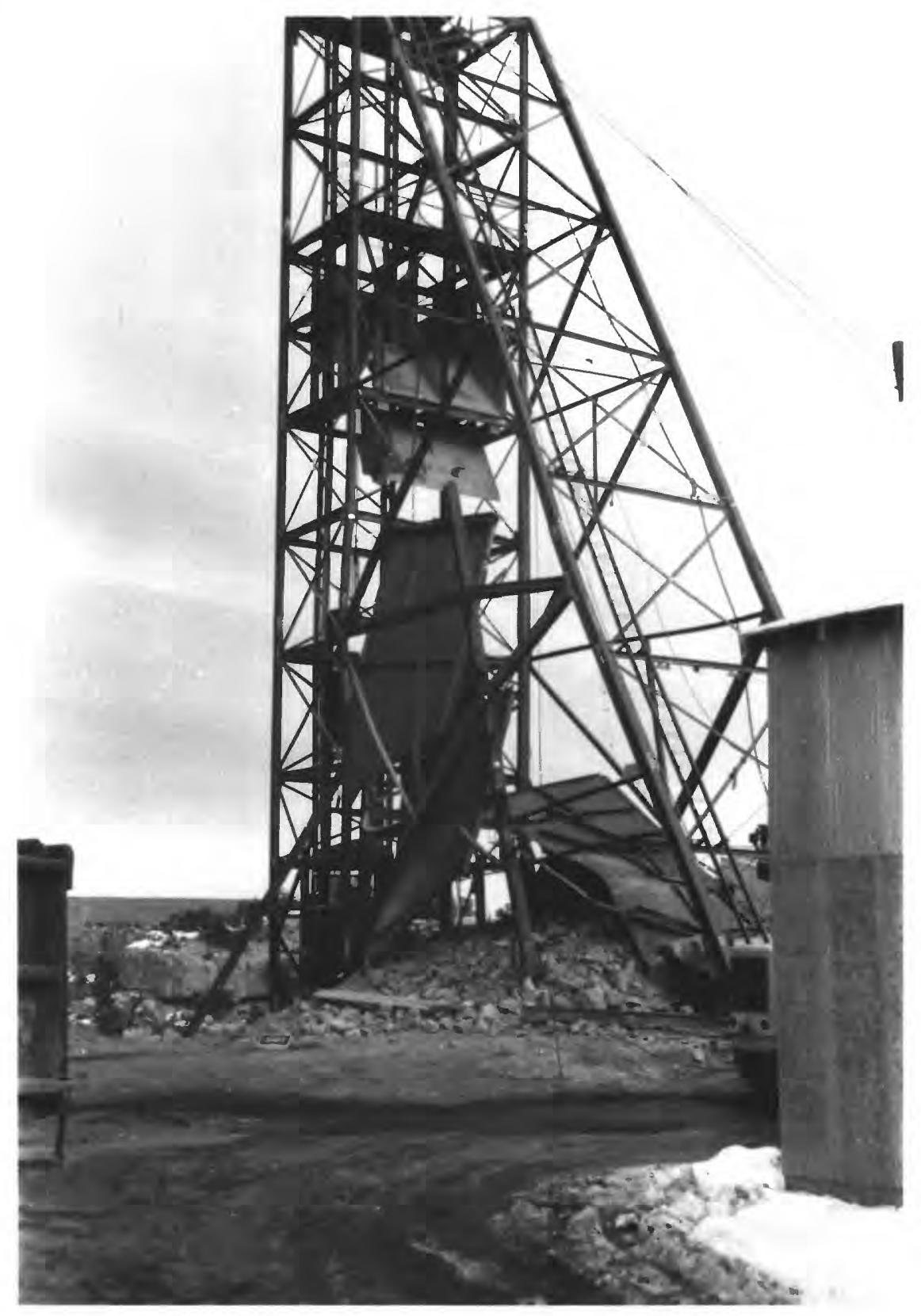

Figure 34

Photo of the collapsed ore bin at the Orphan Lode Mine, which occurred on December 22, 1961, closing the mine for several months. Photos by W. L. Chenoweth. 


\section{PETROGRAPHIC REPORT}

Sample Nos: 2002-A, B, C

Location: Coconino Sandstone, Adit level, Orphan Lode Mine, Coconino County, Arizona, Collected by R. D. Miller

Information Desired: Mineral identification, paragenesis

Type of Examination: Thin and polished sections, oil immersion, chemical tests, heavy mineral separations, $x-r a y$ and spectrographic analyses, autoradiographs, assays.

Petrography: Three samples were submitted. Since the relationship of one sample to another is unknown, the results are reported separately below.

Megascopically, sample $A$ is a dark-gray, fine-grained, impure sandstone. Observed in thin section, the detrital grains consist approximately of 75 percent quartz and 25 percent mudstone and siltstone fragments, with accessory amounts of muscovite, zircon, tourmaline, feldspar, chalcedony, and magnatite. The quartz grains are rounded to angular and vary in size from less than $.01 \mathrm{~mm}$. to greater than $1 \mathrm{~mm}$. The mudstone and siltstone fragments have been flattened and wrapped around the quartz grains. Thin layers of mudstone and siltstone are also interlayered with the sandstone layers.

Sample $A$ is cemented mostly by a mixture of fine rock flour (mainly clay and quartz) and brown to black carbonaceous matter. Minor cementing agents are pyrite, uraninite, chalcocite (?), covellite, and a green secondary uranium mineral. The metallic minerals are in irregular masses and are too fine-grained and widely dispersed to determine their interrelations. The secondary uranium mineral occurs as square plates where space allows and appears bladed in thin section. Indices and $x-r a y$ analysis place it between metatorbernite and metazeunerite in composition. The unit cell is larger than that of metatorbernite and smaller than that of metazeunerite, but closer to metazeunerite, which is what it will be called in this paper. Chemical analysis would probably show a substitution of $\mathrm{P}$ for As.

Sample B is a yellow, poorly sorted, medium-grained sandstone. Grain size varies from less than $.01 \mathrm{~mm}$. to greater than $1 \mathrm{~mm}$. Thin section shows that the detritals are mostly quartz, with accessory amounts of chalcedony, feldspar, tourmaline, and magnetite. Barite was introduced some time after deposition of the original sand. Euhedral blades up to 5 or $6 \mathrm{~mm}$. in length have replaced quartz grains and have intergrown with each other. The barite is weakly pleochroic from pale yellow to colorless. 
Sample No: 2002-A, B, C continued

Sample $B$ is cemented mainly by carphosiderite, $\left[\left(\mathrm{H}_{2} \mathrm{O}\right) \mathrm{Fe}_{3}-\right.$ $\left.\left(\mathrm{SO}_{4}\right)_{2}\left[(\mathrm{OH})_{5} \mathrm{H}_{2} \mathrm{O}\right]\right]$, although oriented overgrowths of quartz have filled the spaces between detritals in places. The carphosiderite has corroded and replaced the quartz grains until the original shape of the detrital particles is no longer discernible. In places the carphosiderite has also replaced barite, separating crystals into several irregularlyshaped islands with the same optical orientation. Metazeunerite also occurs in sample B, but was not observed in thin section. As studied under the binocular microscope, it appears to be clearly associated with barite and to have preceded the deposition of carphosiderite.

Spectrographic analyses were run on two fractions from sample B: (1) that fraction heavier than methylene iodide and (2) the fraction lighter than methylene iodide and heavier than acetylene tetrabromide. The results were as follows:

$\begin{array}{lll}\mathrm{Si} & 3 . & \mathrm{M}^{2} \\ \mathrm{Al} & .15 & .15 \\ \mathrm{Fe} & 7 . & 7.007 \\ \mathrm{Mg} & .0015 & .007 \\ \mathrm{Ca} & .005 & .015 \\ \mathrm{~K} & .7 & .7 \\ \mathrm{Ti} & .07 & .15 \\ \mathrm{Ag} & .007 & .007 \\ \mathrm{As} & 3.00 & 7 . \\ \mathrm{Ba} & \mathrm{M} & 7.0015 \\ \mathrm{Co} & .003 & .0015 \\ \mathrm{Cr} & .007 & .007 \\ \mathrm{Cu} & .3 & .7 \\ \mathrm{Ga} & .007 & .007 \\ \mathrm{Me} & .03 & .07 \\ \mathrm{Ni} & .007 & .007 \\ \mathrm{~Pb} & 3.0015 & 7.0015 \\ \mathrm{Se} & .0015 & .0015 \\ \mathrm{Sr} & 1.5 & .03 \\ \mathrm{U} & .15 & .07 \\ \mathrm{~V} & .007 & .07 \\ \mathrm{Zn} & .07 & .03 \\ \mathrm{Zr} & .015 & .015\end{array}$

Except for $\mathrm{Pb}$, the major elements can be accounted for by the mineral assemblage presented above. Possibly $\mathrm{Pb}$ is present as the sulfate and is intermixed with the carphosiderite.

Sample $\mathrm{C}$ is a fine-grained black sandstone. The detritals, which are sorted better than those in Samples A and B, are mostly quartz, with accessory feldspar, tourmaline, and zircon. The grain size varies from .05 to $.4 \mathrm{~mm}$. with an average size of about .2 mm. The grains are angular to 
Sample No: 2002-A, B, C continued

subrounded. The detrital particles are cemented by carbonaceous matter, oriented quartz overgrowths, rare clay, minor calcite, pyrite, chalcocite (?), covellite, uraninite, and metazeunerite. Sample C contains a much larger percentage of the metallic minerals, especially uraninite and covellite. However, just as in sample $A$, they occur in minute, disseminated masses which are impossible to polish well enough to determine any paragenetic relations.

Radiometric and chemical assays on the three samples gave the following results:

Sample No:

2002-A

2002-B

2002-C

Examined by:

$\begin{array}{rrr}8 \mathrm{U}_{3} \mathrm{O}_{8} & 8 \mathrm{eU}_{3} \mathrm{O}_{8} & 8 \mathrm{Cu} \\ 1.24 & 2.75 & .23 \\ .93 & .93 & .45 \\ 1.83 & 1.70 & .90\end{array}$

Alice S. Corey, Petrographer

U. S. Atomic Energy Commission Grand Junction Operations Office March 18, 1957 


\section{PETROGRAPHIC REPORT}

Sample No: 3696

Location: Muav Limestone, Core sample from hole P-13, a vertical hole drilled to a T. D. of 1,914 feet from 550 level, Orphan Lode Mine, Coconino County, Arizona. Submitted by John W. Gabelman

Information Desired: Petrography. Identification of green mineral. Is there evidence of brecciation? Is there evidence of mineralization?

Type of Examination: Thin section; polished thin section; microscope, oil immersion.

Petrography: The rock is a sandy, glauconitic, dolomitic limestone. Much of the carbonate was probably originally detrital. Other principal detrital minerals are quartz, feldspar, and muscovite. Glauconite might be considered syngenetic, since it was probably formed about the time the detrital minerals were accumulating. Here, part of the glauconite appears to have originated by alteration of biotite, some biotite being incompletely altered to glauconite; but some of the glauconite appears to replace organic remains.

The rock consists principally of dolomite, but some calcite is also present. Determination of relative proportions of calcite and dolomite is impossible without special methods, but minute rhomboidal crystals are mostly dolomite, whereas larger anhedral crystals are calcite. Essentially all of the carbonate shows evidence of recrystallization. Ghosts of rounded detrital grains can be seen in some of the euhedral to subhedral dolomite crystals. Euhedral dolomite crystals project into anhedral masses of calcite which appear to fill former voids. This, plus the presence of ghosts of rhombic carbonate crystals (probably dolomite) in the calcite masses, indicates that the calcite is probably younger than the dolomite. However, there may also have been dolomitization of original calcite and/or aragonite in shell fragments at an earlier stage in the history of this rock.

Hematite (and goethite?) in minute rounded blebs forms irregular, discontinuous dark, slightly purplish stringers through the rock. The iron oxide mineral(s) is closely associated with glauconite.

In hand specimen, and especially in thin section, the rock shows irregular blotching on a megascopic scale. Although less noticeable under the microscope, these blotches are seen to be formed of more or less rounded masses of varying composition. Perhaps most commonly, the rounded masses are pebbles or grains of nearly pure carbonate in a more sandy and glauconitic matrix. 
Sample No: 3696 continued

The rock appears to be one of the types described by L. F. Noble (1923, A section of the Paleozoic formations of the Grand Canyon at Bass trail: USGS Prof. Paper 131, pp. 23-73) as part of the Muav section, which he considered to be an intraformational conglomerate or clastic limestone (dolomitic in part). No features were observed which appear inconsistent with Noble's interpretation, although there is abundant evidence of recrystallization.

Since Noble's description mentions such features as intraformational conglomerate, cross bedding, worm burrows, and broken brachiopod shells, the rather fragmental structures and irregular distribution of minerals in the specimen as seen megascopically may be accounted for by these features. No angular breccia fragments were observed, nor any other features which would indicate (in a specimen of this size) postdepositional brecciation of the zone from which this sample was taken.

No evidence of mineralization nor introduction of extrinsic elements, except perhaps magnesium to form dolomite, was found. However, spectrographic analysis is pending. The only metallic mineral seen is hematite (goethite?), which Noble notes as being abundant enough in parts of the section he describes to impart a purple color to the rock. Thus the small amount of hematite present here does not indicate extrinsic mineralization.

Glauconite was identified both by oil immersion and in thin section, but confirmation by $x-r a y$ is also being sought.

Examined By:

S. Ralph Austin, Petrographer

U. S. Atomic Energy Commission

Grand Junction Operations office

March 14, 1962 


\section{SEMIQUANTATIVE SPECTROGRAPHIC ANALYSIS}

Sample of Muav Limestone from core hole P-13, Orphan Lode Mine, Coconino County, Arizona.

\begin{tabular}{|c|c|c|c|}
\hline Element & Percent & Element & Percent \\
\hline Al & B & Mn & D \\
\hline $\mathrm{Ba}$ & D & $\mathrm{Na}$ & C \\
\hline $\mathrm{Ca}$ & A & $\mathrm{Ni}$ & D \\
\hline $\mathrm{Cr}$ & $\mathrm{E}$ & $\mathrm{Pb}$ & D \\
\hline $\mathrm{Cs}$ & $E$ & $\mathrm{Rb}$ & D \\
\hline $\mathrm{Cu}$ & D & $\mathrm{Si}$ & A \\
\hline $\mathrm{Fe}$ & B & $\mathrm{Sr}$ & D \\
\hline $\mathrm{Ga}$ & E & $\mathrm{Ti}$ & C \\
\hline $\mathrm{K}$ & B & $\mathrm{v}$ & D \\
\hline $\mathrm{Li}$ & $E$ & $\mathrm{zr}$ & D \\
\hline Mg & A & & \\
\hline
\end{tabular}

Code: A - Probably greater than 10\%

B - Probably 1 - $10 \%$

C - Probably 0.1 - $1 \%$

D - Probably $0.01-0.1 \%$

E - Probably $0.001-0.01 \%$

Not detected: Ag, As, Au, B, Be, Bi, Cd, Ce, Co, Ge, Hf, Hg, In, Ir, La, Mo, $\mathrm{Nb}, \mathrm{Os}, \mathrm{P}, \mathrm{Pd}, \mathrm{Pt}, \mathrm{Re}, \mathrm{Rh}, \mathrm{Ru}$, $\mathrm{Sb}, \mathrm{Sc}, \mathrm{Sn}, \mathrm{Ta}, \mathrm{Te}, \mathrm{Th}, \mathrm{Tl}, \mathrm{U}, \mathrm{W}, \mathrm{Y}, \mathrm{Zn}$.

Anaylsis by U.S. Bureau of Mines, Salt Lake City, Utah, March 1962 


\section{PETROGRAPHIC REPORT}

Sample No: 3954

Location: Coconino Sandstone, A stope, 175 Level, Orphan Lode Mine, Coconino County, Arizona. Collected by $W$. L. Chenoweth.

Information Desired: Mineral identification, texture description paragenesis, spectrogram, radiochemical analysis, relation of Fe oxides to $\mathrm{U}$ and $\mathrm{Cu}$. Is pyrite present? Secondary enrichment of $U$ and $\mathrm{Cu}$ ?

Type of Examination: Polished thin section; microscope, oil immersion; $\mathrm{x}-\mathrm{ray}$; chemical tests, contact print tests.

Petrography: Minerals observed comprise: detrital quartz; pyrite; sphalerite; galena; gersdorffite (?); coffinite (?) or sooty uraninite (?); hematite and other iron oxides; an unidentified secondary uranium mineral, probably a uranyl arsenate; possibly, gummite; and perhaps orpiment and/or realgar; also an unidentified transparent mineral, probably an iron sulfate.

\section{Detrital Quartz}

The sandstone host rock consists largely of quartz grains, and no attempt was made to identify other detrital minerals.

\section{Pyrite}

Pyrite is present in minute, euhedral to anhedral crystals attached to and partly replacing detrital grains. Only rarely does a single crystal of pyrite entirely fill interstices between detrital grains or form masses large enough to enclose several grains; but interstices may be filled with pyrite aggregates. Commonly the pyrite is at least as yeliow as ordinary pyrite and therefore does not appear to be either nickelian or cobaltian. However, minute cubic crystals, yellowish with a violet tint, found within gersdorffite (?) may be nickelian pyrite. The ordinary pyrite appears to be the earliest to form of the authigenic minerals.

\section{Sphalerite}

Sphalerite occurs in large euhedral to subhedral crystals up to at least five millimeters across. Most of these enclose many sand grains, thus producing luster mottling similar to that produced by coarsely crystalline calcite cement. Most of the sphalerite crystals poikilitically enclose pyrite; thus, the sphalerite is believed to be younger than the pyrite. However, the boundaries of individual sphalerite crystals can scarcely be discerned under the microscope, although they are plainly visible to the naked eye in polished section when viewed at the proper angle. The 
Sample No: 3954 continued

sphalerite is light colored, possibly the variety, cleiophane. Since the sphalerite appears to be distinctly younger than the pyrite, the light color of the sphalerite may or may not indicate low temperature.

Galena

Galena occurs sparsely in aggregates up to about a millimeter across, consisting of nearly euhedral crystals. In some instances, galena is idiomorphic against sphalerite, but in the same mass, intergrowths resembling rim textures also occur between the two minerals. However, the fact that either or both minerals may have replaced detrital grains complicates attempts at deciphering the relationships. On the basis of conflicting evidence, galena and sphalerite are considered to be penecontemporaneous.

\section{Gersdorffite (?)}

Contact print tests for nickel revealed the presence of a nickel mineral resembling galena in appearance, but less reflective, which has been tentatively identified as gersdorffite. This mineral occurs in crystals whose maximum size is about that of the detrital grains. Some of these are anhedral and appear to replace detrital grains; whereas, smaller crystals occur interstitially and show more tendency to be euhedral. The mineral develops pits, on polishing, similar to those developed in galena, but triangular pits tend to be less sharply defined and equilateral than those in galena, and many of the pits are elongate with essentially parallel sides. Gersdorffite (?) shows relationships with sphalerite similar to those shown by galena and is believed to be about the same age.

Low Valence Uranium Mineral

Primary (?) uranium occurs in black material which takes no polish whatever. In the absence of $x$-ray work, no identification of this mineral was possible, but coffinite or sooty uraninite, or both may be present. Uranium is largely concentrated outside the sphalerite, which has some tendency to poikilitically enclose all other primary minerals, so that the black uranium minerals, if primary (see below), are believed to be the last of the primary suite to be emplaced.

Hematite and Other Iron Oxides

Red hematite occurs as cement in masses of sandstone, up to an inch or more in longest dimension, surrounded by yellow material consisting of "limonite" and other secondary 
minerals. These masses of red and yellow sandstone appear to be entirely insular within the black, main body of the rock, at least as far as could be determined from the sample submitted. This apparent insular character makes their origin more difficult to explain. The hematite takes an excellent polish and is opaque or translucent in thin section.

Unidentified Secondary Uranium Mineral

Among the yellow materials is a secondary uranium minerals, unidentified either optically or by $x$-ray. The X-ray powder pattern resembles, in a general way, the patterns of uranyl phosphates and arsenates in our files and those indicated for minerals of these groups by data in USGS Bulletin 1064, but corresponds to none of them. The ammonium molybdate test indicates that the mineral is probably a uranyl arsenate rather than a phosphate, as also might be expected from the presence of considerable arsenic and the absence of detectable phosphorous shown in spectrographic analysis of the rock. The mineral occurs in sheaf-like aggregates of platy crystals. Either this mineral or one closely associated therewith fluoresces moderately under ultraviolet light.

"Gummite"

Among the yellow materials surrounding the hematite and intimately mixed with limonite are uraniferous materials here identified as "gummite".

Orpiment (?) and Realgar (?)

Because of the arsenic content of the rock and the color of some of the yellow to orange materials surrounding hematite masses, the presence of realgar and/or orpiment seems possible. However, no discrete mineral resembling either in thin section could be discerned.

Unidentified Transparent Mineral

An acicular or fibrous, transparent mineral occurring within the hematite-limonite masses is as yet unidentified. This mineral shows moderate birefringence and resembles some of the iron sulfate minerals which might be expected in this association.

Secondary Enrichment and Related Problems

Results of semiquantitative spectrographic analysis $10.07 \%$ $\mathrm{Cu})$ indicate that any secondary enrichment of copper has been insignificant. Whether secondary enrichment of uranium ever occurs in nature is, in my opinion, still a debatable question. 
Sample No: 3954 continued

However, if secondary enrichment is possible, what chemical and physical processes other than those involved therein are necessary for the formation of all plateau-type deposits?

In the present instance, the apparent insular character of the hematite-limonite masses would tend to favor the conclusion that they are remnant enclaves of oxidized minerals left from the sulfidization and reduction of the mass of the rock. However, the presence of minerals other than the iron oxides and consideration of the chemistry involved in their alteration to those found in sulfidized and reduced (or unoxidized) parts of the rock makes normal oxidation seem the more likely process.

For example, the reduction of a uranyl arsenate mineral to form coffinite or uraninite, with concomitant reduction of arsenic and its combination with nickel (which just happened to be coming along) to form gersdorffite, seems much less likely by supergene processes than does the formation of uranyl arsenate by oxidation of coffinite or uraninite and gersdorffite.

Similarly, if my tentative identification of an iron sulfate mineral within the hematite-limonite masses is correct, it would be a normal product (in association with hematite and limonite) of the supergene oxidation of pyrite.

\section{Paragenesis}

Early Late

Detrital grains

Pyrite

Reduced

Oxidized

Sphalerite

Galena

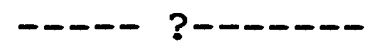

Gersdorffite (? )

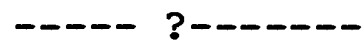

Uraninite or coffinite

Limonite

Gummite

Uranyl arsenate mineral

Iron sulfate mineral (?)

Hematite 
Sample No: 3954 continued

Examined By:

S. Ralph Austin, Petrographer

U. S. Atomic Energy Commission

Grand Junction Operations Office March 27, 1961 


\section{ANAL YTICAL DATA}

225 Level

\begin{tabular}{|c|c|c|c|c|c|}
\hline SAMPLE NO. & LAB • NO. & $\mathrm{ppmU}_{3}{ }^{0}$ & ${ }^{8} \mathrm{eU}_{3}{ }^{0} 8$ & ${ }^{8} \mathrm{P}_{2}{ }^{0} 5$ & ${ }_{8}^{8 \mathrm{SO}_{4}}$ \\
\hline 4335 & 66350 & 9 & .002 & .04 & .01 \\
\hline
\end{tabular}

Sample is red Supai sandstone, in breccia, within pipe. Coordinates $6110 \mathrm{~N} \quad 5548 \mathrm{E}$

Analysis by Lucius Pitkin, Inc., September 1964 


\section{ANAL YTICAL DATA}

\section{Level}

\begin{tabular}{|c|c|c|c|c|c|}
\hline SAMPLE NO. & LAB . NO. & $\mathrm{ppmU}_{3}{ }^{0} 8$ & ${ }_{8} \mathrm{eU}_{3}{ }^{0} 8$ & ${ }^{8} \mathrm{P}_{2} \mathrm{O}_{5}$ & ${ }^{8 \mathrm{SO}_{4}}$ \\
\hline $4336 \mathrm{~A}$ & 66351 & 19 & .001 & .02 & .01 \\
\hline $4336 \mathrm{~B}$ & 66352 & 44 & .008 & .02 & .01 \\
\hline
\end{tabular}

Samples of red Supai sandstone outside of pipe

Coordinates A $5941 \mathrm{~N}$

$5295 \mathrm{E}$

B $5791 \mathrm{~N} \quad 5392 \mathrm{E}$

Analysis by Lucius Pitkin, Inc., September 1964 


\section{ANALYTICAL DATA}

400 Level

SAMPLE NO.

LAB. NO.

$\underline{p^{2} U_{3}{ }^{0}}$

$\mathrm{geU}_{3}{ }^{0} 8$

${ }_{8}^{8} \mathrm{P}_{2} \mathrm{O}_{5}$

${ }^{850} 4$

4337 A

66353

5

.001

.04

.01

4337 B

66354

4

.001

.06

.01

$4337 \mathrm{C}$

66355

$4337 \mathrm{D}$

66356

$4337 \mathrm{E}$

66357

$4337 \mathrm{~F}$

66358

84

.005

.02

.03

72

.009

.04

.04

24

.002

.05

.18

.012

.05

1.42

Set of samples collected along the main haulageway on the 400 level where it enters the pipe.

$$
\begin{aligned}
& \text { A- red Supai sandstone } \\
& \text { B- red Supai sandstone } \\
& \text { C- red Supai sandstone } \\
& \text { D- gray Supai sandstone } \\
& \text { E- breccia } \\
& \text { F- breccia }
\end{aligned}
$$

Coordinates $5004 \mathrm{~N}, 5018 \mathrm{E}$

$5679 \mathrm{~N}, 5252 \mathrm{E}$

$5858 \mathrm{~N}, 5363 \mathrm{E}$

$5882 \mathrm{~N}, 5371 \mathrm{E}$

$5929 \mathrm{~N}, 5413 \mathrm{E}$

$5994 \mathrm{~N}, 5470 \mathrm{E}$

Analysis by Lucius Pitkin, Inc., September 1964. 


\section{ANALYTICAL DATA}

HOLE $\mathrm{K}-13$

SAMPLE NO. LAB. NO. $\operatorname{ppmU}_{3}{ }^{0} 8$

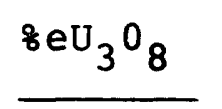

${ }^{8} \mathrm{P}_{2} \mathrm{O}_{5}$

$8_{4} \mathrm{SO}_{4} \quad$ INTERVAL

4338 A

66360

12

.002

.05

$.07 \quad 141.0-141.5$

$4338 \mathrm{~B}$

66361

2500

.15

.03

$.30166 .5-167.0$

$4338 \mathrm{C}$

66362

$4338 \mathrm{C}$

66363

23

.001

.07

$.01 \quad 175.0-175.5$

9

.001

.07

$.01 \quad 179.5-180.0$

$\mathrm{K}-13$ was an inclined core hole drilled from the 400 level, bearing $\mathrm{N} 55^{\circ} \mathrm{E}$, inclined $-30^{\circ}$, total length 200 feet.

Samples were splits of core, and were from within the pipe.

$$
\begin{aligned}
& \text { A- partly altered Supai sandstone } \\
& \text { B- ore-bearing supai sandstone } \\
& \text { C- gray Supai sandstone } \\
& \text { D- red Supai sandstone }
\end{aligned}
$$

Analysis by Lucius Pitkin, Inc., September 1964 


\title{
ANALYTICAL DATA
}

\author{
HOLE P-10
}

SAMPLE NO. LAB. NO.

$\mathrm{ppmU}_{3} 0_{8}^{8}$

$8 \mathrm{eU}_{3} \mathrm{O}_{8}$

$$
{ }^{8} \mathrm{P}_{2} \mathrm{O}_{5}
$$

${ }^{8} \mathrm{SO}_{4}$

INTERVAL

$\begin{array}{rlrrrrrr}4339 \mathrm{~A} & 66363 & 14 & .001 & .02 & .01 & 306.5-309.5 \\ 4339 \mathrm{~B} & 66364 & 115 & .006 & .02 & .02 & 330.0-331.0 \\ 4339 \mathrm{C} & 66365 & 12 & .001 & .22 & \operatorname{Tr} & 394.0-396.0\end{array}$

P-10 was an inclined core hole drilled from the 550 level, bearing $\mathrm{S} 59^{\circ} \mathrm{E}$, inclined $-55^{\circ}$, length 396.0 feet. Pipe contact at 382 feet.

Samples are splits of core.
A- brecciated gray Supai sandstone
B- limonite staining in gray Supai sandstone
C- red unaltered Supai sandstone

Analysis by Lucius Pitkin, Inc., September 1964 


\section{ANALYTICAL DATA}

\section{HOLE P-11}

SAMPLE NO. LAB. NO. $8 \mathrm{U}_{3} \mathrm{O}_{8}{ }^{8 \mathrm{eU}} \mathrm{U}_{3} \mathrm{O}_{8}$ ${ }^{8 \mathrm{CaCO}_{3}} \quad{ }^{8 \mathrm{P}_{2} \mathrm{O}_{5}} \quad{ }^{8 \mathrm{Cu}} \quad{ }^{8 \mathrm{~F}} \quad{ }^{8 \mathrm{SO}_{4}} \quad$ INTERVAL

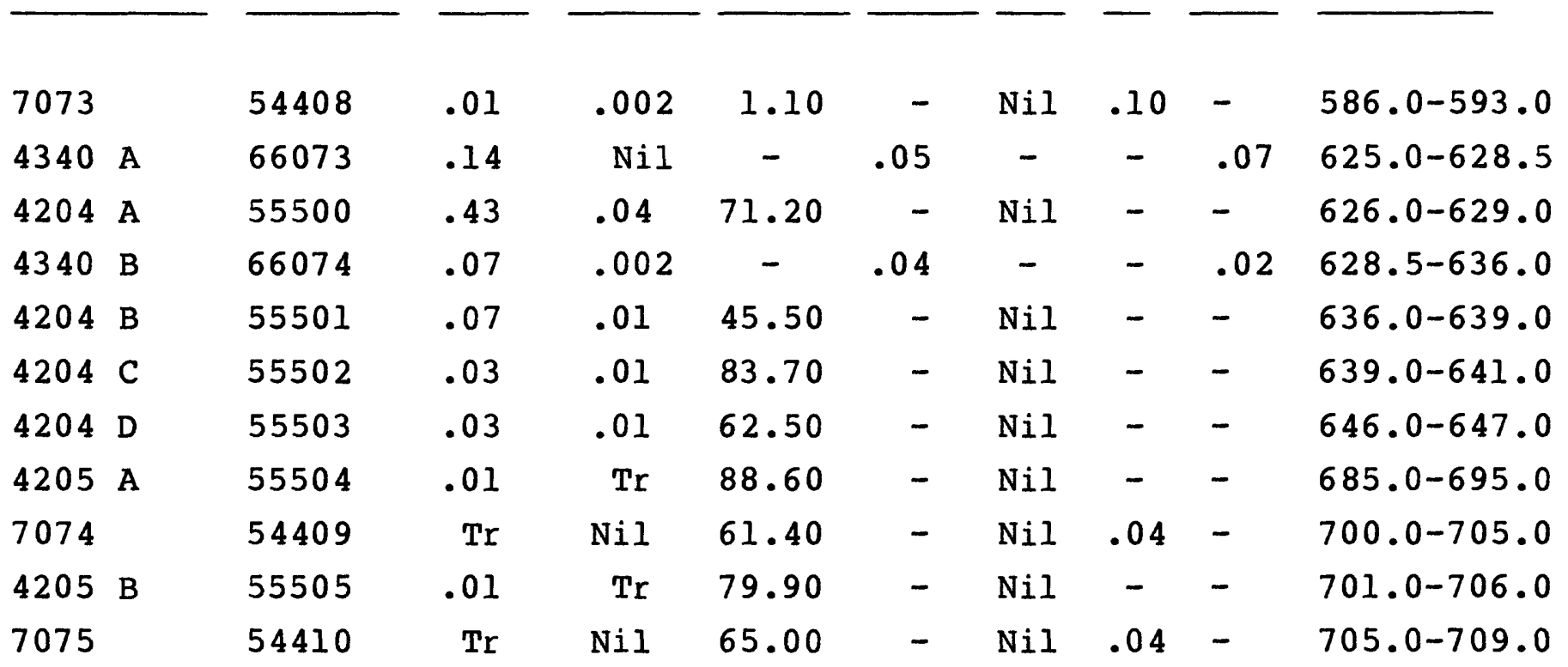

P-1l was an inclined core hole drilled from the 550 level, bearing $N 60^{\circ} \mathrm{E}$, inclined $-61^{\circ}$, total length 709 feet. Purpose was to test the lower supai rocks outside the pipe.

Limestone breccia encountered at 625 feet. Unbrecciated limestone in the Manakacha Formation, of the Supai Group, penetrated at 651 feet.

Samples were splits of core, except samples 4340, 7073-7075 which were pulps of core.

Due to the radiometric disequilibrium in sample $4204 \mathrm{~A}$, the following analyses were determined:

Percent equivalent Thorium $230-.06 \%$

Percent equivalent Radium $226-.0048$

Percent equivaltne Polonium 210 - .00048

Analysis by Lucius Pitkin, Inc., December 1963, Sample 4340 analyzed September 1964. 


\section{ANALYTICAL DATA}

HOLE P-12

SAMPLE NO. LAB. NO. $8 \mathrm{U}_{3} \mathrm{O}_{8} 8 \mathrm{eU}_{3} \mathrm{O}_{8} \& \mathrm{CaCO}_{3} \& \mathrm{P}_{2} \mathrm{O}_{5} \& \mathrm{Cu} \quad \& \mathrm{~F} \quad \& \mathrm{SO}_{4}$ INTERVAL

\begin{tabular}{lcccccccccccc}
\hline & & & & & & & & & & & & \\
4341 & 66064 & 24 & $\mathrm{ppm}$ & .01 & - & .02 & - & - & .05 & $379-380$ \\
7076 & 55411 & .01 & .006 & 2.40 & - & $\mathrm{Nil}$ & .06 & - & $657-662$ \\
7077 & 55412 & .02 & .02 & 1.20 & - & .04 & .12 & - & $662-667$ \\
7078 & 55413 & .01 & .004 & 0.60 & - & $\mathrm{Nil}$ & .12 & - & $710-715$ \\
7079 & 55414 & $\operatorname{Tr}$ & .005 & 0.80 & - & $\mathrm{Nil}$ & .12 & - & $715-720$ \\
7080 & 55415 & $\operatorname{Tr}$ & .005 & 0.70 & - & $\mathrm{Nil}$ & .10 & - & $720-725$ \\
7081 & 55416 & $\operatorname{Tr}$ & .004 & 0.30 & - & $\mathrm{Nil}$ & .06 & - & $725-730$
\end{tabular}

$\mathrm{P}-12$ was an inclined core hole drilled from the 550 level, bearing $\mathrm{N} 46^{\circ} \mathrm{W}$, inclined $-55^{\circ}$, total length 746 feet. No limestone breccia encountered. Last 50 feet of core is of unbrecciated sediments, mostly sandstone, but still believed to be within the pipe.

Samples were pulps of core.

Analysis by Lucius Pitkin, Inc., December 1963. Sample 4341 analyzed September 1964 . 
ANAL YTICAL DATA

HOLE P-13

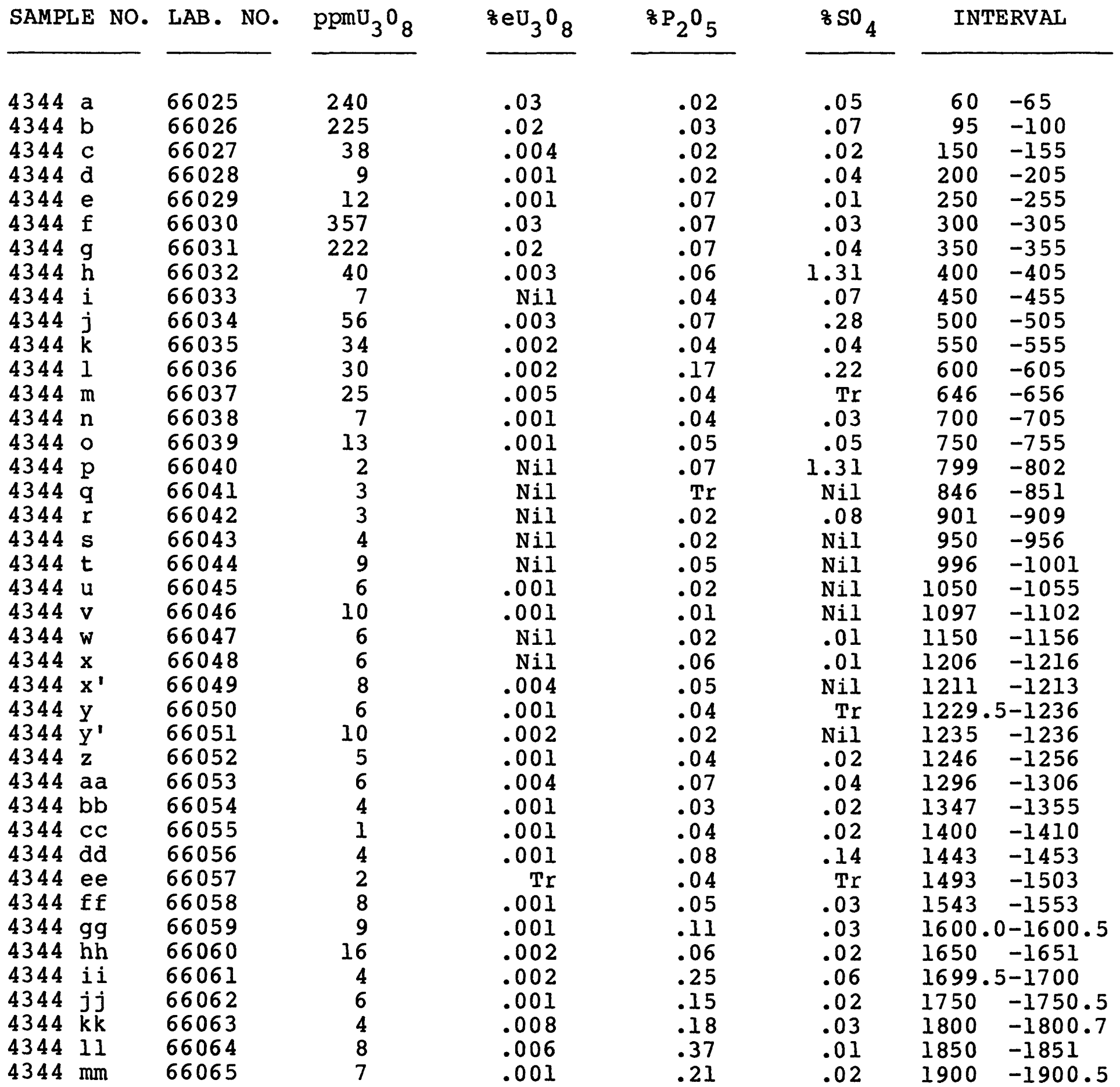


P-13 Continued

P-13 was a vertical core hole drilled from the 550 level to a total depth of 1,914 feet. Purpose was to test the origin and extent of the pipe.

Unbrecciated Redwall Limestone was encountered at 761 feet. The top of the Bright Angel Shale was at 1,515 feet and the top of the Tapeats Sandstone was at 1,854.4 feet.

Samples were pulps of core, except samples $4344 x^{\prime}$ and $y^{\prime}$ which were splits of core.

Analysis by Lucius Pitkin, Inc., September 1964 


\section{ANALYTICAL DATA}

HOLE 400-3

\begin{tabular}{|c|c|c|c|c|c|c|}
\hline SAMPLE NO. & LAB - NO. & $\mathrm{ppmU}_{3}{ }^{0} 8$ & $8 \mathrm{eU}_{3}{ }^{0} 8$ & ${ }^{8} \mathrm{P}_{2}{ }^{0} 5$ & $8 \mathrm{SO}_{4}$ & INTERVAL \\
\hline $4342 \mathrm{~A}$ & 66066 & 2 & .002 & .06 & $\operatorname{Tr}$ & $135.5-136.0$ \\
\hline 4342 B & 66067 & 5 & $\mathrm{Nil}$ & .02 & .04 & $157.0-157.5$ \\
\hline $4342 \mathrm{C}$ & 66068 & 2 & $\mathrm{Nil}$ & .05 & .01 & $164.0-164.5$ \\
\hline
\end{tabular}

Hole 400-3 was a vertical core hole drilled from the 400 level to a depth of 210 feet. It was planned to test the 585 ore horizon.

Samples were splits of core.

A- red Supai sandstone

B- gray (bleached) supai sandstone

C- red Supai sandstone

Analysis by Lucius Pitkin, Inc. September 1964 


\section{ANALYTICAL DATA}

\section{HOLE 550-6}

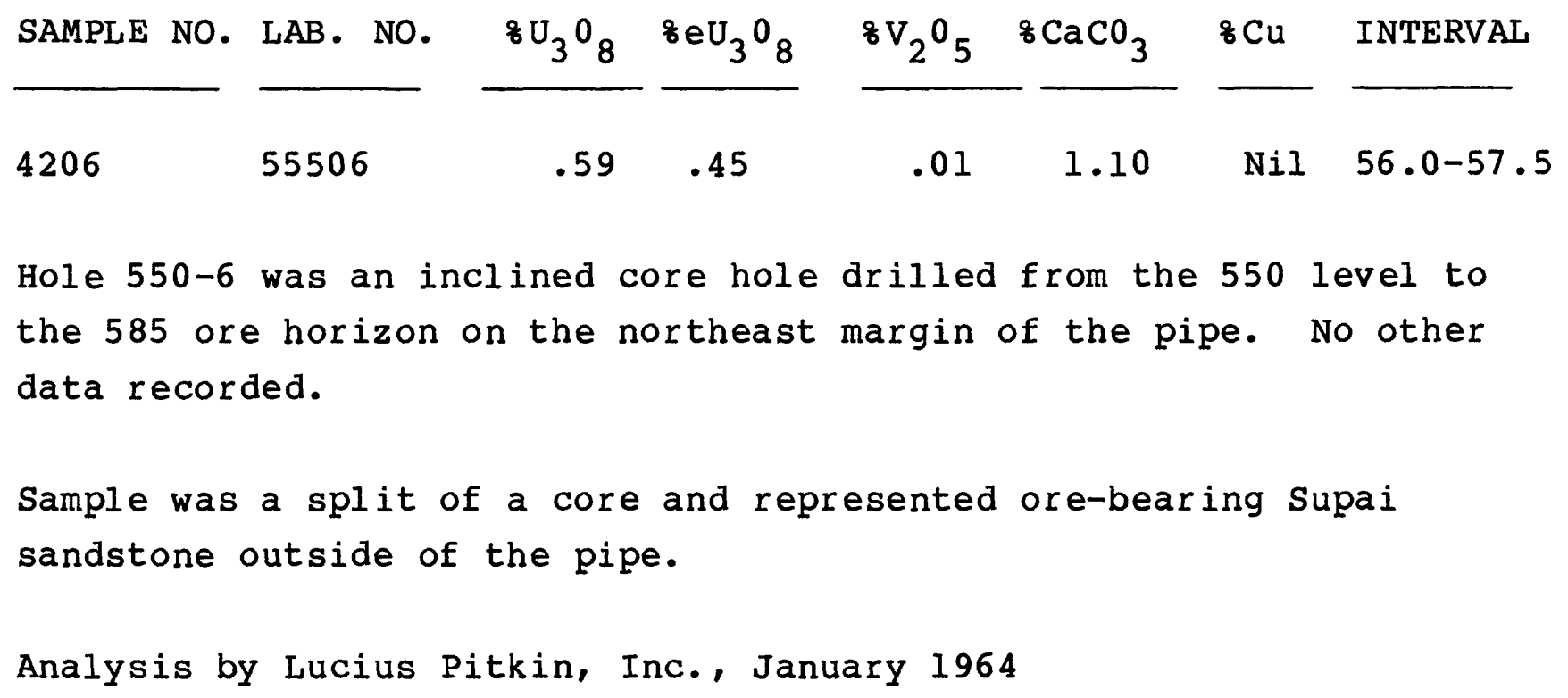




\section{ANALYTICAL DATA}

HOLE 550-12

SAMPLE NO. LAB. NO.

$\mathrm{ppmU}_{3}{ }^{0}$

$\mathrm{eU}_{3} \mathrm{O}_{8}$

${ }_{8}^{8} \mathrm{P}_{2} \mathrm{O}_{5}$

${ }_{8}^{8} \mathrm{SO}_{4}$

INTERVAL

$4343 \mathrm{~A}$

$4343 \mathrm{~B}$

$4343 \mathrm{C}$
66070

66071

66072

$\begin{array}{rr}2 & \mathrm{Nil} \\ 25 & .013 \\ 7 & \mathrm{Nil}\end{array}$

$\mathrm{Nil}$

4

$.09 \quad .01$

$52.0-52.5$

$59.0-59.7$

$.05 \quad .01 \quad 107.5-108.0$

Hole 550-12 was a horizontal core hole drilled on the 550 level. No other data recorded.

Samples are splits of core.
A- red Supai sandstone within pipe
B- gray Supai sandstone (annular ring zone)
C- red Supai sandstone outside (?) pipe

Analysis by Lucius Pitkin, Inc., September 1964 


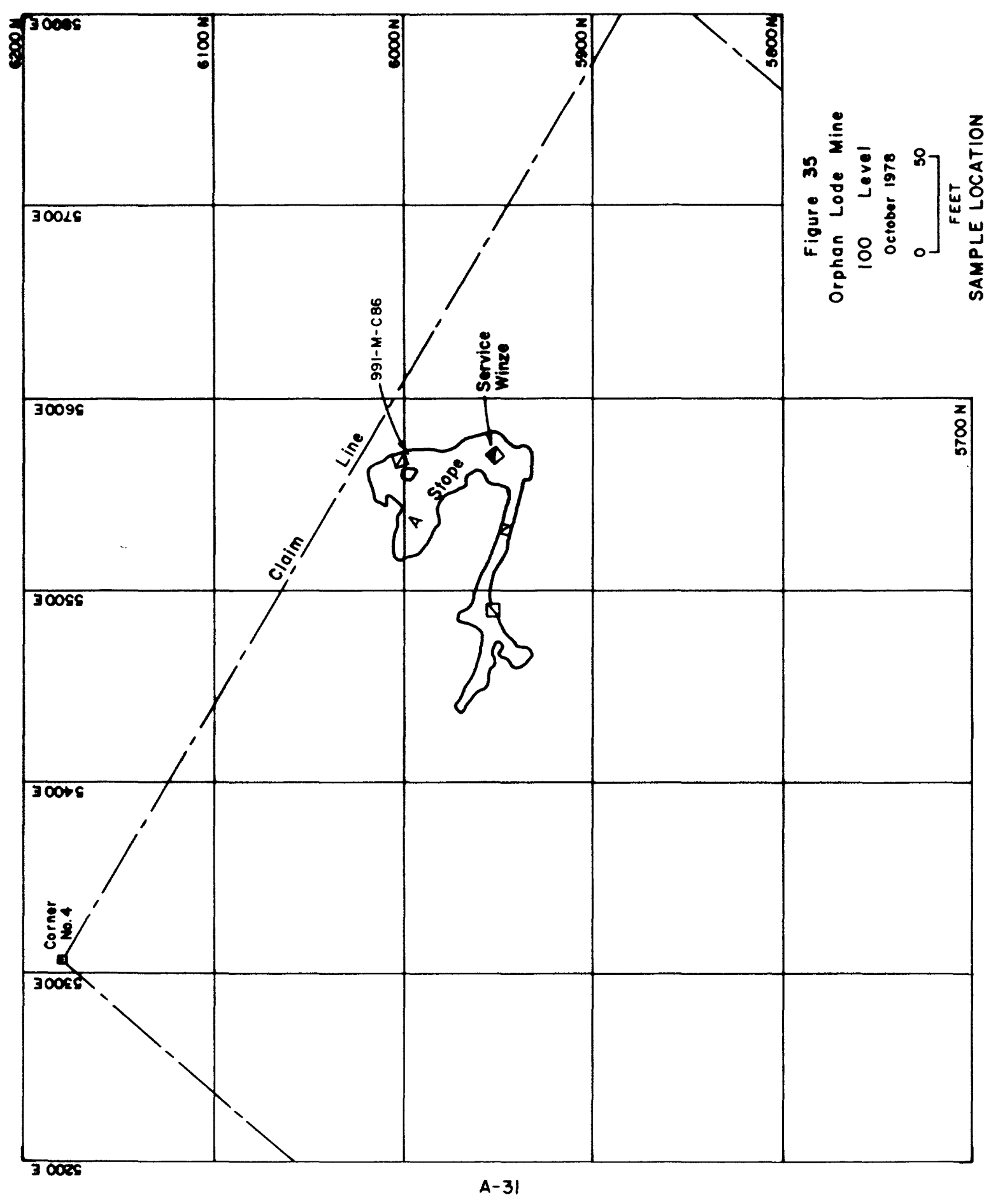




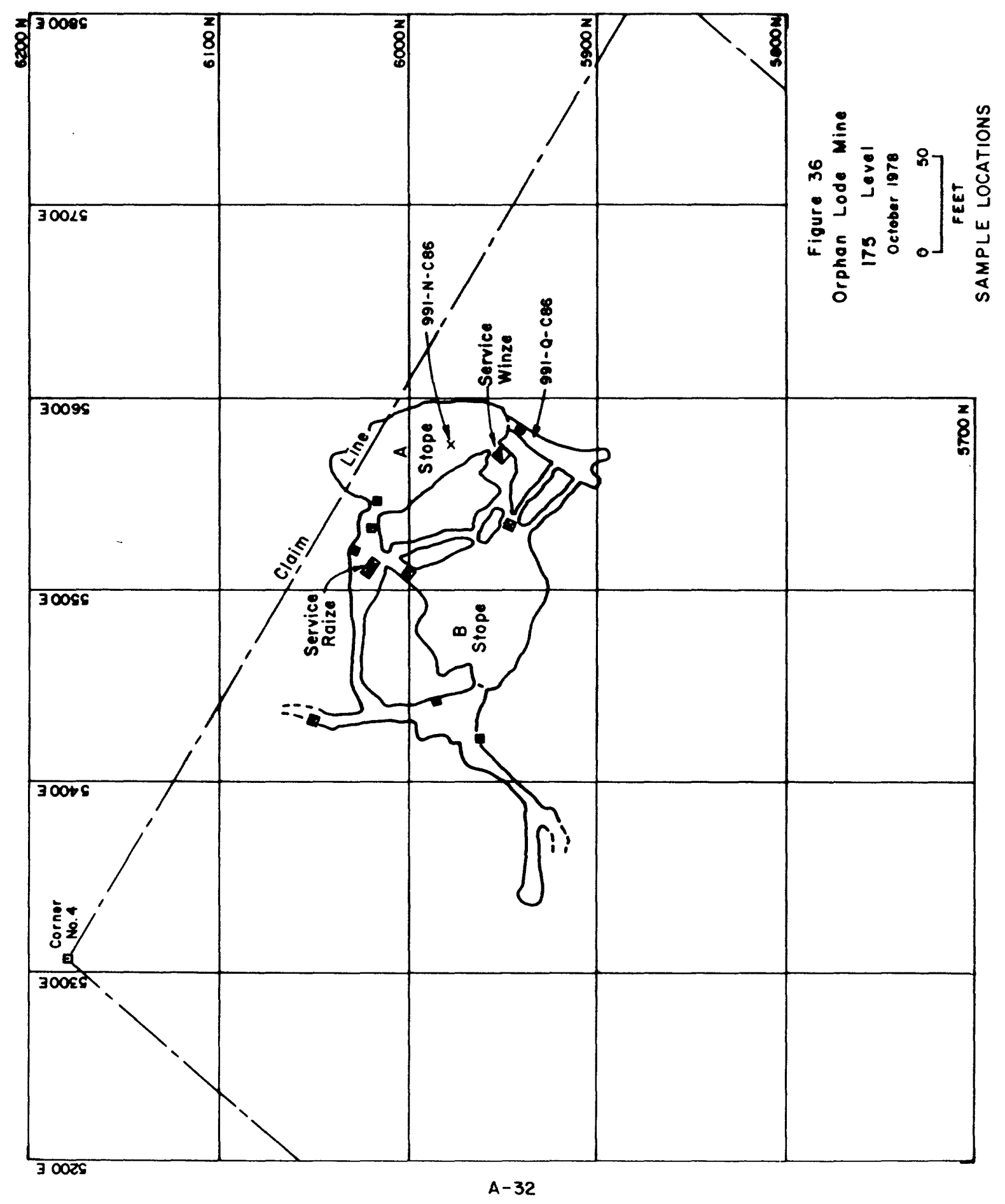




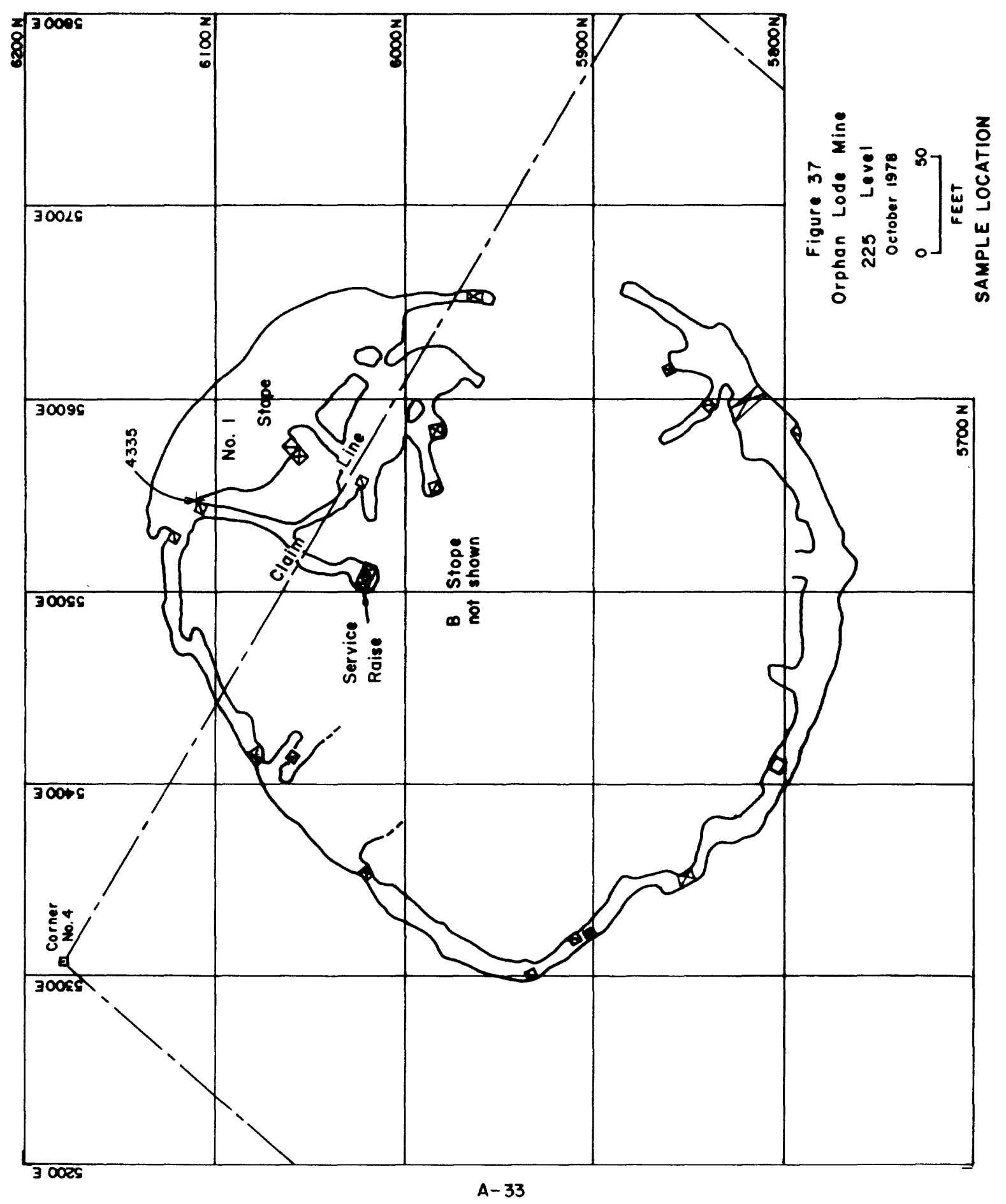




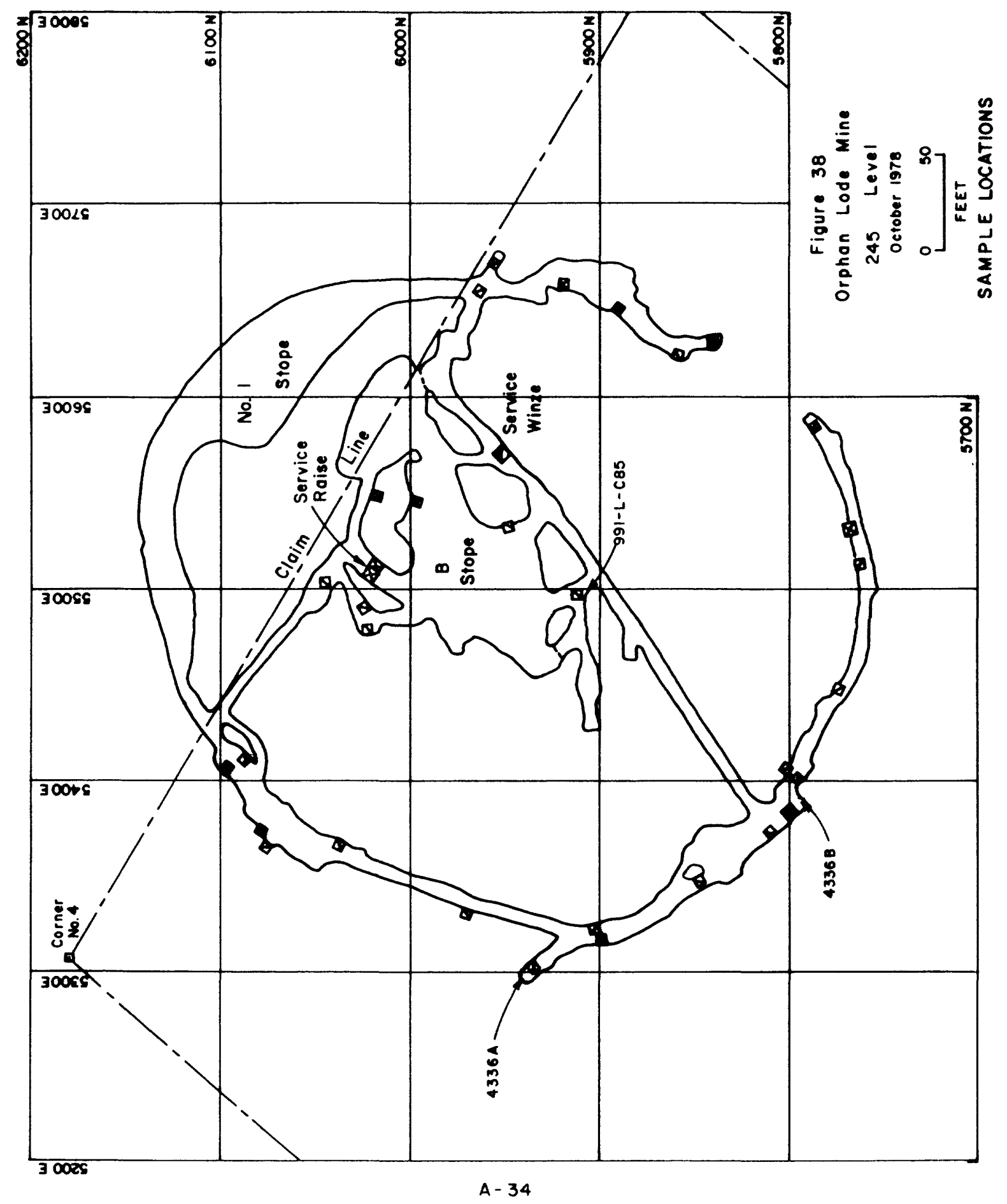




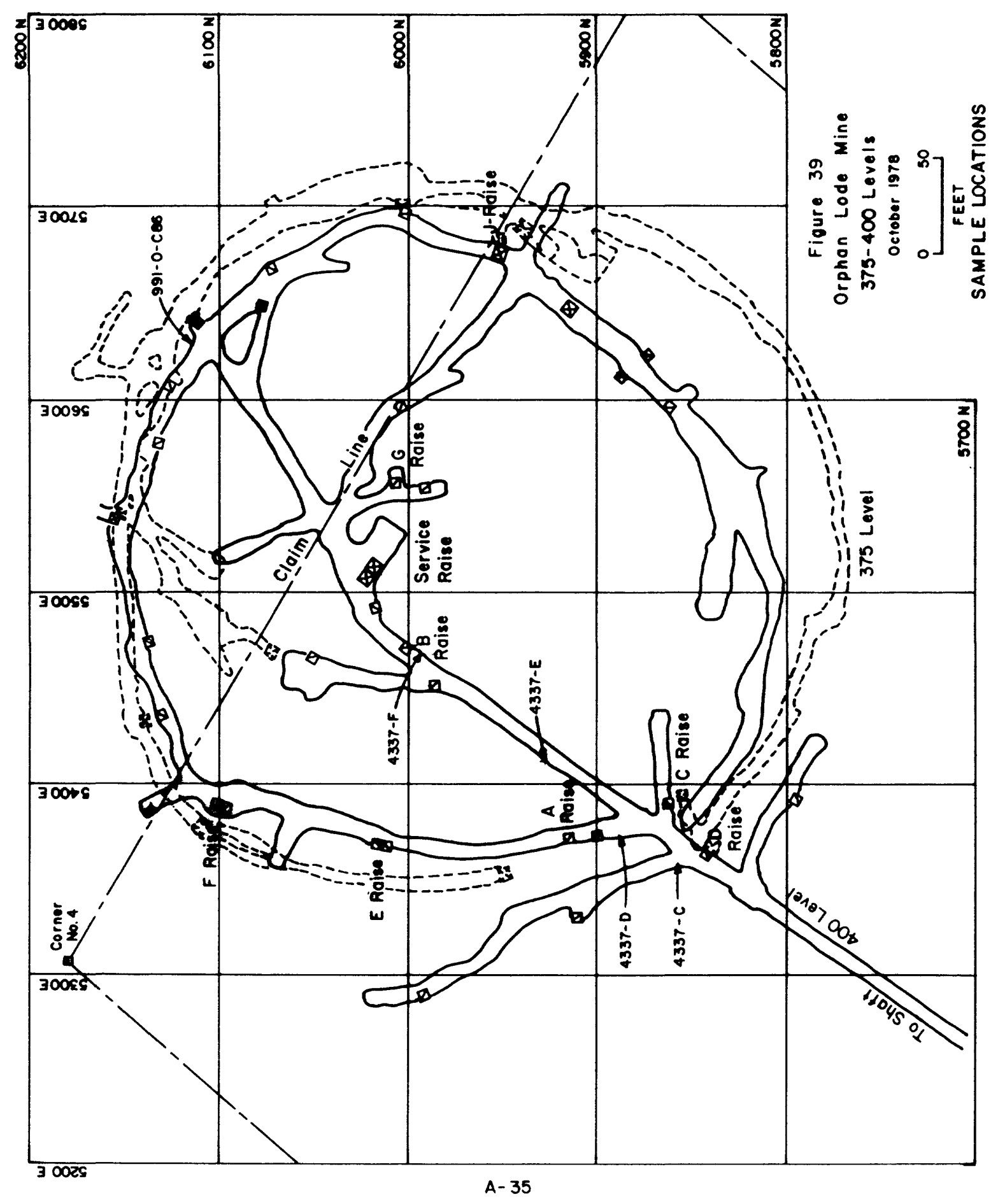

